\title{
UNIV. of
}

Tonours

LIBRAKY 



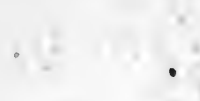

-

(2)

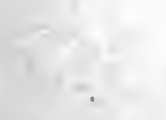


Digitized by the Internet Archive in 2007 with funding from Microsoft Corporation 
2

STATE REGULATION OF RAILROADS IN THE SOUTH 

STUDIES IN HISTORY, EOONOMIOS AND PUBLIO LAW

EDITEO BY THE FACULTY OF POLITICAL SCIENCE OF COLUMBIA UNIVERSITY

Volume LXVII]

[Number 2

Whole Number 162

\title{
STATE REGULATION OF RAILROADS IN THE SOUTH
}

\author{
BY \\ MAXWELL, FERGUSON, A. M., LL,B. \\ Sometime University Fellow in Political Science, Colwmbia Unvivervily \\ Instructor in Economics, Vasar College
}

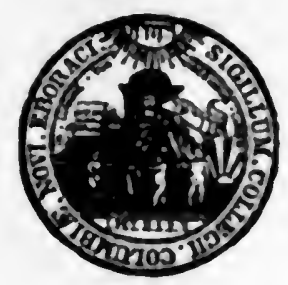

New Dork

COLUMBIA UNIVERSITY LONGMANS, GREEN \& CO., AGENTS, LONDON: P.S. KINO a SON, ItT.

1916

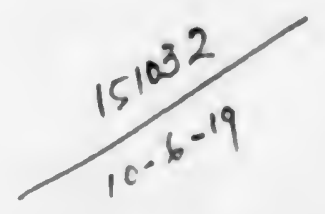


Copyright, I9I6

BY

MAXWELL FERGUSON 
TO

MY FATHER AND MOTHER 



\section{PREFACE}

In this study the author has endeavored to outline the development of state regulation of railroads in the South. with special reference to the growth and present status of regulation through the various state commissions. The chapters on Charters, Early Laws, Constitutions, and Recent General Railway Legislation are to be understood as introductory, merely, to the main body of the monograph.

That there is a need for some treatise upon the subject with which this one attempts to deal has for some time been recognized by southern scholars. But whether the publication of the pages here offered is justifiable, in view of the brief treatment, only, which the author has been able to give to this immense field, is a question concerning which he has long had the gravest doubts. He has concluded to offer the treatise in its present form, however, in the hope that students in the various colleges and universities of the South may be encouraged to take up the study of railroad regulation in each one of the southern states, aided by the brief sketches here presented, and that thus the whole field may be the sooner covered in the adequate manner to which its importance entitles it.

The reader will notice that the treatment of the subject in this study has been confined to those states, only, which lie east of the Mississippi and south of the Ohio rivers and that, accordingly, the states of Maryland, Missouri, Arkansas and Texas are not touched upon. 
This is for the reason, mainly, that the author has for some time been working in the general field of railroad transportation in the South with the hope of producing within a few years a treatise upon the more recent developments in those states which are included in the Southern Freight Classification. It is proposed, in that work, to treat of such topics as the Growth of the Principal Southern Railroad Systems, Intercorporate Relations, Special Rate Problems, and State and Federal Regulation. This present monograph is offered, then, as a small part of a larger work.

In his search for facts the writer has had to presume upon the courtesy of many officials and friends in various parts of the South whose generous coöperation has been of such assistance as to preclude a full acknowledgment in this place of his indebtedness. $\mathrm{He}$ is under special obligation, however, to Professor Charles Lee Raper, of the University of North Carolina, for the suggestion of the subject of this study, for sound criticism of the more important drafts and for continued advice and encouragement; and to Professor W. C. Mitchell, for his careful reading of the manuscript and galley proof. To Professor Edwin R. A. Seligman, especial acknowledgments are due, and are here gratefully tendered, both for his kindness in revising and preparing this study for publication, and for helpful suggestions and stimulating criticism throughout the whole of the author's graduate course. Finally, to all the remaining members of the Faculty of Political Science under whom he has studied, he wishes to extend his gratitude for the widened outlook upon human activity which they have steadily set before him.

New York City, igi6.

Maxwell Ferguson. 


\title{
TABLE OF CONTENTS
}

\author{
PART I \\ INTRODUCTION \\ CHAPTER I
}

Cinarters

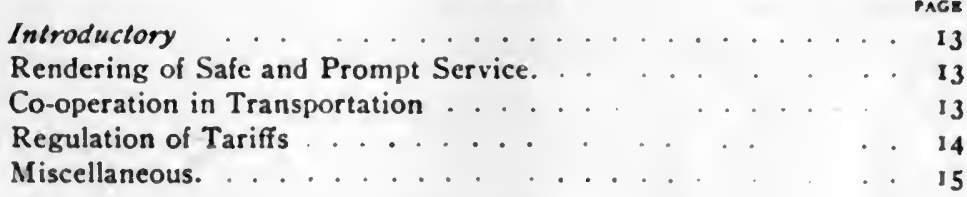

CHAPTER II

Early General Laws

Virginia Law of 1837 . . . . . . . . . . . . . 17

North Carolina Law of 1872 . . . . . . . . . . . . . 19

Conclusions. . . . . . . . . . . . . . 20

CHAPTER III

Constitutional Provisions Affecting Railronds

Incorporation. . . . . . . . 2I

Public Aid . . . . . . . . . . . . . . 22

Direct Regulation and Control . . . . . . . . . . 22

CHAPTER IV

RFefent General Railiway Legislation

In General . . . . . . . . . . . . . . 26

Conditions of Incorporation . . . . . . . . . 27

Construction, Maintenance and Operation ......... 31

Regulation of Traftic . . . . . . . . . . 36

Rates .... . . . . . . . . . . 37

Reports ................. . . 40

319] 0 
PART II

PAGB

\section{Commission Regulation \\ CHAPTER V \\ Outline of Commission Development}

Early Agencies of Supervision. . . . . . . . . . . . 4 4

Establishment of the Commissions . . . . . . . . . 43

The "Crusade" against the Railroads. . . . . . . . . . 5I

\section{CHAPTER VI}

\section{VIRGINIA}

The Advisory Commission . . . . . . . . . . . 55

The Creation of the Corporation Commission . . . . . . . 64

The Work of the Corporation Commission. . . . . . . . . . 69

CHAPTER VII

South Carolina

The Advisory Commission . . . . . . . . . . . 85

The Mandatory Commission . . . . . . . . . . 87

\section{CHAPTER VIII}

\section{Georgra}

The Commission to its Recrganization in $1907 \ldots \ldots$. . . . . 95

The Commission since $1907 \ldots \ldots \ldots$. . . . . . . 104

\section{CHAPTER IX}

\section{KENTUCKY}

The Advisory Commission . . . . . . . . . . . . . 108

The Commission under the McChord Act of $1900 . \ldots . . . .$. II5

CHAPTER X

\section{Alabama}

The Advisory Commission ... . . . . . . . . 128

The Mandatory Commission ... . . . . . . . . . 134

\section{CHAPTER XI}

TenNessee

The First Mandatory Commission. . . . . . . . . . . . 139

The Second Mandatory Commission. . . . . . . . . . 143 
Mississip PI

\section{CHAPTER XIII}

\section{Florida}

The First Mandatory Commission . . . . . . . . . . . 153

The Second Mandatory Commission. . . . . . . . . 157

\section{CHAPTER XIV}

Norti Carolina

The Fight for a Commission. . . . . . . . . . . . . . 164

The Railroad Commission. . . . . . . . . . . . . . 168

The Corporation Commission . . . . . . . . . . . 170

The Virginia-North Carolina Cities Controversy . . . . . . . 174

\section{CHAPTER XV}

Louisiana

\section{CHAPTER XVI}

West VIRGINIA ...

CHAPTER XVII

\section{Summary of Present Commission Laws}

Jurisdiction. . . . . . . . . . . . . . . . 190

Organization ........................... 191

Duties ................... . . 193

Powers..................... . . 194

Method of Procedure ............... 195

\section{CHAPTER XVIII}

\section{Survey of the Present Commission Situation}

Selection of the Commissioners . . . . . . . . . . . . 197

Term of Office .................. . . 198

Technical Fitness. . . . . . . . . . . . . 199

Appropriation for Expenses............. 201

Valuation of Railroad Properties. . . . . . . . . . . . . 204

Accounts. . . . . . . . . . . . . 205

Regulation of Capitalization. . . . . . . . . . 205 
12

TABLE OF CONTENTS

$\left[3^{22}\right.$

PAGE

Rates. . . . . . . . . . . . . . 207

Court Review. . . . . . . . . . . . . . 212

CHAPTER XIX

Conclusion . . . . . . . . . . . . . . . . . 218

APPENDIX

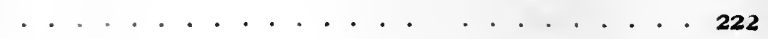




\section{CHAPTER I}

\section{Charters}

\section{Introductory}

ThE chief objects which the southern states appear to have had in mind in connection with railway regulation were generally the following: the regulation of the tariffs of the railroads; the coopperation of the different companies in the transportation of freight and passengers; and the rendering of safe and prompt service to the public. The early charters were very loosely drawn; but as mistakes came to light in the course of time the tendency developed of putting more and more exacting restrictions upon the operation of the carriers. It will not be out of place here to attempt a rapid summary of the ends that were sought to be accomplished.

\section{Rendering of Safe and Prompt Serice}

As stated in a charter granted by North Carolina in 1837 , the customary rule was that the company "shall at all times furnish and keep in good repair the necessary carriages and other requisites for the safe and convenient transportation of persons and property."

\section{Coöperation in Transportation}

Connections and Crossings. Charters very often prescribed that the railroads were to allow each other's tracks to unite or intersect wherever reasonable and feasible, and

1 Acts, 1837 , ch. $x 1$, sec. xxviii. 
this feature became more common in later charters, as the petty state jealousies wore away. ${ }^{1}$

Consolidation. There was very little mention of this topic in the earlier charters. ${ }^{2}$ Whatever tendency there was appears to have been in favor of the authorization of consolidation. ${ }^{8}$

The Leasing and Operation of Parallel or Competing Lines. This was a power frequently conferred in the charters, roughly, antedating the Civil War. With the development of evils such as extortion this power came to be more and more explicitly denied to the companies."

The Construction of Parallel Lines. Express prohibitions appear rather early in the charters of all the states in regard to such construction. ${ }^{5}$ It is greatly to be deplored that prohibitions of this nature were not more numerous and stringent.

\section{The Regulation of Tariffs}

In General. The commonest provision was such as that in an early Florida charter where the right was conferred upon the company to "demand and receive such prices and sums for transportation-as may be from time to time authorized and fixed by the by-laws of said company." Very often it was provided that any excess over a certain annual rate of profit-usually from fifteen to twenty per cent-should be paid into the internal improvement fund. ${ }^{7}$

1 Laws of Virginia, 1836 , ch. iv, sec. xxvi.

"Meyer, Railway Legislation in the United States, p. 77.

'E. g., Laws of Kentucky, 1833, ch. ccvi, sec. xix.

- Meyer, op. cit., p. 77.

'Laws of Louisiana, 1831, no. Iv, sec. vi; Laws of Georgia, 1839, p. 104; ibid., 1835. p. 192; Laws of Kentucky, 1833, ch. ccvi, sec. xx.

- Laws of Florida, 1850-51, ch. cccxvii, sec. xiv.

'/bid., ch. cccxvii, sec. xiv; cf. Laws of West Virginia, 1868, ch. lii, sec. vi. 
In many charters there was no reference at all to the tolls or rates to be charged. ${ }^{2}$ In some cases rates were fixed by reference to those prescribed in charters granted previously by the same state or by other states. ${ }^{2}$

Marimum Rates. Maximum rate provisions were plentiful in both the early and later charters. But in nearly every instance the maximum was placed so high as virtually to deprive those provisions of most of their importance. ${ }^{3}$

Publicity of Rates. This was a matter seldom dealt with. Wherever a provision appeared it provided, usually, for the publishing of rates in one or more newspapers within a certain period after the action of the directors, and forbade their increase during the period for which they were established."

Discrimination. There are very few references in the early charters to this subject. The most notable clause occurs in a charter granted by North Carolina in 1837 , wherein it is stated that the company "shall give no undue preference to the property of one person over that of another, but as far as practicable shall carry each in the order of time in which it shall be delivered or offered for transportation." s

\section{Miscellaneous}

Powers Reserved to the Legislature. This was a matter not treated at all in the majority of charters. Whatever provisions there were referred, as a rule, to the right of the legislature either to regulate the charges for transportation

'Laws of Georgia, 1835, p. 196.

2 Meyer, op. cit., p. 62.

3 Ibid., pp. 58-62; Laws of Kentucky, 1833, ch. cevi, sec. xx; Laws of Virginia, 1836 , ch. cxi, sec. xlvi.

- Meyer, op. cit., pp. 62-63; Laws of Louisiana, 1831, no. Iv, sec. ix.

s Laws of North Carolina, 1837, ch. xl, sec. xxix; Laws of West Virginia, 1866, ch. exxxi, sec. vii. 
or to purchase the railroad after the lapse of a certain number of years. ${ }^{2}$

State Participation in Construction. The charters of all the states afford numerous examples of this practise.

Limitations on the Life of Charters. Most of the charters failed to include a provision on this point. The limit. wherever one was set, was rarely beyond forty years. ${ }^{2}$

Limitations as to Taxation. In order to encourage the construction of railways it was a general practise in the South narrowly to confine the authority of the state in the matter of taxation, and even to exempt railroad property altogether from taxation for the early period of the corporation's life. ${ }^{3}$

1 Meyer, op. cit., pp. 67-68.

Ibid., pp. 69-70.

"Meyer, op. cit., pp. 70-7I ; Laws of Louisiana, 183r, no. lv, sec. ix; Laws of Kentucky, 1833, ch. ccvi, sec. xx; Laws of Florida, 1854-55, ch. dex, sec. xviii. 


\section{CHAPTER II}

\section{Early General Laivs}

The first fundamental general laws in the eastern and north central states appeared, roughly, in the decade $1835^{-}$ 45, whereas in the South such laws did not make their appearance, in the main, until somewhat later. ${ }^{2}$ Two instances are here given, - - one of a statute enacted in the thirties, and the other of a law passed a few years after the conclusion of the Civil War.

The Virginia law of 1837 -the first general law enacted in the South-did away, in the first place, with the requirement of a legislative charter for each company lauuched, under which previously only strong interests had been able to carry their bills through the assembly. Certain general regulations were to be deemed a part of all subsequent charters incorporating railroad companies, " to the same effect as if the same were expressly re-enacted in reference to any such charter or act, except so far as such charter or act may otherwise provide."

It sought, in the second place, to safeguard the property and tolls of the railroads by a provision to the effect that any part of any charter or act of incorporation "granted agreeably to the provisions of this act "might be altered, modified, or repealed by any future legislation, except that no law was to be passed taking from a company its works or property without the making of just compensation, or changing its rate of compensation without its consent. And

'Meyer, op. cit., p. 95. 
to make sure that the railroads should not be interfered with too greatly in their laudable desire to enrich their stockholders, this act provided that no future law should so reduce the rate of compensation of any company chartered under the act as to prevent dividends of fifteen per cent per annum within thirty years from the time when the first dividends from profits should be declared, or as to prevent dividends of twelve per cent per annum after the expiration of those thirty years and before fifty years from the same time, or as to prevent dividends of ten per cent per annum after the said fifty years. Of course, a legislature has no right to bind future legislatures in any such manner as this, as the United States Supreme Court has often enough decided. And yet this anomalous provision was re-enacted into later codes, was never challenged by subsequent legislatures, and was only overthrown, after the lapse of seventy years, by the energetic action of the corporation commission in the memorable struggle over the two-cent maximum passenger fare prescribed by the commission in 1907 for the strongest railroads in Virginia.

A third and very important provision of this act had to do with the additional duties which were now laid upon the board of public works. The board was ordered to obtain from each railroad in which the commonwealth was interested as a stockholder or creditor, or which was wholly within the state, an annual report, showing the amount of capital stock, the gross receipts, and the net loss or profit for the year. As soon as a report indicated that the original cost of the road, together with six per cent interest, had been reimbursed to the stockholders, the board was to prescribe such tariffs for the road as would return to the stockholders six per cent dividends annually. A provision like this could be of little or no effect, for the reason that when a railroad earns more income than it lawfully has the 
right to, it finds it very easy to dispose of the surplus over and above the legal rate of dividends in the payment of higher salaries and the like. The Virginia railroads, accordingly, so managed their finances that the board of public works never had a chance throughout its long career of eighty-six years to exercise its rate-making function. ${ }^{2}$

A far better example is the first general railroad law of North Carolina, enacted in 1872,2 and covering somewhat more than thirty pages. First, the rules for the formation of railroad companies were laid down. Any number of persons, it was provided, - not less than twenty-five (an unusually high number for the South) - might form a company for the purpose of constructing, maintaining, and operating a railroad for public use. The articles of association were to state the name of the company, the years of its corporate life, the route (in detail), the amount of the capital stock, and the names and residences of the directors (sec. i). Second, the chief powers of companies were enumerated; namely, to intersect and unite with other railroads at any point on the route; to regulate the time and the manner in which passengers and property should be transported; to fix the charges for such transportation services (with the exception that passenger fares were not to exceed a maximum rate of five cents a mile); and to borrow money for the completion and operation of the road (sec. xxix). Third, provision was made for the rendering of annual reports to the governor by all corporations formed under this act, such reports to embrace one hundred and two items and to cover, principally, the amount of capital and indebtedness, the cost of the road and equipment, its char-

1 Acts of 1836-1837, ch. cxviii; in particular, secs, xxiii and xxvi.

Laws, 1871-72, ch. cxxxviii. 
acteristics, the transportation services of the year, the expenses of maintenance, and gross and net earnings (sec. xxxi). Fourth, the legislature reserved the right to reduce the rate of freight, fare "or other profits" in all cases except where such reduction would decrease net profits to less than ten per cent per annum on the capital actually invested (sec. xxxiii). Finally, consolidation or merger with continuing lines was permitted, while expressly forbidden in the case of parallel or competing lines (secs. lviii and $l x v$ ).

In brief, this act contained most of the principles and provisions embraced in the multitude of special charters hitherto granted. Like the general laws of other states, it may be said to have furnished the point of departure for all subsequent legislation on the subject of railways. And again, like those other laws, it barely touched upon the vital questions of extortionate charges and unjust discrimination which were soon to awaken the people to a truer conception of the relation of the railroads to the State. 


\section{CHAPTER III}

\section{Constitutional Provisions Affecting Rallroads}

\section{Incorporation}

IN most of the southern states the legislature may not alter or amend the charter of an existing corporation, or pass a general or special law for its benefit except upon the condition that the corporation in question will thereafter hold its charter subject to the constitution." This is to bring to terms sooner or later those corporations whose charters were granted decades ago in the period when legislators allowed charters to be very loosely drawn.

Corporations are prohibited from incorporating under special laws in Alabama, Kentucky, Louisiana, South Carolina and Virginia. ${ }^{3}$

Most of the states specifically declare that corporations may be formed under general laws only.

In Alabama, Georgia, Kentucky, Louisiana, Mississippi, North Carolina, South Carolina and Virginia the right is reserved to the state to amend or revoke any charter the

I Ala., art. xii, sec. cexxxi; Ga., art. iv, sec. xi; Ky., sec. cxc; La., sec. celxii; Miss., art. vii, sec. clxxix; S. C., srt. ix, sec. xvii; Va., art. xii, sec. clviii.

2 Ala., art. iv, sec. ciii; Ky., sec. lix : J.a., sec. xlviii; S. C., art. ix, sec. ii; Va., art. iv, sec. Ixiii, and art. xii, sec. cliv.

sla., art. xii, sec, cexxix: Fla., art. iii, sec. xxv: La., sec. xlviii : Miss., art. vii, sec. clxxviii; Tenn., art. xi, sec. viii; Va., art. iv, sec. lxiii, and art. xii. sec. cliv: W. Va., art. xi. sec. i. 
operation of which, in the opinion of the legislature, may be injurious to its citizens. ${ }^{1}$

\section{Public Aid}

In every state except North Carolina the loaning of the public credit and public subscriptions in stock are absolutely prohibited. Loans of credit without a referendum are also forbidden in North Carolina, except for railroads not completed at the time of the adoption of the constitution, or for those in which the state has a direct pecuniary interest. ${ }^{2}$

\section{Direct Regulation and Control}

As to connections and crossings, the rule in over half the states is that the railroads must allow each other's tracks to unite or intersect wherever reasonable and feasible, and must receive and transport each other's passengers, tonnage and cars without delay or discrimination. ${ }^{3}$

To the subject of consolidation but little attention has been devoted. In Mississippi and South Carolina the consolidation of a domestic with a foreign road (i. e. a road incorporated in some other state) is permitted only in case the consolidated company becomes a domestic corporation. ${ }^{4}$ Kentucky and West Virginia go further and declare that no road may consolidate its stock, property or franchise with a competing line. ${ }^{5}$ In Virginia no company has the exclu-

1 Ala., art. xii, secs. cexxix, cexxxviii; Ga., art. i, sec. cxi; Ky., sec. ccv; La., sec. cclxii; Miss., art. vii, sec. clxxviii; N. C., sec. cxxxiii.

${ }^{2}$ Ala., art. iv, sec. xciii ; Fla., art. ix, sec. $x$; Ga., art. vii, sec. v; Ky., sec. clxxvii; La., sec. Iviii ; Miss., art. xiv, sec. cclviii; N. C., art. v, sec. iv; S. C., art. x, sec. vi; Tenn., art. ii, sec. xxxi; Va., art. xiii, sec. clxxxv; W. Va., art. $x$, sec. vi.

s Ala., art. xii, sec. cexlii; Ky., secs. cexiii, ccxvi-ccxvii; La., secs. celxxi, cclxxxiv; Miss., art. vii, sec. clxxxiv; S. C., art. ix, sec. vi; Va., art. xii, sec. clxvi.

- Miss., art. vii, sec. cxcrii ; S. C., art. ix, sec. viii.

- Ky., sec. cci; W. Va., art. xi, sec. xi. 
sive right, by law, to build a parallel line. ${ }^{2}$ South Carolina prohibits all attempts to accomplish objects forbidden by the state constitution through subterfuges, such as holding companies, stock control, and the like. ${ }^{2}$ Pooling is forbidden in Kentucky and Mississippi. ${ }^{3}$ Kentucky is the only commonwealth that prohibits railroad construction by the state.

Virginia and West Virginia provide for the rendering of annual reports by the railroads to the state. ${ }^{5}$

The all-important subject of rates is treated at more or less length in all of the constitutions except those of North Carolina and Teunessee. (a) Discriminations in charges (as well as in facilities) for the transportation of freight or passengers are forbidden in Alabama, Georgia, Kentucky, Louisiana, Mississippi, South Carolina and West Virginia." In Georgia and Kentucky the power and duty to prevent discrimination is vested directly in the legislature.

Passes or reduced rates for public officers are prohibited in six of the states. ${ }^{8}$ The ordinary exceptions are made of course, as, for instance, in the case of the railroad commissioners in Louisiana, Mississippi and Virginia." There are "long and short haul" provisions in Kentucky,

1 Va., art. xii, sec, clxvi.

S. C., art. ix, sec. xix.

Ky., sec. cexiv; Miss., art. vii, sec. cxcvii.

- Ky., sec, clxxvii.

- Va., art. xiii, sec. clxxix; W. Va., art. xi, sec. vii.

- Ala., art. xii, sec. ccxlv; Ga., art. iv, sec. ii; Ky., secs. cexiii-cexv ; La., sec. cclxxi; Miss., art. vii, sec. clxxxiv; S. C., art. ix, sec. v: W. Va., art. xi, sec. ix.

' Ga., art. iv, sec. ii; Ky., sec. excri.

S Ala., art. xii, sec. cexliv; Fla., art. xvi, sec. xxxi; Ky., sec. excvii; La., sec. exci; Miss., art. vii, sec. clxxxviii; Va., art. xii, sec. clxi.

- La., sec. celxxxvii; Miss., art. vii, sec. clxxxviii ; Va., art. xii, sec. clxi. 
Louisiana and South Carolina, regarding which, also, the railroad conmissioners may make exceptions, if in their opinion advisable. ${ }^{1}$ (d) In four states the legislature is given full power to regulate and control passenger and freight rates. ${ }^{2}$ In addition the legislatures of Louisiana and South Carolina may regulate and change the order and rules promulgated by the railroad commissions of those states. $^{3}$ (e) In only one state-West Virginia-is power conferred upon the legislature to establish maximum freight and passenger rates. ${ }^{4}$

The topic of railroad commissions receives particular attention in the constitutions of Kentucky, Louisiana and Virginia. Such matters as the creation of the commission; the qualifications and disqualifications, number, term of office, manner of selection, compensation, causes and manner of removal and so on, of the commissioners; regular and special hearings; the taking of testimony; procedure; and annual reports by the carriers are there regulated. ${ }^{5}$ Louisiana and Virginia confer upon their commissions the power to make reasonable and just rates for the corporations under their jurisdiction. ${ }^{\circ}$ Kentucky, South Carolina and Virginia authorize their commissions to disregard the "long and short haul" provisions of their respective constitutions whenever it is necessary to protect the commerce of the state. ${ }^{7}$ In Virginia, also, the plan of a proposed issue of

${ }^{1}$ Ky., sec. cexviii ; La., sec. cclxxxiv; S. C., art. ix, sec. v.

=Ala., art. xii, sec. cexliii; Ga., art. iv, sec. ii; Miss., art. vii, sec. clexxvi; W. Va., art. xi, sec. ix.

"La., sec. celxxxiv; S. C., art. ix, sec. v.

4 W. Va., art. xi, sec. ix.

${ }^{5} \mathrm{Ky}$., sec. ccix; La., sces. cexvii, cexxii, cclxxxiii-cclxxxiv, cclxxxviicclxxxix; Va., art. iv, sec. liv; art. xii, secs. clv-clvii. See also S. C., art. ix, secs. v, xiv.

${ }^{B}$ La., sec. celxxxiv; Va., art. xii, sec. clvi-b.

${ }^{7}$ Ky., sec. cexviii; S. C., art. ix, sec. v; Va., art. xii, sec. clx. 
stocks and bonds must first be submitted in detail to the commission, and charters and licenses to domestic or foreign corporations may be issued only through this same body. ${ }^{2}$

In every one of the constitutions there is a noticeable absence of provisions in regard to the significant questions of accounting and physical valuation.

Va., art. xii, sec. clvi. 


\section{CHAPTER IV}

\section{Recent General Railway Legislation ${ }^{1}$}

\section{In General}

The first general characterization that may be made is that in spite of the fact that the laws regarding railroads passed during recent decades in the South are extremely voluminous, they are nevertheless disappointingly incomplete. "Repetitions, redundancies, elaborations, and conflicting passages " have accounted in great measure for their volume, so that important topics, like pooling and employees, have unfortunately received but scant attention. Secondly, there has been a growing tendency to provide for the incorporation of railroads only under a form of law which is applicable to other corporations than railroads. In the third place, a movement has been steadily gathering force providing for the increasing of the powers of commissions already established and for the conferring of continually larger authority upon new commissions as they are created. Fourthly, a marked increase may be noted, especially in the past decade, in acts designed to regulate the service of public carriers and to secure the greater safety of the traveling public. Finally, there has been an unfortunate drift, culminating in the Kentucky legis-

${ }^{1}$ See House Documents, vol. 73, 58th Congress, 2d session, for an exhaustive compilation of laws passed by all the states in the twelve years 1890-1902. This chapter is largely adapted from that compilation, and references are cited in the cases, only, of important laws enacted since 1902 . 
lation of 1914, toward the substitution of state control over rates and fares by means of legislative enactments, such as maximum fare laws, for the authority exercised by the commissions. States which apparently accepted the doctrine of rate control through expert commissions when they conferred extensive rate-making powers upon those commissions have seen fit to disregard that principle in the promulgation by legislative enactment of maximum freight and passenger fares. "The wisdom of fixing fares by a sweeping and inflexible statute instead of through an expert commission " has proved not alone "questionable" in the South, but subversive, in fact, of the best interests of both carriers and people. Experience has amply demonstrated that a large body, like a legislature, cannot efficiently cope with the rate situation in the South, and that the first essential of effective and intelligent control over rates and fares is the unhampered activity of a small, efficient, and impartial administrative board.

\section{Conditions of Incorporation}

1. Organization. In every constitution there is a provision which prohibits the incorporation of railroad companies under special or local acts; and in a few of the states this prohibition is likewise found in the general laws. The minimum subscription necessary before the articles of incorporation may be filed with the secretary of state varies from $\$ 250$ per mile of railroad in Kentucky to $\$ 1,000$ in North Carolina, with a minimum provision in a couple of states, as in Alabama, of ten per cent of the whole. Minimum cash payments which must be made on the stock subscribed for before the articles may be filed run from two per cent in Alabama to twenty per cent in Kentucky and South Carolina. The minimum number of incorporators is one in Mississippi, three in Florida and South Carolina, five in 
Tennessee and West Virginia, six in Louisiana and North Carolina, seven in Alabama, Kentucky and Virginia, and ten in Georgia. The limit of the corporation's duration, where such has been fixed by the states, is from fifty years in West Virginia, sixty years in North Carolina, ninety-nine years in Louisiana and Mississippi to one hundred and one years in Georgia, with the privilege, generally, of further renewal. As to the determination of route, the laws of all the southern states are much more precise than they were in the first stages of regulation. "Under early railway methods the route was very indefinitely indicated, the best of all descriptions being frequently contained in that clause in the charter naming the termini of the road." In some charters, also, one or more intermediate points were designated, but in only a few was "the entire route described with sufficient definiteness to enable one to tell beforehand exactly where the railway would be constructed." ' All this is now changed. In each state a map, describing the proposed route in detail, must be submitted to the proper authority. Finally, each state reserves to itself the right to alter, amend, or repeal the franchise of any railroad corporation, whether organized under special or under general laws.

2. Stock and Stockholders. Provisions are numerous in regard to such matters as the minimum amount of capital stock, the issuing of stock for property or services, the par value of shares ( $\$ 100$ in each state), the liability of stockholders, cumulative voting of stockholders for directors (in about half the states), stockholders' meetings, the keeping of stock books and stock transfer books, the opening of books, records, etc. to stockholders, the declaration of dividends, and the like.

${ }^{2} C f$. Meyer, op. cit., for an admirable description of early methods of incorporation. 
3. Officers and Directors. The qualifications, number, length of term, meetings, reports to stockholders, and the liabilities of directors are some of the topics dealt with under this head.

4. Liability to Public Control. At one time or another the legislatures of all the states have enacted laws for the fixing of maximum rates, the prevention of extortion and discrimination, etc. In fact, the constitutions of many of the commonwealths require the legislatures so to act. A remarkable omission is that no southern state, so far as can be discovered,- - unlike several states in the north, such as Massachusetts, Pennsylvania and Vermont-has reserved the right to purchase any railroad which it has chartered.

5. Forfeiture. The usual provisions are that the railroad corporation must begin work within a certain number of years after incorporation (generally two), and must complete a certain number of miles by a certain time to avoid forfeiture of charter.

6. Powers Relative to Management. The usual powers bestowed upon the railroads in this connection are those of regulating the time, the manner, and the charges for transportation: but in recent years the authority of the state railroad commissions has been so increased that, save in Kentucky, the roads have been confined, merely, to the regulating of the time of transportation, and in that particular, even, in a couple of the southern states, - notably Florida-their powers have been swept away.

7. Powers Relative to Construction. The railroads have the power to unite their tracks with those of other roads crossing their own; to connect at the state line with railroads of other states; to carry their tracks over or under highways; and to build extensions. A notable provision in three of the states-Tennessee, Virginia, and West Virginia-is designed to prevent one railroad company from holding 
the exclusive possession of a narrow mountain pass or canyon. If the pass or canyon is too narrow to permit the laying of more than one track, the road which has first built through it must allow the joint use of that track to any other railroad desiring to extend its line through the canyon or pass.

8. Powers Relative to Consolidation. According to the usual provisions, any railroad may lease, purchase, merge with, consolidate with, or make operating contracts with any other railroad, except that the consolidation of parallel lines is forbidden. In Mississippi, the consent of the railroad commission is necessary in case of consolidation; in Virginia, a railroad company may not purchase the stock of any other corporation, save with the consent of the legislature or of a competent court; while in West Virginia the consolidation of parallel lines is permitted with the consent of the legislature, and, in Florida, with that of the commission. A peculiar provision in Georgia is to the effect that no line may be built parallel to the Atlantic and Western Railroad, so long as that road remains the property of the state. ${ }^{1}$ Nevertheless the facts in the case "clearly and unequivocally reveal a wide disparity between the provisions of the law and the facts of railway development." When there are taken into account " the steady and uninterrupted consolidations which have absorbed line after line, on the one hand, and ... duplication of laws attempting to govern these, on the other hand, the conclusion is irresistible that somehow these laws did not accomplish the purposes for which they were enacted." 2 The truth is that the southern railroads, like those of other parts of the country, by the use of holding companies, voluntary associations, gentlemen's agree-

1 Laws of Georgia, 1915, no. Ixxxvii.

2 Meyer, op. cit., p. 139. 
ments and similar devices, were easily enabled to elude the slow-moving machinery of the law.

9. The Issue of Securities. Most of the southern states have contented themselves with the forbidding of fictitious issues of bonds, and have paid but scant attention to the control of stock issues. Georgia has gone much further than any other state, and by the provisions of the act of 1907 has conferred extensive powers upon its railroad commission in the matter of stocks and bonds. There is an interesting statute in Virginia according to which no railroad may borrow money until the stock subscribed for has been paid up and the proceeds have been expended. But it may borrow an amount not exceeding the stock unsubscribed for, and make such bonds convertible into stock.

\section{Construction, Maintenance and Operation}

I. Roadway. The width of the right of way has been limited to between one hundred and two hundred feet, save in Kentucky, where the width for one track is one hundred feet, with fifty feet for each extra track. The railroads are required to keep the way clear of weeds, trees and the like, and to construct and keep in repair culverts, bridges, drains and fences.

2. Crossings. An ever-increasing amount of legislation has been enacted of late, covering such points as the maintenance and construction of crossings and approaches ${ }^{1}$ the requirement of gates or flagmen at highway crossings, together with cattleguards and interlocking devices; and, in particular, the separation of grades. The general rule is that highway crossings are not to be at grade, if possible. In South Carolina the consent of the commission is required for the crossing at grade of two railroads.

2 See, for instance of recent legislation, Acts of North Carolina, 1915, ch. cel. 
3. Trains. Regarding no other topic in recent years, probably, have so many laws been passed as about that of trains. (a) With reference to equipment, all the states have shown an increasing solicitude for the health, comfort and safety of passengers. In addition to the statutes covering the adequate heating and lighting of cars, the furnishing of drinking water, and the provision of bell-cords or other signals to the engine there has appeared, of late, an evergrowing number of laws relating to mechanical appliances. The latest example of this tendency seems to be in the prescribing of headlights of a certain power, in which Florida, Mississippi and Virginia have led the way. ${ }^{2}$ The compulsory use of cinder deflectors is a field to which legislators are beginning more and more to turn. ${ }^{2}$ Legislation in regard to the equipment of freight trains has been relatively small, confining itself mainly to the requirement of air, as well as of hand, brakes, and to the attaching of cabooses at the end of trains. Finally, there may be discerned a movement, instituted by South Carolina in I9II, for the empowering of the state railroad commission, by the legislature, to require the installation and use of safety devices. ${ }^{3}$ (b) As to the personnel of trains, legislation has been devoted chiefly to the number of brakemen required on passenger trains, or on freight trains not equipped with train brakes. Attempts have been made to enact "full-crew " legislation, similar to that now in effect in Pennsylvania and elsewhere; but thus far they have met with no success. (c) Statutes regulating the running and service of trains have been very numerous in the past decade. In nearly all the states there

1 Acts of Florida, 1911, ch. mmmmmmccxxxiv; Acts of Mississippi, 1912, ch. cliii; Acts of Virginia, 1914, ch. Ixxxix.

'E. g., Acts of South Carolina, 1909, no. 1xiv; Acts of Georgia, 1912, no. dxvii.

Acts of South Carolina, I9I1, no. ciii. 
are provisions to the effect that trains must be run according to schedule, must not obstruct highways, and must stop before railroad crossings and drawbridges not protected by interlocking devices, and at certain required points (generally county seats). Other provisions regulate such matters as the sounding of a bell or whistle near crossings, the speed of trains in cities, and the running of trains on Sunday. Upon a few of the commissions (notably those of Florida, Georgia, and South Carolina) has been conferred extensive authority over train schedules and time tables. The most interesting regulations, however, have to do with the requirement of equal but separate accommodations for whites and negroes. Beginning with Florida, Louisiana, and Mississippi, the other states have fallen in line in this order: Alabama, Georgia, Tennessee, Kentucky, South Carolina, North Carolina and Virginia. Only in West Virginia is such a requirement lacking. Exceptions, of course, must be made in some instances, as in the case of small branch lines. (d) Finally, about one-third of the states, headed by North Carolina, (1907), have forbidden the serving or drinking of liquor on trains.

4. Stations. Regulations are numerous in regard to the provision of adequate station facilities; the lighting, heating and keeping open of stations, and the correct posting of train bulletins. Requirements as to equal but separate waiting rooms for the races, which first appeared in Alabama, Louisiana and South Carolina, are now on the statute books of over half a dozen states. In Louisiana the commission has recently been given authority over the naming of stations, both as regards those now in existence and those to be built in the future.

5. Tickets. A few states have set a limit to the validity of tickets, and have provided for the redemption of unused tickets. All of them, at one time or another, have made it 
compulsory upon the railroads to sell mileage books, usually at rates lower than one-way fares. The latest statute in this regard is that of Kentucky (I9I4), providing for the issuing of mileage books of rooo miles, or multiples thereof, at two cents a mile by all carriers with annual gross earnings of $\$ 4,000$ per mile or more, and interchangeable with all railroads earning the above amount or more. ${ }^{1}$ Only Alabama and Florida have enacted any legislation against the practise of " ticket scalping".

6. Baggage. The maximum weight of baggage that must be transported free by the carriers has been fixed by a majority of the states at I 50 pounds. In some states, as in North Carolina, the maximum weight is greater when the baggage is checked on a ticket calling for purely intrastate travel than when the baggage is to make an interstate journey.

7. Employees. Legislation with reference to the limiting of the hours of labor, the liability of common carriers in accidents, the methods and time of payment of wages, and similar topics, has been both scanty and unsatisfactory, as measured by northern standards. Georgia and Florida led the way, in the early nineties, with a limitation of the hours of labor, in which movement most of the states have since joined to a greater or less extent. In the matter of the liability of common carriers but little, unfortunately, has been done, and the railroads are still enabled successfully to set up the old plea of contributory negligence as a bar to recovery by employees. Semi-monthly payment of wages has been introduced in Virginia (1912), South Carolina (19I4) and North Carolina (I9I5). The most advanced legislation has appeared in North Carolina. In 1907 that state provided that train dispatchers and telegraph oper-

'Acts of Kentucky, 1914, ch. Ixviii. 
ators were not to work over eight hours out of every twentyfour (though the time might be extended by the corporation commission to twelve hours in cases where the safety of the traveling public would not be endangered), and that members of train crews were not to work more than sixteen hours in every twenty-four. In $191 \mathrm{I}$ it was recognized that train dispatchers and telegraph and other operators had been dealt with too leniently, comparatively speaking, and the law was modified so as to read, in their case, "no longer than nine hours for day and night work, and thirteen hours for day work." Power was again conferred upon the corporation commission to extend this time for good cause shown. ${ }^{2}$ In 1913 it was provided, as regards the liability of a common carrier to its employees, that contributory negligence should be no bar to recovery, since assumption of risk was not to be predicated of the employee's position." Lastly, in 1915 , provision was made for the semi-monthly payment of employees."

8. Interference with Operation. But few statutes have been enacted with respect to this topic. Such laws as do exist forbid, in general, any interference with railroad employees in aid of strike; prohibit the abandoning of a train by its crew in aid of a strike, except at destination; and penalize the refusal of employees, in aid of a strike on another railroad, to operate cars received from that railroad.

9. Other Business. In Kentucky, Virginia and West Virginia the railroads are forbidden to engage in any other business.

10. Pooling. But little attention has been devoted by southern legislatures to this significant topic. In fact, not a single state in the South has ever directly prohibited pool-
1 Acts, 1907, ch. cdivi.
2Ibid, I9t1, ch. cxii.
s Ibid., I9r3. ch. vi.
- Ibid., 1915, ch. xcii. 
ing. The legislators of Florida and Georgia, however, have empowered their respective commissions to prevent all unlawful combinations for the increasing of rates, and those of North and South Carolina have charged their commissions with the duty of approving or disapproving all contracts among railways.

\section{The Regulation of Traffic}

1. The Interchange of Traffic. Provisions are common to the effect that railroads must interchange traffic (in Florida the provision embraces steamboats as well), and must haul the cars of connecting railroads. Several states, beginning with South Carolina, have declared that shipments must be over the route selected by the shipper.

2. The Furnishing of Cars and Facilities. Every state, at some time or other, has either provided that the railroads must furnish adequate car facilities or has delegated to the state railroad commission the duty of looking after this important matter. The tendency has been to clothe the commissions with ever greater power in this respect.

3. The Classification of Freight. The majority of the southern legislatures have wisely refrained from an attempt to do the work that even experts have been unable satisfactorily to accomplish. The most noteworthy example of classification occurred in 1907, when the Alabama legislature, in special session, prepared a classification of, and fixed the maximum rates to be charged for, the transportation of one hundred and ten articles of common use. ${ }^{1}$

4. The Transportation of Dangerous Articles. Very little in the way of legislation is to be found, and that little has to do mainly with the regulation of explosives. ${ }^{2}$

1 Acts, 1907, nos. lxiv-lxxi.

'E. g., Acts of Alabama, I9I I, no. ccclxviii. 
5. Monopolies. Contracts in restraint of trade, and monopolies have been forbidden in the laws of a few states, notably Georgia, Louisiana and South Carolina, and in a couple of the state constitutions.

\section{Rates}

1. Limitation of Freight and Passenger Rates. Every state, without exception, has undertaken at some time or other to regulate passenger fares. Until 1907 the regulation -South Carolina alone excepted-had not been such as to bear with undue severity upon the railroads. But in that year and following years, the states were drawn, as if by suction, into the remarkable " crusade" for passenger-fare reduction that swept over the United States. Virginia led by requiring the issue of mileage books at the unprecedented low rate of two cents a mile. West Virginia followed with the passage of a two-cent fare bill, applicable to all roads of over fifty miles in length; North Carolina came next with the enactment of a two and one-fourth cent fare law, and Alabama, Georgia and Kentucky (1914) fell into line with two and one-half cent fare statutes. Reductions in passenger fares and in mileage book rates were made, also, in the remaining states as the result of conferences with the commissioners of the states concerned.

The present situation is far from satisfactory. The standard intrastate rates (i. e. the rates applying to the major part of passenger traffic) range from two cents a mile in West Virginia to two and one-half cents in Alabama, Georgia, Kentucky, North Carolina, South Carolina, Tennessee and Virginia; two and three-fourths cents in Florida; and three cents in Louisiana and Mississippi. The interstate rate, on the other hand, is two and one-half cents a mile throughout this whole territory. Interchangeable mileage books, good for one thousand miles, are sold in 
each state, except South Carolina, at the rate of two cents a mile.

In the matter of the limitation of freight rates the states have not gone to such extremes. Nearly every state has taken a hand at regulation, but most of them, by this time, have wisely relinquished all control to their respective commissions. North Carolina and Alabama have been the only states within the past decade to order reductions in freight rates by statute. The Alabama statute is still in force, and not only limits the rates that may be charged in the case of one hundred and ten important articles, but also classifies that freight for rate-making purposes.

Where rates and fares are not fixed by statutes, the state commissions are endowed with the authority to prescribe "reasonable and just" charges.

2. Extortion, Rebates and Discrimination. Either by constitutional provisions or by statute every southern state has laid down express prohibitions in regard to this exceedingly important aspect of railway regulation. Variation from established rates is everywhere forbidden.

3. Long and Short Hauls. This subject is principally an interstate matter, and yet all but two of the states (Alabama and Georgia) have seen fit to pass long and short haul provisions, ${ }^{1}$ adopting, in the main, the language of the interstate commerce law. The essential element of elasticity has been recognized by the majority of the states having this provision, in that power has been conferred upon the commissions to "permit the suspension of the long and short haul provision in certain cases and under certain conditions," 2 i. e., in cases where injustice would otherwise result.

1 Most recently in Florida, I9I4.

Meyer, op. cit., p. 146. 
4. Transportation at Reduced Rates. Excursion and commutation tickets, and tickets at reduced rates for children, for political, literary and other gatherings, and for fairs, exhibitions, etc. are the most obvious examples. In addition, tickets at less than regular prices are often granted to institutions of various sorts, such as reformatories, charitable organizations, and the like.

5. Free Transportation. Most of the states have now rather narrowly restricted the granting of free passes to employees of the railroads and their immediate families. This is but in accord with the general anti-pass movement of recent years in the United States. About half of the states have gone so far as to forbid absolutely the free transportation of the railroad commissioners and their staffs. In the other states provision is still made for the free transportation of the commissioners and employees within the state while in the performance of their duties. Free passes are also granted in every commonwealth in special cases deemed particularly meritorious, as, for instance, to traveling secretaries of the Young Men's and Young Women's Christian Associations, and to ex-confederate soldiers attending annual reunions.

In every state except Kentucky and Tennessee it is now a misdemeanor for public officers to accept passes or tickets at rates other than those charged to the ordinary traveling public. It is a matter of deep regret that the legislators of those two states have not seen fit as yet to subordinate their own interests to the larger welfare of their respective states, and to remove that stigma of opprobrium that now attaches to their deliberations by reason of their failure to join the ranks of more public-spirited legislatures.

6. Miscellaneous. Each state has legislated in regard to such matters as the requirement of a certain number of days notice of advance in rates (and in some states, like South 
Carolina and Virginia, regarding notice of a reduction in rates), the minimum for single freight and passenger charges, the exaction of an extra charge for the payment of fares on trains, the filing and publishing of rates, the posting of rates at stations, and the filing of schedules and classifications with the state commissions. In Florida, North and South Carolina, and Tennessee the railroads may be compelled to grant especially low rates for the encouragement of infant industries. Finally, in a number of the states, all roads under one management are considered one railroad for rate-making purposes.

\section{Reports}

I. General Provisions. In each state the railroads are required to make annual reports to the railroad, or corporation, or public service commission, as the case may be, covering operations for the year ending June 3oth. ${ }^{1}$ The reports, some of the details of which are specified by law, must be made in every state in accordance with forms prescribed by the commission. In a few of the states there are also provisions for monthly reports to the commissions.

2. Special Reports. The railroads must report accidents to the commissions immediately after their occurrence, generally by telegraph They must file with the boards copies of contracts with other railroads, car companies, etc. In Kentucky, Mississippi and Tennessee they must make annual reports to the commissions covering the issuance of all free passes. In Virginia they must report annually to the auditor a list of the railroad stockholders residing in Virginia, the number of shares belonging to each, and the par value of the shares.

'In a few states, for the year ending September 30 th. 


\section{CHAPTER V \\ Outline of Commission Development}

\section{Early Agencies of Supervision}

Long before the appearance of the advisory type of commission in the United States there existed in the South, as in other parts of the country, various bodies charged with some special or formal work relating to common carriers. These bodies, known generally as Boards of Public Works or of Internal Improvements, were entrusted with such duties as the administering of state funds for internal improvements, the hearing and deciding upon of applications for state aid, the collecting of reports at periodic intervals from the railroads, and similar matters. As a rule however the members of the boards were already important officers of the state, and, as such, were so much taken up with their own official business that they were unable to devote the proper amount of time to their extra duties. And, further, they were so feebly supported by the state legislatures in the majority of cases that the wonder is that they were able to accomplish anything at all of value, so far as the inspection or supervision of the railroads under their charge was concerned. A reference to the course of development in Virginia will make these points clear.

In 1816 a Board of Public Works was created by the legislature to administer the "Fund for Internal Improvements" established shortly before. The membership comprised the governor, treasurer, attorney-general, and ten 
citizens elected by the general assembly. ${ }^{1}$ The constitution of 1830 selected the governor, lieutenant-governor, treasurer, second auditor, and surveyor of public works as the members of the board. ${ }^{2}$ Three years later the board was reorganized by the legislature, and was reduced to the governor, treasurer, and first and second auditors. ${ }^{3}$ The constitution of $185 \mathrm{I}$ again changed the personnel of the board. The state was divided into three districts, and three commissioners elected by the people-one from each districtattended to the duties of this office until after the Civil War. ${ }^{4}$ The board underwent its final reorganization in 1869 , and from that time until its abolition in 1902 its membership included only the governor, treasurer, and auditor."

The duties of this board, of course, were added to from time to time by the legislature. The most important legislation referred to the making of annual reports by the railroads. A statute of $1837^{\circ}$ required those companies whose lines were entirely within the state, or in whose stocks or bonds the state was financially interested, to make an annual report to the board, covering the amount of their capital stock and their gross and net receipts. This statute erred, first, in not calling for sufficient information, and, second, in not requiring all companies whatsoever doing business in Virginia, regardless of the nature of their mileage, to furnish annual returns. The first defect was remedied somewhat later, at the instance of the board, ${ }^{7}$ but nothing was done about the second until the passage of the commissioner

'Acts, 1815 , ch. xvii.

'See Acts, 1833 , ch. cxii.

2 Acts, 1833 , ch. cxii.

- Constitution, 1851 , art. v, secs. xiv-xvi.

- Ibid., 1869, art. iv, sec. xvii.

- Acts, 1836-37, sec. xxvii.

' Jbid., 1855-56, p. 318 . 
law in 1877. The penalty for failure to make annual returns involved such a slow and clumsy method of procedure -an action of debt-that many companies fell into the custom of making no reports for years at a time. There were some corporations, even, in 1876 , that had never made a report to the board from the date of their organization. ${ }^{1}$

What has been stated of Virginia was true, in the main, of the entire South. From a variety of causes those early boards or commissions, so far as the supervision of railroads was concerned, were so inefficient that their very existence was scarcely felt by the corporations under their jurisdiction.

\section{The Establishment of the Commissions}

The first railroad commission established in the South was that of Virginia in 1877, - a weak commission, very similar in its powers and duties to that of Massachusetts. South Carolina (1878), Kentucky (1880), and Alabama (1881) soon followed with other advisory commissions. Their chief functions consisted in holding the railway corporations to the terms of their charters; in investigating complaints, the most frequent cause of which seems to have been overcharges; in inspecting the actual working of the railroads, with reference, especially, to the adequacy of service; in searching out defects of all kinds; and in the reporting of abuses, accompanied by suggestions of appropriate legislation. Undeniably they served a very useful purpose. But so far as affording the people of those states any real protection from railroad oppression was concerned, they were entirely inadequate. Sooner or later the advisory commissions were cast aside in favor of more vigorous methods of regulation.

' See Reports of Boord of Public Works, for $1860-61$ and 1876. 
The mandatory type of commission arose in the northwestern part of the United States during the seventies in consequence of an agitation for state control by the farmers. The granger societies soon rallied to the support of the movement and became its most loyal adherents. ${ }^{1}$ In 1879 the movement took root in the South with the establishment of the Georgia railroad commission, and from then on its home was chiefly in that portion of the Union. Every other state sooner or later followed suit: South Carolina in I882, Tennessee in 1883 (abolished in 1885 ), Alabama in 1883 , Mississippi in I884, Florida in 1887 (abolished in I89I), North Carolina in 1891 , Tennessee and Florida, again, in 1897, Louisiana in 1899, Kentucky in 1900, Virginia in 1902 and West Virginia in 1913. It is worthy of note that no southern state which has once adopted the strong type of commission has ever rejected it permanently for the advisory sort.

When the Georgia railroad commission came into existence in 1879 there was no other public body in the world, save the California commission, endowed with such arbitrary powers over rates. Nearly all the European states, to be sure, were exercising more or less authority over rates; but none of them outside of Prussia, possessed the despotic power of dictating rate schedules. ${ }^{2}$ In England, for example, the Railway Commissioners were empowered merely to "arbitrate between railroads in a variety of cases"; to secure publicity of rates; and to prescribe certain through rates. " "The primary purpose of establishing this commission was to provide a board to whom any one who had a complaint against the railroads might, without expense to

'Johnson, American Railway Transportation, 1906 ed., p. 357.

- Railroad Gazelle, Aug. 24, 1883.

- Hadley, Railroad Transportation, p. 172. 
himself, appeal for aid in enforcing the act of 1854." I In France the maximum limits of charges were already tixed by law; but the government was wholly without power to prescribe and impose upon the carriers a schedule of rates prepared by itself.

There was one admirable feature of the Georgia commission law that, unfortunately, has been but little copied by the legislators of other southern states. It was provided, namely, not only that the commissioners should be appointed by the governor but also, following the English law, that one of them should be an experienced railroad man. It was hazardous enough to entrust the regulation of the railroads, not to a highly-trained body of experts, but simply to three citizens, only one of whom had any special knowledge of the railroad business. But it was positively absurd to expect, as most of the southern legislatures did, that three men " entirely inexperienced in railroad business," and "entirely ignorant of the principles underlying and controlling the fixing of rates and the establishment of tariff charges" could handle the railroad situation with justice, not alone to the people, but to the carriers as well. As the Tennessee commission well stated in its report for $1897-98$,

When it is understood that the many thousands of articles transported by the railroads are divided and subdivided into classes and subclasses, and that before a reasonable, fair and intelligent classification and subclassification can be made it is absolutely necessary to have a thorough knowledge of the bulkage, liability to damage, value of the article, cost of handling, the shape in which it is transported, its inflammatory character, together with many other items of information, and that before you can establish rates upon classes the freight charges upon each article hauled nuust be taken in connection with the freight charged upon all the other articles trans-

2 Johnson, op. cit., p. 328. 
ported; that the total amount of income so derived from shippers upon every branch of the entire system for the year in connection with all other incomes of the road, including rentals and interest upon stocks and bonds, is to be estimated in connection with disbursements of every kind in order to test the business affairs of the road and determine whether that particular rate so fixed will yield to the company a reasonable profit upon the capital invested in the enterprise, it will be seen that it presents a problem of difficult solution. ${ }^{1}$

In fact, a more arduous task than the preparation of classifications of freight and of freight and passenger rate schedules could not easily be imagined. The men best fitted by experience to prepare those classifications and schedules were, of course, the traffic managers and experts of the railroads. But it was to eradicate the evils of the very schedules prepared by those men and in force throughout the South that the commissions had been created. The commissioners had to rely in the main, then, upon their own observations and the testimony of shippers. And it was not to be expected that their work should prove acceptable to the carriers. The consequence was a violent contest in the courts,- at times immediately upon the creation of the commissions, to determine the validity, not only of the rates and regulations promulgated by the commissioners, but also of the very existence of the commissions. All of the arguments brought to light in the granger cases of the seventies were raked up and exploited to their fullest extent in an endeavor to thwart the will of the people. Since the objections raised by the railroads brought up for discussion several points of very considerable interest and importance, it may be worth while to examine them somewhat in detail as illustrated in the conflict between the railroads and the Virginia commission in 1906 and 1907.

' Report of the Tennessee Railroad Commission, 1897-98, pp. 31-32. 
In March of 1906 the Virginia legislature directed the commission to prescribe a schedule of passenger rates for all transportation companies doing business within the state. The commission, in all probability, was not bound by the resolution, for the Virginia constitution expressly prohibits the assembly from legislating in the matter of rates. In obedience, however, to what it deemed a popular demand, the commission served a notice upon all the steam railroads operating in the state, fixing upon November I, 1906, as the date upon which they might file their objections to the prescribing of a maximum intrastate passenger rate of two cents a mile. ${ }^{1}$

1. The railroads, first of all, challenged the right of the commission to take any sort of action in the proceeding. They maintained that the Virginia constitution, when it provided for the creation of a tribunal with judicial, legislative, and executive powers, violated the Fourteenth Amendment of the United States Constitution; for in being compelled to submit their controversies to the commission and to the commission alone, - a tribunal which is unlike the regular courts of the state-they were, they alleged. being denied the equal protection of the laws. The commissioners made short work of this argument. They simply showed that the question had been shortly before passed upon by the Supreme Court of the state, and that the provisions of the constitution in dispute had been there upheld as valid. ${ }^{2}$

2. The railroads argued, in the second place, that a contract existed between the state and those railroads which had been granted their charters before the adoption of the constitution in 1902, according to which the state had abandoned the right of prescribing tolls or charges upon these

1 Report of Corporation Commission, 1906, p. ix.

- Winchester and Strasburg Railroal Cn. z's. The Commonwealth of Virginia, 106 Va., 264. 
railroads. The obligation of that contract had therefore been impaired, it was alleged, by the power conferred upon the commission of prescribing rates, and hence its action in fixing a maximum passenger rate was void. ${ }^{1}$

In support of this second contention the carriers pointed to certain sections of the Virginia Code of 1887 . Section $124^{\circ}$ provided that as regards the charter of any company governed by the act of March, I837-a general law regulating the incorporation of railroads-" no law shall be passed for taking from a company its works or property without making to it just compensation, or for changing its tolls without its consent, in any other cases than such as are provided for in this chapter." Section 1242 declared that no law should so reduce the tolls of a railroad as to render impossible the payment, annually, of dividends of fifteen per cent within thirty years from the time of the first declaration of dividends, or of dividends of twelve per cent after the said thirty years and before fifty years from the same time, or of dividends of ten per cent after the said fifty years. The railroads then pleaded that their net profits had never at any time been so large as to permit them to declare the respective dividends as named above, and that the state, accordingly, was bound to them by a contract not to pass any law altering the rate of tolls or charges until such time as the dividends mentioned in the statute had been earned, - except, of course, with the consent of the companies. $^{2}$

The commission answered these contentions with decisions of the United States Supreme Court, ${ }^{8}$ and with a case re-

1 Report of Corporation Commission, 1907, p. 75.

2 Ibid., 1907, p. 76.

'Louisville and Nashville Railroad Co. vs. Kentucky, 183 U. S., 503; San Antonio Traction Co. z's. Altgeld, 200 U. S., 304; Chicago, etc., Railroad Co. 2's. Minnesota, 134 U. S., 455. 
cently decided by the Circuit Court of the United States for the Western District of Texas. ${ }^{2}$ It showed that the Supreme Court, on the principle that no legislature can bind future legislatures or constitutional conventions to relinquish their right to the exercise of the police power,-that vague authority which may be broadly defined as the right of the state "to do anything designed to promote general welfare as opposed to special privilege" " - has steadfastly refused to concede the validity of such a contract between a state and a railroad company. The commission therefore held that there was

nothing in the charter of any of the companies which either expressly or by implication exempted them from liability to future legislation as to the prescribing of rates, and hence no contract between the state and the railroads arose; that all the companies, whether chartered by special act of the legislature or under the general law, took their charters subject to the general laws, and to such changes as might be made in the general law, and subject to future constitutional provisions and future general legislation. ${ }^{3}$

3. Having thus disposed of these two preliminary questions, the commission entered upon a consideration of two other objections advanced by the defendant railroad companies. The railroads alleged, in the third place, that the proposed maximum passenger rate was in violation of the commerce clause of the United States Constitution, inasmuch as interstate passenger rates are often the result, in part or in whole, of intrastate rates. The commission, however, in view of the many adverse decisions of the United

'Houston and T. C. Railroad Co. z's. Storey, 149 Fed. Rep., 499.

- Beard, American Government and Politics, p. 440.

- Report of Corporation Commission, 1907. p. 70. 
States Supreme Court on this point, rejected this contention as clearly of no value.

4. Finally, the railroads brought forward their strongest and most natural argument, declaring that a maximum passenger rate of two cents a mile would be unreasonable and confiscatory. They contended that such a low rate, resulting surely in an abnormal decrease in their earnings, would necessarily deprive them, without just compensation, of a reasonable income, and that since such a taking of income is tantamount to a taking of property, the enforcement of the two-cent rate would deprive them of their property without due process of law. ${ }^{1}$

Regarding the ultimate victories of the various commissions in the courts, sufficient has elsewhere been said. The main point is that once the authority of the commissioners and the validity of their regulations were determined in the affirmative by the United States Supreme Court, the majority of the roads bowed to the inevitable. Only now and then in recent years, comparatively speaking, have the carriers sought to hamper the commissions in their work with the vexatious delays of litigation. The contesting of orders appears to have been most frequent in North Carolina, Florida, Kentucky and Louisiana. However, with the exception, possibly, of the last-mentioned state, this practise may now be said to be decidedly on the wane.

The most important achievements of the commissioners have been the prescribing of schedules of either absolute or maximum rates, and the establishment of fixed classifications of freight. The most serious objection to the system in vogue before the advent of railway regulation was the continual fluctuation in classification that occurred, the railroads having power to increase rates at pleasure by

1 Report of Corporation Commission, 1907, p. 79. 
simply making changes in classification. These changes were not only made without warning, but they succeeded one another with a rapidity that deprived shippers and consumers of any basis upon which to conduct operations - of any fixed data by which to adjust their business affairs. - Business was unsettled, confidence undermined and the movement of traffic disturbed, to the ultimate injury of all concerned. ${ }^{2}$

These evils have certainly been reduced to a minimum by the adoption in each state of a stable freight classification promulgated by the state commission.

\section{The "Crusade" against the Railroads}

In the comparative calm of the past few years between railroads and commissions, however, there has been one significant interruption, - an interruption occasioned by an extraordinary popular movement for rate reduction and restrictive railway legislation that swept over the entire country in 1906 and succeeding years. Laws were enacted

creating railroad commissions, reducing freight and passenger rates, prohibiting discriminations and rebates, establishing penalties for delay in the transportation of goods, enforcing liability for damages to passengers, prohibiting free passes, reducing the hours of labor of railroad employees, requiring the introduction of safety appliances, prohibiting combinations and traffic agreements, and dealing with a host of other questions arising in the course of the transportation business. ${ }^{2}$

For this mass of hostile legislation the railroads themselves, to a great extent, were to blame. The deepest-seated cause of discontent on the part of the people was the widespread prevalence of that ancient evil, discrimination, which,

1 Report of Florida Railroad Commission, 1901-2, p. 18.

"Wm. H. Glasson, "The Crusade Against the Railroads," South Allontic Quarterly, April, 1907. 
despite numerous laws on the statute books, frequent convictions in the courts, and the earnest efforts of the more intelligent railroad managers, was still flourishing,- -and in no part of the country more vigorously than in the South. A second ground of dissatisfaction,-nearly equal in importance to the first, was the revelation by the Interstate Commerce Commission and other public agencies from time to time of the way in which railroad property had been made the subject of speculative manipulation by "insiders" in various "re-adjustments." Stock jobbing and watering had been indulged in by nearly all the southern carriers, the classic example of which was furnished in the reorganization of the Southern Railway in 1894 by the banking house of J. P. Morgan \& Co., when, as a part of the reorganization scheme, $\$ 120,000,000$ of common stock was issued to persons who paid not a single dollar in actual value for it. As a consequence, a great many of the roads doing business in the South were burdened with a volume of securities, more or less watered, which sorely handicapped them in their endeavors at betterments, and which made it a constant struggle to meet interest charges and pay dividends. A third ground of discontent was to be found in the inefficiency of the railroads' service. For several years prior to 1907 the management of both freight and passenger traffic in the South had seemed, at times, "utterly demoralized". "Worse than this, in recent months, on what are supposed to be the best railroads of the country" there had occurred "an appalling series of passenger train wrecks with hundreds of persons maimed and killed." " The Southern Railway, for instance, had killed its own President. Finally, many of the roads had apparently neglected to instruct their employees in the elemental rules of courtesy to

$$
\text { 'Wm. H. Glasson, op. cit., April, } 1907 .
$$


passengers, with the result that complaints as to the want of consideration for travellers were both numerous and wellfounded.

The agitation against the railroads, however, was carried far beyond its proper bounds by the efforts of petty politicians, who, with an eye single to their own advancement, took advantage of the popular disaffection to sweep themselves into power as the champions of the people. They promptly proceeded to deal with the carriers in a most arbitrary manner, giving attention, not so much to the question of justice as between the roads and the people, as to the feathering of their own political nests.

The result of the mass of legislation that issued from the southern assemblies in 1907 and succeeding years, so far as the commissions were concerned, was to add very greatly to their powers and duties. Most of the roads, as, for instance, the Southern Railway, the Seaboard Air Line, and the Atlantic Coast Line, deemed it the "policy of wisdom to adopt conciliatory methods, to comply with the law in good faith, to give as good service as possible, and to avoid any unnecessary show of defiance or retaliation." s Others, however, notably the Louisville and Nashville, appealed to the courts for relief from harsh and oppressive laws on the ground that the legislature had overthrown constitutional restrictions and had virtually confiscated private property. These roads resorted to every possible legal device to hinder the execution of the obnoxious laws. In some states, as in North Carolina and Georgia, the contest was sharp and short; in others, as in Alabama and Kentucky, the railroads succeeded in holding up the orders of the commissions for half a decade or more.

Outward quiet again prevails in the southern states.

'Wm. H. Glasson, of. cit., April. 1907. 
54 REGULATION OF RAILROADS IN THE SOUTH [364

Now and then mutterings are heard, as recently in North Carolina. But on the whole the railroads appear to have resigned themselves to a policy of conciliation and to an abandonment of methods of defiance. They seem to have determined, for the present, at least, and with but few exceptions, to give to the public the best service possible under the rigorous restrictions of present commission laws. 


\section{CHAPTER VI}

VIRGINIA

\section{The Advisory Commission}

THE fight for a railroad commission in Virginia began in the session of the legislature of $1872-73$, when a bill was reported, but not acted upon, which provided for a commissioner to examine into the business of the railroad companies and to report annually to the legislature as to their condition and charges. ${ }^{1}$ At the next session in 1874-75, in response to the appeal of Governor Kemper, ${ }^{2}$ a bill was introduced in the house looking to the appointment of "commissioners of transportation." The committee on roads and internal navigation, to which it was referred, reported out a substitute which passed the house rather easily but was rejected by the senate. ${ }^{3}$

Two years later the st1 uggle was renewed, and this time with success. Bills were reported in both houses, of which the most important proved to be a bill by General Johnson, for years an advocate of the commission idea, providing for a board of three commissioners, with the power to compel the railroads to carry out the obligations of their charters, and to charge such rates only as the board should deem reasonable. To most of the senators, however, such a bill was most unpalatable, and it had to be toned down very

1 House Journal, 1872-73, pp. 378-9.

- Senate Journal, 1874-75, p. 15.

3 Ibid., p. 371; House Jourmal, 1874-75, p. 310. 
considerably before its final passage in the closing days of the session. The house proposed a few amendments to which the senate agreed, and early in April, I877, there came into existence the first commission to be established south of the Ohio and Potomac and east of the Mississippi rivers, and designed to deal with the ever-increasing perplexities of the railroad problem. ${ }^{1}$

As finally approved by the governor, the law made provision for one commissioner, to be elected biennially by the general assembly, and with functions purely supervisory and recommendatory. It was made his duty to examine the physical condition and the manner of operation of all the steam railroads in the state as often as he should deem necessary to keep hinself well-informed, and to see that the terms of their charters and the provisions of the law were fully complied with. Whenever, in his judgment, grounds should arise for changes in the mode of operation or of conducting business necessary to the promotion of the convenience and security of the public, or whenever any violation of the law should be made known to him, he was to call the attention of the company at fault immediately to the required correction. If compliance with his order did not follow within sixty days he should report such failure to the board of public works and, if so directed, apply to the circuit court for an injunction. The annual reports of the railroads were now to be made to the commissioner who, in his turn, was to submit each year to the general assembly a report based upon these returns, and embodying such statements and statistics as would clearly reveal the actual working of the railroads operating in Virginia. ${ }^{2}$

Thomas Henry Carter, elected by the general assembly

'Senate Journal, 1876-77, pp. 42, 299-300; House Journal, 1876-77, pp. 446, 467-68; Richmond Dispatch, April 3, 1877.

2 Acts of Virginia, 1876-77, ch. ccliv. 
as the first commissioner, was a descendant of an old and distinguished Virginia family, and a successful gentleman farmer. He had no intimate acquaintance, of course, with the railroad problems of his state. In his first two reports he announced the policy that he would pursue in regard to the all-important question of discrimination. He took the position that he would be entirely justified in permitting the continuance of just, as compared with unjust, discrimination.

"For it is a mistake to maintain," he said, "because local rates are in proportion much higher than through rates, that therefore local rates are necessarily exorbitant. It should always be borne in mind that the through traffic, on account of the active competition to which we have referred, must often be taken at the lowest figure inside of the slightest profit, or not taken at all." " "So long as there is a profit on through traffic that profit is, as far as it goes, a relief to the burden on local traffic." 2

The greatest danger, in his opinion, was that the commerce and industries of the state might be unduly injured by the diversion to railroads operating in other states of through traffic ordinarily passing through and beyond Virginia, in case rates were unscientifically interfered with by governmental agencies. In common with the commissioners who came after him he appears to have been obsessed with the idea that the prosperity of his own state must be very jealously guarded, and that it was decidedly hazardous to tamper with the through rates, no matter how discriminating, so long as those rates made possible the transportation of freight over Virginia lines in place of those of adjoining and competing states."

1 Report of Virginia Railroad Commissioner, 1878, p. 8.

? lbid., 1877, p. 9. 
As one reads over the reports of the commissioners from the early eighties on, however, one finds with increasing frequency the old, familiar complaint in regard to unreasonable discrimination cropping up. Shippers, for example, angrily inquire of the commissioner why they should be required to pay more to ship their leaf tobacco from Danville to Richmond than their competitors at Louisville, Ky., over six hundred miles further distant. Discriminations, in multitudes of cases, seemed to be made for no good or sufficient reasons. The commissioners reported that many of the shippers, in particular the farmers, were becoming very hostile to the railroads, and were demanding further legislation to protect them against the unreasonable differences in rates for long and short distances. They noted with some alarm that many people were favoring legislation for Virginia modeled upon the Georgia law of 1879 , which had given the railroad commission of that state rather arbitrary powers in the making of rates and the examination of books, accounts, etc. They observed with evident relief that the weight of public opinion in Virginia, so far as they could judge, was still very much opposed to conferring on any one man or any set of men such inquisitorial power. ${ }^{2}$

The office of railroad commissioner had a comparatively lengthy existence, from 1877 to 1902 , when it gave place to a corporation commission. The various commissioners during those twenty-five years performed a very valuable service for the people of Virginia, more especially in harmonizing the relations of shippers and carriers in ways that seldom, if ever, came to public notice. The nature of the office encouraged the bringing of complaints of every conceivable kind regarding such matters as inadequate service, lack of proper station facilities, negligence, damages, over-

\footnotetext{
1 Report of Virginia Railroad Commissioner, 1880-1889, in particular $1887-88$.
} 
charges (the commonest of all causes of complaint), and the like. And to the credit of the commissioners let it be said that their suggestions to the carriers were as a rule readily adopted, and that the majority of the complaints were adjusted to the satisfaction of the complainants.

The fact is, nevertheless, that the commissioners were unable to cope with the railroad problem as it developed on an ever-increasing scale in Virginia. There were two obstacles that stood steadily in their way, and that increased in importance from year to year. There was, first, the limited nature of their jurisdiction, and, second, the constant growth in interstate commerce, over which, of course, they had no control. If they had had the power to prescribe absolute rates they could have prevented, in large measure, that most serious of all railroad abuses,-discrimination. As it was, the railroads had only to keep within the maximum rates prescribed early in Virginia's railroad history by her legislature; and they found no difficulty in doing this, for the maximum, in the bargain, had been set entirely too high. Then, again, the commissioners had no authority over the issue of stocks and bonds by the carriers of the state. and were forced to sit idly by while financiers in New York manipulated securities and promoted consolidations that imposed a perpetual tax on the people served by their railroads.

As far as interstate commerce was concerned the commissioners were no worse off than were the commissioners of most of the other states, where the increase in this sort of commerce has been continual and at times very rapid. Suffice it to say that by the end of the century most of the freight carried in Virginia was either destined for other states or foreign countries, or was originating outside her boundaries. When complaints regarding discriminations in the transportation of such freight came to them there was very little that they could do to remedy matters. 
Needless to say, there were frequent attempts during all this time to strengthen the authority of the commission, in addition to the enactment of legislation against discrimination, rebates and so on. The very year after the commissioner law went into effect the senate passed a bill increasing his powers, but it died in the house committee. ${ }^{1}$

The session of $1883-84$ was the occasion of a spirited endeavor to establish a powerful board of railroad commissioners on the lines of the Georgia law of 1879 . The idea seems to have blossomed forth first with Governor Cameron. In his message to the legislature he urgently commended to its consideration "the laws by which other states of the Union, notably the states of California and Georgia, regulate the railway administration within their borders,-laws which have stood the examination of the courts and survived the test of experiment to the satisfaction of the people without injury to the railroads." ${ }^{2}$ The house promptly reported and quickly passed a bill substituting for the onecommissioner system a board of railroad commissioners with extensive powers. In the senate a substitute bill was reported from committee which was rejected on its third reading by but the narrowest of margins. ${ }^{3}$

At the extra session in 1884 the lower chamber again passed a bill providing for a board of commissioners, and again it was rejected by the senate. ${ }^{4}$

Seven years later the struggle was renewed when Governor McKinney, in his annual message, took up the cudgels in favor of stricter regulation. After remarking upon the

'Senate Journal, 1877-78, pp. 280-81 ; House Journal, 1877-78, p. 313.

' House Journal, 1883-84, p. 23.

- Scnate Journal, 1883-84, pp. 644-45; House Journal, 1883-84, p. 579.

- Senate Journal, 1884, p. 241; House Journal, 1883-84, p. 200 . See also House Journal for $1885-86$, pp. 374-75. 
good that the railroads had done and were still doing he observed:

To see that the railroad laws of the state are faithfully executed and that the citizen is protected in all his rights against the company which may wrong him, three railroad commissioners should be selected, with powers sufficient for the purposes indicated. The people would be better satisfied with three than one. They would strengthen one another and restrain one another. Their decisions would carry more weight and give greater satisfaction. ${ }^{2}$

Responsive to this suggestion Mr. Kent, long a spokesman in the legislature for commission regulation, introduced a measure patterned very closely after the Georgia model of 1879. It encountered but little opposition in the house, and after its passage there, was sent over to the senate for consideration. $^{2}$

This bill met with the endorsement of many business men throughout the state. It found approval, for example, with the Richmond Chamber of Commerce. Moreover, at a meeting of this body held to consider the bill, representatives of the railroads were present, who stated that although they were not in favor of any kind of commission regulation, the measure under consideration was fair and moderate, and that if they had to submit to some kind of bill they would prefer to face that one. ${ }^{3}$

Editorial opinion, on the contrary, was very much opposed to conferring on the commission such authority, and in particular, the authority to fix rates. It demanded proof that the Virginia situation was of such a desperate character as to stand in need of such an extreme law, and declared

1 House Journal, 1891-92, p. 24.

2 lbid., 1891-92, pp. 510-11.

- Report of Richmond Chamber of Commerce, 1891-93. p. 82. 
that the conservative people of the commonwealth were not asking for a measure of that sort. Such a provision, it affirmed, would fall like a wet blanket on railroad enterprise; it would put an end to the building of new roads or the extension of old ones.

"Our judgment," said the most prominent of the Richmond newspapers, "is against conferring the power on the commission to originate the rates. Let the railroad companies announce their rates and schedules, and then, if they are not all they should be, let the commission notify them what they regard as fair and reasonable, and demand that the change be made. If any company declines to adopt the rates fixed by the commission, the commission should have the power to summon the company into court, there to have the questions at issue determined, and pending this decision the company's rate could continue operative, but with the express stipulation that any sums in excess of the rates finally adjudged reasonable by the court should be refunded to the shipper. Such a provision would afford to the public a sufficient guarantee against unjust and discriminating tariffs and injurious schedules." 1

The fight in the senate was exceedingly warm. But finally the opponents of stringent regulation won the day, and the bill was so amended as to lop off the most drastic provisions, including the board of commissioners feature. ${ }^{2}$ With this defeat the friends of the Georgia commission idea appear to have lost heart. During the following ten years, with the exception of the session of $1897-98$, , not a single bill looking to the creation of a mandatory commission was reported in either house.

1 Richmond Times-Despatch, Dec. 20, 1891.

- Senate Journal, 1891-92, pp. 544-45.

'Ibid., 1897-98, p. 136; House Journal, 1897-98, p. 214 
In the bill which passed the house and which was so radically amended in the senate in 1892 there was one very important provision that both the board of public works and the railroad commissioners had sought for many years to incorporate into the law. It will be remembered that up to that time the railroad commissioner, upon discovering a violation of the law by a carrier, was empowered merely to bring the violation to the notice of the carrier, and in case of refusal by the latter to heed this notice within sixty days, to present the matter to the board of public works for such action as it should deem proper. The board might then order the commissioner to appear before a circuit court of the state, and ask for an injunction to prevent further violation of the law. This method of procedure had not worked well in practice, for the reason that the members of the board were already so overwhelmed with the work of their respective offices that they had but little time for the consideration of communications from the railroad commissioner. Some remedy for this state of affairs had long been needed if the commissioner were to accomplish the ends for which his office had been created.

The fourteenth clause of this bill, as it was finally agreed upon by the legislature and approved by the governor, supplied the necessary relief. It provided that in case of the violation of any part of the law the commissioner should, immediately upon the receipt of a complaint, request the carrier to correct its cause. If within ten days the carrier should fail to comply with this request. the commissioner was to proceed in the name of the commonwealth against the company before a circuit court of the county where the cause of action arose, or a judge thereof in vacation. The case was to have precedence over all other business before the court, and was to be heard without formal pleadings. It should be the duty of the state attorney to represent the 
commissioner. The judge, if convinced that the law had been violated, was to prevent further violation by the issuance of an injunction. Both the commonwealth and the carrier were granted the right of appeal to the supreme court of appeals,- - the highest court in the state. ${ }^{1}$

The instituting of this prompt and inexpensive manner of redress was certainly a long step in the right direction. And yet it failed to reach the pith of the situation, for discrimination continued to flourish as in years past, in spite of enactments designed to crush its existence and in spite of the frequent endeavors of the railroad managers themselves. Thus matters dragged along for years. Men who had the railroad problems of Virginia at heart and who felt dispirited at the apparent apathy of the legislature were at a loss to know what to do. They simply waited, therefore, in the hope that finally something favorable would turn up which they could utilize to their advantage; and a long wait it proved to be.

\section{The Creation of the Corporation Commission}

Not until I90 I did the opportunity arise,-an unexampled opportunity, as it proved to be. Incited by the example of Mississippi ( 1890 ), South Carolina (I895), Louisiana ( 1898 ) and North Carolina (I900), the Virginia legislature called a state convention empowered to frame a new constitution disfranchising negroes, and to put it into force without submission to ratification by the people. Among the delegates were many gentlemen with a lively interest in the railroad problem, who realized that the long hoped-for occasion had now come. Headed by the Hon. A. Caperton Braxton, at that time the foremost champion in the state of stricter regulation, they persuaded

'Richmond Times-Despatch, March 4, I892. Acts, I892, ch. dcxiv. 
the convention to appoint a committee to consider and re port upon advisable measures concerning the railway situation.

The committee reflected that although the Virginia advisory commissioner had performed a very useful service in the collection of statistics, the searching out and reporting of defects, and the like, he had been utterly powerless to protect the people from the oppression of the railroads. It considered next the administrative type of commission, such as Georgia in 1879 and North Carolina in 1899 had resorted to, whose members, in addition to enjoying the powers of the advisory commission, are clothed with the authority to prescribe passenger fares and freight rates and to require the maintenance of adequate service and facilities. It thoroughly approved the good results achieved by these boards, in themselves really little legislatures, and able, by reason of their simply designed machinery, to equal the mobility and quickness of action of even the astutest railroad managers. One defect, however, -and, that, in its opinion, a very serious one-was to be found in the working of these administrative commissions, - the lack, namely, of judicial powers. For example, this type of commission cannot enforce, of itself, its own rates or regulations. If these are not voluntarily obeyed by the carriers the commission must appear before an ordinary court and prosecute the unwilling company for their alleged violation. Courts of procedure are notoriously slow, so that it may happen that the rate or regulation, when finally passed upon by the court, may be found to be inapplicable if conditions have changed in the meantime. Then again, even supposing that the court reviews the constitutionality of the rate with extraordinary swiftness, the railroad can cause infinite delay in those states where the practice has not yet been regulated, by bringing 
before the court material evidence which it has previously concealed from the commission, and which is enough to compel the court to dismiss the whole proceeding and to force the commission to begin its work all over again. Or the violations may be so frequent that the commission is unable to prosecute them all, in which case, unless private persons prosecute them on their own account and at considerable expense to themselves, many transgressions of the law go unpunished.

Such were the considerations before the convention. To the committee there seemed but one way out of the difficulty,-a bold experiment, by the way, in American practice; and it determined finally upon the adoption of that method. It proposed to solve the difficulty by the creation of an absolutely unique body,-a commission, namely, endowed not alone with administrative and legislative powers, but also with judicial powers. It determined to have all questions relating to the validity of a charge prescribed by the future commission conclusively settled at the time when the charge was prescribed, thus doing away with the delay and expense attendant upon the prevailing method of proceedings before a court, and compelling the railroads to bring forward their entire evidence during the consideration of the charge by the commission. To prevent the questioning of the commission's regulations after their promulgation, the committee proposed to give the carriers the full benefit of the indispensable principle of jurisprudence known as due process of law, by providing that the railroads to be affected by a regulation of the commission must be duly notified thereof and must have a fair judicial hearing upon every question affecting the validity of the proposed regulation. Arrangement was made for the right of appeal from the commission's decision to the Virginia Supreme Court of Appeals. To prevent any abuse by the commission of its 
legislative power, from the exercise of which, of course, there can be no appeal, the committee resolved to reserve to the legislature the preeminent authority in legislation on all matters affecting railroads. An exception, however, was made in the case of the classification of freight and the prescribing of charges; for the general assembly is too unwieldy and too inexpert in railroad matters to be able to fix charges and classifications in the minute detail demanded by present-day conditions.

Finally the comnittee proposed to have the future commissioners appointed by the governor, and for long terms, well knowing that if the commissioners were to be elected by the legislature the result would be short terms of office and a tendency to subordinate the dignity and the importance of those offices to the political aspirations of ambitious but inferior men. ${ }^{3}$

The report of the committee met with the enthusiastic approval of those members of the convention who were desirous of secing an end put to the abuses of the railroad régime, and after a warm discussion its main features were elaborated and incorporated in the constitution. The constitution, as framed, was put into force without submitting it to popular ratification. Thus came into being, by a lucky chance, an extraordinary form of commission that was destined to be of immense value to the people of Virginia, and to whose creation under ordinary circumstances the legislature, with its profound reverence for the traditional policy of the division of powers, would have proved an insuperable obstacle. The commission went into office on March I, 1903 .

The Virginia state corporation commission is a board of three persons whose members are appointed by the governor

- American Law Recriew, vol. xxxviii, pp. 489-497. Journal and Documents of the Constitutional Convention, pp. 4t8-37. 
for a term of six years, one member retiring every two years. The annual salary is $\$ 4000$ with $\$ 500$ additional for the chairman. No commissioner may be financially interested in any transportation or transmission company under the jurisdiction of the commission.

The most interesting and instructive feature of this commission is the wide extent of its functions. It is at once an administrative body, a legislative body, and a court of record.

As an administrative body it issues all charters and amendments thereof for domestic corporations, and supervises the foreign corporations that are permitted to do business in Virginia. Its jurisdiction extends to all save municipal corporations and institutions owned by the state. To the general assembly, however, is reserved the right to repeal any charter at any time, although it has no immediate authority to regulate the affairs of the corporation. The commission is required both to assess the real and personal property of all public service corporations, for the purpose of state, county and district taxation, and to levy the fees and franchise and license taxes laid upon those corporations. It is its duty, also, to inquire into the abuse of charter privileges by transportation and transmission companies, and into the physical condition and service of any road, in order that necessary improvements may be made as needed. Full permission is given to examine the books and papers of corporations, and to prescribe uniform methods of bookkeeping.

As a legislative body it prescribes classifications and rates for transportation companies, rates for transmission companies, and such other regulations as are permissible.

As a court of record the commission passes upon the validity of its proposed regulations, and after their enactment enforces the necessary obedience to them. It is a full-Redged court, equipped with the necessary subordinates, 
with power to compel the attendance of witnesses and the production of papers, and to fine or imprison for contempt of court. The only appeal pernitted from its decision is to the Supreme Court of Appeals, and this court is not allowed to examine into any evidence that was not before the commission when the question was being adjudicated. In case a rate prescribed by this body is declared void by the Court of Appeals, the latter is bound to prescribe an alternative rate, which goes into effect as if fixed by the commission. In the case of an order prescribing charges or classifications, an appeal to the Supreme Court operates to stay such order only when a bond is filed by the corporation to guarantee the repayment of any overcharges. If no such bond is filed, the charge or classification goes into effect pending the result of the appeal. ${ }^{2}$

\section{The Work of the State Corporation Commission}

During the few months of their official term in 1903, the commissioners were unable to do more than to start the work of preparation for the arduous labors of the future. In the summer they made a tour of inspection over most of the railroad mileage in the state, examining fully into the condition of the roadbeds, the rolling stock, and the station buildings. Next, in pursuance of a section of the new constitution and of a revenue law recently enacted, they appraised the property of all railroad companies doing business in Virginia, and assessed against those companies the state franchise tax of one per cent upon their annual gross revenue. $^{2}$

This done, they turned their attention to the exceedingly important problem of the classification of freight, and freight

1 See chs. clv-clvi of the Virginia Constitution, 1902.

- Report of Corporation Commission, 1903, p. 6. 
rates. The situation in Virginia had been very much complicated for a number of years by the prevalence of two kinds of freight classifications, - the "southern" and the "official" classifications. Roads like the Atlantic Coast Line, the Seaboard, and the Southern, which run north and south through the state, had their rates fixed and their freight classified in conformity with the "southern " classification, predominant in that part of the United States lying, roughly, south of the Ohio and east of the Mississippi rivers; while those roads that run east and west, like the Nor folk and Western, and the Chesapeake and Ohio, were governed in their freight rates and classification by the "official " classification,- - the classification prevailing north of the Ohio and Potomac and east of Chicago. Articles of freight in these two classifications were grouped in classes, - articles in the first class bearing the highest rate, those in the second class a lower rate, and so on. Various articles, in addition, had been given special or " commodity" rates. Finally, the railroads were in the habit of issuing from time to time exception sheets, containing changes in both classification and commodity rates. As a consequence, then, there was a great lack of uniformity in rates on the several roads. For instance, the rate on certain articles on a given railroad differed from the rate for the same distance on another railroad. Moreover, it was no easy matter to ascertain, at any one time, just what the exact rate on a specific article between given points was. ${ }^{1}$

With these points firmly in mind, and aware of the involved nature of the situation, the commission resolved to enter upon a detailed investigation of the question, in the belief that the fairness of the freight rates then prevalent in Virginia could not be properly determined without a previous

1 Report of Corporation Commission, 1904, p. 10. 
consideration of the practicability of a single uniform classification for all the railroads of the state. But before it had proceeded far in this investigation, its attention was diverted for a time to another and quite different question.

In May of 1903 the general assembly passed a law, requiring the corporation commission to "fix and prescribe storage, demurrage, and car-service charges, which may be collected by railroad or other transportation companies on freight transported or to be transported by them, and to be paid by them on freight delayed and cars not promptly furnished or placed by them." 1 The commission, as required by the constitution, addressed a notice to all the interested parties, fixing upon June 29, 1903, as the date for the hearing in this matter, and appending the rules which it had in mind to establish. After taking the testimony of many of the transportation companies and shippers, and after much deliberation, it prescribed certain rules and regulations which, on the whole, were more favorable to shippers than to the railroads. ${ }^{2}$ The latter thereupon appealed to the Virginia Supreme Court. The validity of the rules was attacked by them, strangely enough, not upon the ground of their unreasonableness, but upon the grounds that the commerce clause of the United States Constitution and various acts passed in pursuance thereof would be violated in so far as the rules applied to foreign and interstate commerce; and that the Fourteenth Amendment of the United States Constitution forbids the taking and use of private property without due process of law, - a result that would follow, the appellants alleged, from certain of the rules. The court of appeals, however, basing its conclusions upon numerous decisions of the Supreme Court of the United

1 Acts, 1903, ch. cclx. Report of Corporation Commission, 1904. p. Io4.

Ibid., 1904, p. 45. 
States, ${ }^{1}$ refused to entertain these arguments. ${ }^{2}$ A few days later, accordingly, the commission put its regulations into effect, ${ }^{3}$ and they have continued in effect ever since without dispute.

Encouraged by the favorable outcome of this matter, the commission proceeded all the more vigorously, both by informal correspondence and by formal judicial hearings, in its consideration of the freight-rate situation in Virginia. In January, I905, it held a hearing at which the railroads appeared, and at which the feasibility of a uniform freight classification was minutely inquired into. Convinced by this hearing that such a classification was practicable, the commission then formulated a single classification for all the railroads in the state, together with such tariff sheets and circulars as were necessary to make the system complete. In August the leading railroads of the state were served with a printed notice of this uniform classification, and requested to show cause why the classification should not be put into effect. The carriers answered at considerable length, contending that the putting into effect of this classification would result, as in the previous case of the prescribing of storage, demurrage, and car-service charges, in a violation of the commerce clause and the Fourteenth Amendment of the Constitution of the United States, and urging, in addition, that their freight revenues would be unreasonably diminished thereby. Then followed many months of testimony taking, extending through 1906 and well into 1907. The final upshot of the matter was that the commission,

'Lake Shore, etc., R. R. vs. Ohio, 173 U. S., 285-297; Cleveland, etc., Ry. Co. vs. Illinois, 177 U. S., 514, 516; Louisville and Nashville Ry. Co. 2's. Kentucky, 16I U. S., 677.

-Atlantic Coast Line and Ry Co., etc., vs. The Commonwealth of Va., $102 \mathrm{Va}$., 599.

Report of Corporotion Commission, 1904, p. 61 . 
fully persuaded of the necessity of a uniform classification for the skillful exercise not only of its rate-making power but also of its supervisory authority, issued an order April 27,1907 , prescribing a single uniform classification for the freight traffic of the leading railroads of the state. No objection was interposed by these roads, even though, in the main, the level of freight rates was somewhat lowered thereby, and on October 15 th the order quietly took effect. ${ }^{3}$

In the meantime, history of far greater interest was being made in another sphere of activity. The whole of the United States ever since about the beginning of the Roosevelt period had been in a state of public unrest and legislative activity. In 1906 and 1907 came the culmination in the form of a veritable "crusade" against the railroads. In harmony with the general movement, the legislators of Virginia enacted, early in 1906, the so-called Churchman Act which, in brief, directed the corporation commission to prescribe a schedule of passenger rates for all transportation companies in the state and provided that, pending this action, all steam transportation companies were to keep on hand, at every station, mileage books of 500 miles or over, to be sold at a maxinum rate of two cents per mile, to be valid for use by any member of the purchaser's family, and to be redeemable as regards the unused portion. Several of the steam railroads failed to comply with the requirements of this act. ${ }^{2}$ The commonwealth thereupon picked out one of the offenders-The Atlantic Coast Line Railroad Company-and haled it before the commission.

The railroad set up two main grounds of defence: first, that the commission had the exclusive power, under the state constitution, of prescribing transportation rates, and

Report of Corporation Commission, 1907, p. 112.

" Virginia Low Register, vol. xv, p. 177. 
that therefore the general assembly had acted without authority in attempting to fix such rates; and second, that the Fourteenth Amendment of the United States was violated by the act in question, inasmuch as its enforcement would deprive the defendant of some of its property without due process of law.

The commission, disregarding the important issue raised in the first objection, and very carefully avoiding an expression of opinion on the delicate question of the legislature's constitutional right to prescribe railroad rates, chose to base its decision on a rather minor point. It held the requirement permitting mileage to be sold at two cents a mile, if in blocks of five hundred or over, while exacting more than two cents a mile from purchasers of any mileage less than five hundred miles, to be in direct contravention of the Fourteenth Amendment, which provides that no person shall be denied the equal protection of the laws; and accordingly dismissed the complaint of the commonwealth. As to whether the act would have been upheld had it applied to the sale of mileage regardless of the amount, the commission declined to express an opinion.

An appeal was straightway taken by the state to the state Supreme Court. In November, 1906, that tribunal, in a decision which very ably reviewed the whole subject of rate regulation, took the same stand as that adopted by the commission and upheld the latter's determination in favor of the railroads. ${ }^{1}$

The general assembly, it will be remembered, in its act of March I5, I906, had directed the commission to prescribe a schedule of passenger rates for all the transportation companies doing business in Virginia, and had merely intended its own rates to remain in effect until such action had

\footnotetext{
${ }^{1}$ Commonwealth vs. The Atlantic Coast Line Railroad Co., 106 Va., 61.
} 
been taken. The commission, in all probability, was not bound by this resolution, for the constitution of Virginia expressly prohibits the legislature from regulating rates. In obedience, however, to what it deemed a popular demand, the commission served a notice in July on all the steam railroads operating in the state, fixing upon November I, 1906, as the date upon which they might file their objections to the prescribing of a maximum passenger rate of two cents per mile for intrastate Virginia traffic. The carriers appeared on the date appointed and filed the customary objections. ${ }^{2}$ To only one of them did the commissioners pay serious attention-the argument, namely, that a maximum passenger rate of two cents a mile was unreasonable and confiscatory. In order, then, to ascertain the principles by which this proposed rate should be judged, they made a careful examination of certain aspects of the railroad business in Virginia, such as the gross earnings of all the carriers on all Virginia business, both interstate and intrastate; the expense of conducting this business; the gross earnings from the purely intrastate business; the expense of conducting this business; and the fair value of the carriers' property used in all the Virginia business, and that used only in the intrastate business. $^{2}$

The conclusions to which the commission finally came were, first, that since the transportation of passengers is a business peculiarly responsive to reductions in the rate of fare, the income of the carriers would not necessarily be diminished through the introduction of the proposed rates, and, second, that even if their revenues were diminished thereby they would still not fall off to such an extent as to occasion an unreasonable decrease in net earnings. ${ }^{3}$ Con-

1 Report of Corporation Commission, 1906, p. 9.

Ibid., 1907, p. 83.

'lbid., 1907, p. 99 
sequently an order was issued, April 27, 1907, effective in July, prescribing a maximum rate of two cents a mile for the ten strongest railroads operating in the state, ${ }^{1}$ with a maxinum rising by easy stages to three and a half cents for roads with a particularly light passenger traffic. ${ }^{2}$

The provisions of this order, it will be observed, differed in two fundamental particulars from those of the Churchman Act of the previous year: they applied only to mileage within the state, and they applied to all mileage within the state. $^{3}$ The commission hoped in this way to avoid the pitfalls into which the Churchman Act had fallen.

But these hopes were soon dashed to the ground. On

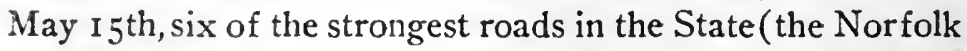
and Western, the Chesapeake and Ohio, the Atlantic Coast Line, the Chesapeake Western, the Louisville and Nashville, and the Southern) applied to Judge J. C. Pritchard of the Circuit Court of the United States for the Eastern District of Virginia for an injunction restraining the publication and enforcement of this order. The state, represented by Attorney-General Anderson, without attempting to demonstrate the reasonableness of the rates complained of, sought refuge in an act of Congress which forbids federal courts, except in bankruptcy proceedings, to enjoin the proceedings of a state court. The attorney-general declared, therefore, that since the Virginia corporation commission is a judicial court

'The Norfolk and Western Railway Co.; The Chesapeake and Ohio Railroad Co.; The Atlantic Coast Line Railroad Co.; The Seaboard Air Line Railway; The Southern Railway Co. (excepting three branch lines): The Richmond, Fredericksburg and Potomac Railroad Co.; The Washington and Southern Railway Co.; The New York, Philadelphia and Norfolk Railway Co.; The Virginia and Southwestern Railway Co., and the Louisville and Nashville Railroad Co.

2 Report of Corporation Commission, 1907, pp. 71-72.

- Virginia Law Register, vol. xv, p. 177. 
of record, the federal court had exceeded its jurisdiction in enjoining its proceedings.

These objections were overruled by Judge Pritchard on the ground that the commission, when it prescribes rates, cannot be recognized as a court, and he held that a federal court did have the authority to inquire into, and if need be, enjoin its proceedings. As no issue of fact had been presented to him, the only question raised having been one of law,-namely, the jurisdiction of the commission, he had no recourse under this ruling save to grant the injunctions desired by the companies.

While these injunctions were pending Governor Swanson of Virginia, with the approval of the commission, had proposed to the railroads that they allow the commission's regulations to go into effect on or before October Ist of that year, and to continue in effect until the final adjudication of the cases by the Supreme Court of the United States (for the commission had resolved, if beaten in the circuit court, to take the matter before the highest tribunal of the country. $)^{2}$ To this prudent suggestion four of the roads (the Chesapeake and Ohio, the Norfolk and Western, the Atlantic Coast Line, and the Southern) responded favorably. In a compact between the companies and the commission entered into on August 3 rd the former, for their part, agreed to put into effect the reduced rates prescribed by the latter, until the decision of the United States Supreme Court should decide as to the jurisdiction of the Circuit Court and the constitutionality of the commission. The latter, on its side, desirous of having its own status determined as soon as possible by the Supreme Court, and sensitive to the enormous expense and delay which another course would occasion. agreed to make no defense on the merits of the rates which

1 Report of Corporation Commission, 1007, p. 107. 
it had prescribed, and as soon as the final decrees had been entered, to take a prompt appeal to the United States Supreme Court. ${ }^{1}$ The stipulation was also made that in case the Supreme Court should deny the jurisdiction of the Circuit Court in the matter, but should uphold the constitutionality of the commission, the latter should permit the railroads to have another hearing on the reasonableness of the rates prescribed by it.

The cases were argued somewhat more than a year later, and were decided November 30,1908 , in an opinion, unfortunately very much involved, and far from satisfactory either to the railroads or to the state. The Supreme Court acknowledged the commission as a court, clothed with judicial as well as executive and legislative functions, and then went on to distinguish between legislative and judicial acts as follows:

a judicial inquiry investigates, declares and enforces liabilities as they stand on present or past facts, and under laws already supposed to exist. . . That is its purpose and its end. Legislation, on the other hand, looks to the future, and changes existing conditions by making a new rule to be applied thereafter to all or some part of those subject to its power. The establishment of a rate is the making of a rule for the future, and therefore is an act legislative and not judicial in kind.

Hence the court held that the making of rates by the commission is a legislative function, and that the circuit court is not exceeding its authority in the enjoining of orders prescribing those rates. Nay, further, even the proceedings of the Virginia Supreme Court of Appeals in the hearing and deciding of appeals from the orders of the commission in the fixing of rates may be enjoined by a federal court, for in such proceedings this highest court in Virginia is to be

'Report of Corporation Commission, pp. 104-107. 
regarded, not as a court, but as a legislature. In the words of the court, the question whether in any particular case the proceedings are legislative or judicial depends, " not upon the character of the body, but upon the character of the proceedings." The main contention of the commission, then, that a Circuit Court of the United States is without authority to enjoin its orders prescribing maximum rates, was held to be without foundation.

Upon the narrow ground, however, that the railroads had erred in coming before the Circuit Court for an injunction when they should rather have appealed from the commission's order to the Virginia Supreme Court of Appeals, as provided by the state constitution, the Supreme Court held that the Circuit Court, in this particular instance, had exceeded its authority, and therefore reversed Judge Pritchard's decrees. Had the Virginia Supreme Court, it added, been granted the opportunity of passing by way of appeal upon the commission's order, and had it sustained the latter's action, then the Circuit Court would have been justified in interfering on the side of the railroads by means of an injunction. For the Supreme Court of Appeals, in revising the order of the commission or in prescribing a new rate, on appeal by the railroads from the commission's order, would have necessarily performed a legislative function, so that the Circuit Court, if convinced of the unreasonableness of the rates prescribed, would have had a legitimate right to defer their enforcement through injunction proceedings. ${ }^{1}$

In very able and thoughtful opinions two of the most distinguished Judges of the United States Supreme CourtChief Justice Fuller and Justice Harlan - although concurring in the reversal of the decrees, yet dissented from

' Prentis vs. The Atlantic Coast Line Railroad Co., 211 U. S., pp. 210 et seq.; Report of Corporation Commission, 1908, pp. 5-7: Vir. ginia Law Register, vol. Xv, p. 179. 
the reasoning of the majority. They were of the belief that the Virginia corporation commission and the Virginia Supreme Court of Appeals do not lose their status as courts through the fixing of rates by the former or the hearing of appeals from the commission's orders by the latter, and that therefore Judge Pritchard had acted without authority in staying proceedings of the commission by injunction, for by section 720 of the United States Revised Statutes a court of the United States is expressly forbidden to enjoin the action of any state court.

Immediately upon the handing down of the decision several of the railroads attempted to appeal to the Virginia Supreme Court of Appeals from the commission's order of April 27, 1907, intending, in the event of an unfavorable outcome, to secure relief through new injunction proceedings in the United States Circuit Court. A Virginia statute, however, limits the time within which an application for appeal may be made to six months from the date of the adverse ruling; and as this limit had long since expired, the application had of necessity to be refused.

Shortly thereafter, four of the companies which had been plaintiffs in the injunction suits,--the Atlantic Coast Line, the Chesapeake and Ohio, the Norfolk and Western, and the Southern, together with the Seaboard Air Line, filed petitions before the commission, declaring that the maximum rate of two cents a mile which had been in force for over a year under the agreement of August 3, 1907, had proved inadequate and unremunerative, and at times, even confiscatory. ${ }^{2}$

To these petitions the commission granted a full hearing and extensive consideration. It declared, without reservation, that it did not intend to enforce, nor had it ever had

1 Report of Corporation Commission, 1909. pp. vi, 29. 
the intention of enforcing, rates so low as to prove inadequate and unremunerative to the railroads. With approval it quoted the words of a recent decision of the United States Supreme Court ${ }^{3}$ to the effect that the owners of railroad properties which are serving the public, and which are fairly and economically operated, have a legitimate right to an income from these properties sufficient to pay reasonable dividends and provide for repairs and replacements, so that the value of the property invested may be kept unimpaired. In addition it held that the owners are "entitled to a fair and reasonable income upon the value of the property employed in the public service." What that fair and reasonable income might be in the cases under consideration, it was unable to say, nor did it think that it will ever be possible to determine upon any certain specific percentage that will pass as reasonable at all periods and under all circumstances. ${ }^{2}$

When the commission introduced its lower fares in 1907 , it was in the expectation that the revenues of the various companies, if, indeed, they showed no increase, would at least not suffer a serious decrease. This expectation, however, had not been realized, for the number of passengers had not grown to the extent anticipated. In one particular, however, there had been a large, and, in the eyes of the commission, a very reprehensible increase. In nearby states such as North Carolina, South Carolina, and Tennessee, and in the District of Columbia the maxinum intrastate fare was, and had been for some time, two and one-half cents a mile. The interstate rate was the same. The practice had grown up, accordingly, in the case of interstate passengers, of buying tickets to the stations in Virginia nearest to the

1212 U. S., p. 1.

Report of Corporation Commission, 1909, p. 29. 
boundary line, of crossing the state to within a few miles of the opposite boundary line on a ticket costing but two cents a mile, and then of continuing their journey to another state at the interstate rate of two and a half cents. The commission felt that such a practice was extremely unfair to the Virginia railroads, and believed, further, that interstate and intrastate rates throughout the South should be made uniform. ${ }^{1}$

Another consideration, also, inclined the commission toward a sympathetic hearing of the railroads' petitions. In the words of the report,

since no large business interest can be injuriously affected without injuring the community as a whole, we believe that the failure of the railways to prosper so forces the reduction of the number of their employees and their wages, so reduces the ability and disposition of the railway companies to enter into new contracts for extensions, betterments and improvements, so curtails their power to purchase supplies of many kinds, thus affecting many other enterprises whose prosperity depends upon the purchasing power of the railways, and so discourages the investment of capital in new as well as old railway enterprises, as to amount to a public misfortune. Neither the right of the public to demand good service nor the right of the public service corporations to earn, if possible, a fair return upon the value of the property devoted to public service, should be overlooked. ${ }^{2}$

In the opinion of the commission, the majority of the disputes at that time in progress between public service corporations and the public authorities were traceable to a failure on both sides to acknowledge the justice of these well-established principles.

In view, then, of these considerations, the commission

${ }^{1}$ Report of Corporation Commission, 1907, p. 30.

2/bid., 1909, pp. 32-33. 
acceded to the wishes of the petitioning railroads, and increased the maximum passenger rate to two and one-half cents a mile. The roads, however, were required to continue the sale of mileage books at the old two-cent rate, in order that the needs of the public might not unduly suffer. These mileage books are still on sale at this rate, and the commission does not purpose, nor has it ever purposed, to allow them to be withdrawn without its consent. ${ }^{2}$

In 1910 the Washington Southern Railroad, and in 1911 the Richmond, Fredericksburg and Potomac Railroad were permitted to put into effect a maximum rate of two and onehalf cents a mile for the intrastate transportation of passengers in Virginia, continuing, of course, their mileage books and commutation rates at the old rate of two cents a mile. The commission made these changes, in spite of the fact that both roads were making money at the two-cent rate, for the purpose of rewarding these carriers for the economical and yet creditable manner in which they had conducted their business, and of placing them on a basis of equality with the other standard roads of the state, which for some time had been enjoying a maximum rate of two and one-half cents. ${ }^{2}$

During the past few years there has been remarkably little friction between the railroad corporations and the general public. There have been but few judicial hearings, "because of the settled policy of the commission to adjust all complaints by mediation if possible." " The commission

I Ibid., 1909, p. 2. The railroads affected by this order were the Norfolk and Western Railway, the Seaboard Air Line, the Chesapeake and Ohio Railway, the Atlantic Coast Line, and the Southern Railway.

Report of Corporation Commission, 1910, p. 12; ibid., 1911. pp. 17. 20. In 1908 the Virginia and Southwestern Railway Company had been allowed to put into effect a maximum rate of three cents a mile.

Ibid., I909, p. 6. 
appears to have well served the purpose for which it was created. The railroads are favorably disposed toward it, because its members are experts who are familiar with the technique of railroad matters, and who are far more likely to do them justice than a slowly-moving and poorlyinformed state legislature, and because, further, every single judicial act of the commission is appealable to the Virginia Supreme Court (which is not true of proceedings in any other court of the state). The general public is heartily in favor of its work, for it knows that shippers are now protected as well as can be expected against railroad oppression. The state now exercises a complete and effectual control over the railroads, and is capable of the promptest action against them, should they attempt to overthrow the safeguards which have been so carefully erected. 


\section{CHAPTER VII}

\section{Soutil Carolina}

\section{The Advisory Commission}

TuE first bills in the legislature of South Carolina looking to the regulation of railroads through some sort of commission appeared nearly simultaneously at the beginning of the session of 1878 . For those reported in the senate a substitute bill was returned by the committee on railroads, recommending the adoption of a law similar to that which had been but recently enacted by the state of Virginia. While this matter was under deliberation, the house passed a bill with much more stringent features. ${ }^{1}$ The senate then took this up, stripped it of its harsher provisions and returned it to the house. Upon the refusal of the latter to concur in the amendment, a conference committee was appointed which decided nearly every point in favor of the senate, ${ }^{2}$ so that the law finally enacted was a most conservative measure. It simply made provision, after the Virginia fashion, for one commissioner, appointed by the governor for a term of two years, whose business it should be to exercise a general supervision over the railroads, to examine their condition from time to time, and to recommend in his annual report to the legislature such changes in the law as he should deem advisable. ${ }^{8}$

Senate Journal, 1878, pp. 43 and 82: House Journal, 1878, pp. 1.40, 197.

'Senate Journal, 1878, pp. 222 and 242; House Journal, 1878, pp. 280, Df, 309 .

- Laws of 1878 , pp. $789-92$. 39.51 
When General Bonham in 1879 entered upon his duties as the first commissioner, he found affairs in a most undesirable state. As regards rates and fares, for example, there was the greatest confusion: some roads were bound by specific charges set forth in their charters; others enjoyed the privilege of charging up to a certain maximum; while in the case of other roads there were virtually no restrictions at all. ${ }^{1}$ Again, many roads were not keeping their accounts in the form prescribed by law; while still others were either making absolutely no return of the year's operations to the legislature, or were doing it in a very incomplete manner. ${ }^{2}$

Against these difficulties the commissioner struggled manfully, and yet with little success. The utmost that he could accomplish was to secure some improvement in the form and regularity of the annual returns of the carriers, ${ }^{2}$ and some progress in the betterment of their structures and equipment. ${ }^{3}$ The railroads, now responsible by law for the payment of the expenses and salaries of the commissioner's office in proportion to their gross receipts, were lax, even, in that regard, so that he was frequently embarrassed by the non-payment of these assessments. ${ }^{4}$

No wonder, then, that from the very start the commissioner pleaded with the legislature for some relief from these difficulties. In his report for 1879 he recommended that " so far as the legislature can do so, uniform maximum rates be adopted for all the railroads in the state." " In the report for $188 \mathrm{I}$ he went so far as to suggest that the

1 Report of Railroad Commissioner, 1880, pp. 21-22.

2 Ibid., I88I, p. 15.

Ibid., 1880, p. 10.

'Ibid., 1880, pp. 15-16.

- Ibid., 1879, p. 6. 
system prevailing in Georgia be adopted, whereby power should be conferred upon three commissioners to regulate the freight and passenger tariffs of the South Carolina railroads. ${ }^{1}$

\section{The Mandatory Commission}

These reconmendations were not without their effect upon the legislators, the more so as General Bonham had been prominent for many years in the affairs of the state. At the session of $1879-80$ and again in the special session of 1880 bills were introduced conforming to his proposals; but they failed to get beyond a second reading. ${ }^{2}$ Success, however, was complete and speedy at the next meeting of the legislature. A bill reported from a joint select committee, and clothing the proposed commission with practically the same powers as those enjoyed by the Georgia commission was quickly carried through the senate. ${ }^{3}$ The house returned the bill with certain amendments, and the senate not concurring, a conference committee took hold of the matter. The senate rejected its report, however, and induced the house to consent to the appointment of a committee of free conference, where, finally, the lower chamber gave way. The South Carolina law, ${ }^{\circ}$ then, was practically a copy of the Georgia statute. General Bonham, Mr. Jeter -a former railroad president-and Mr. Walker were named as the members of the new commission.

Before entering upon their work they visited the Georgia

1 Report of Railroad Commissioner, 1881, p. 17.

'House Journal, 1879-80, p. 36; ibid., 1880, p. 456; Senate Jourmal, 1880, p. 246.

- Senate Journal, 1881-82, p. 2a4.

- Ibid., I881-82, pp. 503, 528, 548-49, 681-82; House Journal, 1881-82,

p. 536, and Charleston Neu's and Courier, Dec. 21, 1882.

- Laws of 1882, pp. 10-19. 
commissioners in Atlanta and obtained from them information of the greatest value, inasmuch as the laws creating the two commissions were fundamentally alike. Upon their return they set about the task of bringing order out of the existing chaos. The greatest irregularity among the different carriers was still rampant, each road having its own method, or rather lack of method; and to add to the confusion, there was no uniform classification of freight for the various railroads serving the state.

After some months of investigation the commission prepared and submitted to the carriers a standard schedule of passenger and freight rates and classifications. For interstate freight traffic the railroads were permitted to continue the use of the Southern Railway and Steamship Association Classification, the standard freight tariff being made applicable to intrastate tonnage only. ${ }^{1}$ Regarding charges, maximum rates were established for each road, based upon the principle of distance alone, and without reference to direction of movement or to the point of shipment or destination. ${ }^{2}$ Any reductions from those maximum rates were required to be uniform and non-discriminating in their effect. As a result the rates for long distances were but little changed,-reduction-as was to be expected-coming mainly in the charges for short distances. ${ }^{3}$

As to passenger rates, the railroads were grouped in three classes, with a maximum fare of three cents per mile for the eight supposedly strongest railroads of the state, a maximum of three and one-half cents per mile for most of the others, and a maximum of four cents for the rest. ${ }^{4}$

' Report of Railroad Commission, 1883, pp. 7, II.

'Ibid., I883, p. 5.

- Ibid., I883, p. 8.

I Ibid., 1883, p. $1 \mathrm{I}$. 
As was soon discovered from the reports of the railroads, this tremendous reduction in rates went entirely too far, and proved that the commissioners, in their efforts to bring some sort of unity out of the existing disorder, had acted without a proper regard for the rights of these corporations. The rates had been in operation no longer than three months when the legislature felt obliged to quiet the clamor of the carriers. The commission's rates were amended to read as follows : a maximum of three cents per mile for those roads, only, whose passenger earnings were exceeding $\$ 1,200$ per nile per annum ; a maximum of three and one-half cents for roads with earnings between $\$ 700$ and $\$ 1,200$; and correspondingly higher rates for the other railroads. ${ }^{1}$ The result of this act, of course, was to increase rates greatly in comparison with those prescribed by the conmission. Only two roads, for example, were now left in the three-cent class, and only three in the three and one-half cent division.

Vigorous complaints, also, in regard to the schedule of freight rates imposed upon them by the commissioners were made by the carriers to the legislature. The drastic provisions of the law had withheld from the roads the right of an appeal to the courts irom the rate decisions of the commission, and it was but natural for them to petition the legislature for relief. And this was not slow in forthcoming, for at the very next session the suggested amendment was passed, with the further provision, even, that the railroads might make their own rates, subject to the approval of the board. Very sensibly, however, it was added that in the case of an appeal from the commission to the courts the rate objected to by the railroad was to remain in force during the length of the appeal, and was not to be changed untit after a decision favorable to the road. ${ }^{2}$

- Report of Railroad Commission, 1884, p. 7 : Laws, 1884, p. 759.

2 Ibid., 1884, p. 5. 
The consequence of this legislative encroachment upon the domain of the board of railroad commissioners was the development of greater harmony between the people and the railroads than had been known for many years before, ${ }^{1}$ a harmony, however, that never would have arisen so early had the commission been allowed to go unrestrained in its rather hasty and ill-considered work of regulation. This good feeling was shortly increased by further concessions to the carriers. First, the commission did what it should have done at the outset, and applied the classification of the Southern Railway and Steamship Association,-with a small exception sheet, to be sure,-to intrastate as well as interstate traffic. Then the legislature further raised the average of passenger fares within the state by providing that the maximum of three cents per mile should apply only to those roads whose earnings were exceeding $\$ 1,800$ per mile per annum, with corresponding increases in fare for the other roads. ${ }^{2}$ As a result, not one carrier was left in the three-cent class, and fares were placed at a level where they would once more yield a fair return. In view of the sparseness of the population and of other conditions, a fare of four or of four and a half cents a mile was but a reasonable charge for the majority of the South Carolina railroads of that day to exact from the traveling public.

Since the strife of those early years there has been but little controversy, comparatively speaking, between the commission and the railroads. In the main, the recommendations and regulations of the commissioners have been accepted without dispute by the carriers, so that resorts to the courts by either side have been most infrequent. This result would appear, moreover, to have been due as much to

1 Report of Railroad Commission, 1884, p. II.

'Ibid., 1885. pp. \&-10. 
the forbearance and patience of the one as to the good sense and compromising spirit of the other.

When the commission law was passed the expediency was not then recognized of putting under the jurisdiction of the board the matter of joint rates as opposed to rates on tonnage moving over one railroad merely. But with the tremendous increase of traffic in the late eighties joint rates came uppermost in the minds of the commissioners, and after repeated recommendations ${ }^{1}$ for control over these rates the requisite authority was finally conferred by the legislature in $1893 .{ }^{2}$

By the same act the prescribing of maximum rates of passenger fare was restored to the commissioners, from whom it had been taken in $\mathbf{1 8 8 4}$. They hastened at once to make use of their power by reducing the maximum for all roads to four cents or less per mile. ${ }^{3}$ The carriers, of course, were now in a better condition than they had been ten years previously to withstand the effects of this reduction, though in view of the panic of 1893 and of the accompanying years of distress the action of the board was, to say the least, rather premature. And by 1897 the maximum rates for the principal lines had been still further reduced to three and one-quarter cents per mile."

As the tonnage of any particular business increased, reductions, as seemed warranted, were made by the commission in the carrying charges. In 1899 , for example, the cotton tariff, which had not been changed since its issue in I886, was subjected to a careful revision."

'E. g., Report of Railroad Commission, 1891, p. 10.

- Laws, ch. xv, title xii, sec. v.

- Report of Railroad Commission, 1893, pp. 16, 99.

- Ibid., 1897, p. 7.

Ibid., 1899, p. 10. 
In 1903 the Southeastern Freight Classification was adopted as the official classification of the state, on the ground that the freight tariffs would thereby become more intelligible to the public. ${ }^{1}$

Late in that year a complaint was filed by the Charleston bureau of freight and transportation and by other bureaus to the effect that the intrastate rates in South Carolina were unreasonably high and oppressive, and petitioning, therefore, for a reduction. Investigation of this complaint by the conmission went on for nearly a year, when the situation was found to be as follows:-freight rates in South Carolina, on the whole, were lower than in Virginia and but a trifle higher than those prevailing in North Carolina and Georgia; while passenger rates were lower than in either Virginia or North Carolina, and about the same as those in Georgia. The complaint was accordingly dismissed. ${ }^{2}$

When defects in the commission law have made themselves manifest, the board has urged upon the legislature the desirability of their removal. Scattered through the pages of reports for the past twenty years are recommendations, for example, for the authority to make commodity rates, ${ }^{8}$ for the provision of special legal counsel, ${ }^{4}$ for the appointment of an inspector of railroads, ${ }^{5}$ and so on. As usual, the legislatures have been too busy with their own projects to pay much attention to these appeals.

South Carolina was remarkably free from litigation of the character that involved most of the other southern states

' Report of Railroad Commission, 1903, p. 17.

'Ibid., Ig04, pp. II, 22.

"Ibid., 1902, p. 14; 1903, p. 16; 1904, p. 34.

- Ibid., 1907, p. 12; 1908, p. 20 ; 1909, p. 18.

'Ibid., 1907. p. 12; 1908, p. 20; 1909, p. 18; 1913. p. II. 
from 1907 on in their efforts to establish lower passenger rates. As a result of conferences between Governor Ansel and the commission, on the one hand, and the railroads, on the other, the three leading roads in South Carolina (the Southern, the Atlantic Coast Line, and the Seaboard Air Line) voluntarily put on a flat passenger rate of two and one-half cents a mile and issued mileage books at the rate of two cents a mile. ${ }^{1}$ The commission thereupon extended the two and one-half cents rate to three of the other carriers operating in the state. ${ }^{2}$ This was in 1908.

An unfortunate controversy soon developed, however, over the new requirement by the railroads abolishing the "pulling" of mileage on trains and requiring its exchange for passenger tickets at ticket offices. The commission has no authority over the sale of mileage books, and its efforts at compromise were of no avail." The legislature, in I9I I, enacted a law requiring the acceptance of mileage by conductors on trains. The railroads retaliated by withdrawing their interchangeable mileage books and substituting individual intrastate books. They will not accept mileage from their interstate, interchangeable books for any part of a journey within the state, so that to avail oneself of the privilege of mileage-book travel throughout South Carolina one must purchase four mileage books (one from each of the four strongest companies) at an outlay of eighty dollars."

In November, 1912, the commission submitted the question to the Interstate Commerce Commission, alleging dis-

I Senate Journal, 1908, p. 188; ibid., 1909. p. 39; Report of Railroad Commission, 1908, p. 4.

Ibid., 1908, pp. 6-7.

Ibid., 1908, pp. 9-10.

1 lbid., 1912, pp. 10-11. 
94 REGULATION OF RAILROADS IN THE SOUTH [404 crimination by the railroads against South Carolina, and requesting the passage of a uniform rule or regulation covering the entire mileage-book question. ${ }^{1}$ Hearings were held in Charleston and in Washington, at the conclusion of which the Interstate Commerce Commission refused to grant the relief demanded. The South Carolina commission thereupon submitted the question to the legislature. ${ }^{2}$

1 Report of Railroad Commission, I912, p. II.

'Ibid., 1913, p. 10. 


\section{CHAPTER VIII}

\section{Georgia}

\section{The Railroad Commission to 1907}

THE question as to the desirability of a commission to supervise or regulate the railroads in Georgia appears not to have arisen until the comparatively late period of the waning seventies. In the summer of 1877 a constitutional convention met in Atlanta for the purpose of revising the fundamental law of the state, and it was there that the subject of railroad regulation received its first general discussion. When the report of the committee on finance, taxation and public debt was laid before the convention it was found to contain a clause wherein the duty was laid upon the legislature of enacting legislation looking to the abolition of unreasonable rates, extortion, discrimination, and the like. A lengthy and spirited consideration of this issue then followed. The general sentiment soon displayed itself as favoring some sort of regulation. Finally a substitute proposed by Mr. Reese was adopted in lieu of the original paragraph,' and incorporated in the constitution as follows:

The power and authority of regulating railroad, freight and passenger tariffs, preventing unjust discriminations, and requiring reasonable and just rates of freight and passenger tariffs, are hereby conferred upon the General Assembly, whose duty it shall be to pass laws from time to time, to regulate

- Proceedings of the Constitutional Convention of Georgia, 1877. pp. $378,385-410,466$. 
freight and passenger tariffs, to prohibit unjust discriminations on the various railroads of this state, and to prohibit said railroads from charging other than reasonable and just rates, and enforce the same by adequate penalties. ${ }^{1}$

No provision in express words, it will be noticed, was made for the establishment of a commission.

Great caution and care were exercised in the carrying out of these constitutional provisions. Committees of both houses had the matter long under advisement, both during the following legislative session and in the vacation thereafter. Discussion was invited from business and railroad men; and leading citizens were freely consulted during the preparation of the bill. The measure that resulted, therefore, was " no violent and indiscreet action, made recklessly and in haste, but was a carefully considered act, so framed as to gauge the powers of the commission in order to adapt them to the protection of all interests." 2

When the session of 1879 opened, sentiment throughout the state was developing very rapidly in favor of the creation of a railroad commission. Even experienced railroad men, either through communications in the press or in statements before the two railroad committees, appeared as sponsors for a commission clothed with ample power, while held to a rigid performance of the duties required of it. $^{3}$

For the flood of bills introduced in the house under the railroad clause of the constitution the house committee on railroads reported a measure with provisions as drastic, perhaps, as those of any commission law in the country at that time. In little more than a week this bill passed the house and came up for consideration in the senate. The

${ }^{1}$ Georgia Constitution, 1877, art. iv, sec. xi.

2 Third Report of Railroad Commission, 1881, p. 10.

3 Atlanta Constitution, July 17, 1879; Railroad Gazette, Oct. 24, 1879. 
upper chamber thereupon adopted a measure of its own of a milder character. Then followed the usual deliberations in conference committee. In the end the whole matter was settled by the giving way, in the main, of the senate. ${ }^{3}$

The creation of a carefully constituted commission was hailed as the solution of the whole matter. The impression seemed to be that the decisions of such a body

would result in the true and exact principles of justice that lie at the bottom of this question, upon which could be based a code of laws so just in their application and so wise in their operation that never again would there ever seem to be any conflict between the interests of the railroads and the rights of the people."

The statute made provision for a commission of three members, appointed by the governor with the consent of the senate. The term of office was fixed at six years-an admirable improvement upon the American practice at that time of short terms-with the proviso that in the case of the commissioners first appointed one should retire at the end of two, and another at the end of four, years. The restriction of the law also required that one should be a lawyer, another a railroad expert, and the third a man of affairs.

Upon the commissioners there was bestowed an almost unprecedented authority. They were given the power to investigate the books and papers of the companies, to subpoena and examine witnesses, and to make any other examinations necessary for the purpose of ascertaining whether the rules and regulations against extortion and unjust discrimination

2 Railroad Gasette, July 31, 1879; Senate Jowrnal, 1879, pp. 364, 565. 568, 635; House Journal, 1879, p. 1996; Laws, 1878-79, art. no. cclxix, part $\mathrm{i}$, title xii.

- Allonta Constitution, Sept. 12, 1879. 
were being violated. All arrangements between carriers as to rates of transportation or respecting a division of earnings by competing roads were to be submitted to the commission for examination and approval. Semi-annual reports were to be made to the governor, covering in detail the operations of the roads for the period preceding, and based upon the returns which the railroads were now required to file with the board in a systematic manner.

Regarding the all-important matter of charges for intrastate traffic-interstate traffic being acknowledged as beyond supervision-the commissioners were clothed with rather arbitrary powers. The duty was laid upon them of making " reasonable and just" rates of freight and passenger tariffs, and "reasonable and just" regulations for the prevention of abuses such as extortion, unjust discrimination, and the like. They were also to prepare schedules of " reasonable and just" rates for the different carriers, such schedules to be "sufficient" (and not merely prima facie) evidence in the courts that the rates therein fixed were just and reasonable. These schedules were to be published in the papers of the leading cities of Georgia for at least four successive weeks before going into effect. Violations of the rules and regulations of the commission were made punishable by fines of from $\$ 1000$ to $\$ 5000$, to be recovered through actions in the county courts instituted in the name of the state by either the attorney-general or solicitor-general. ${ }^{1}$

Where so much authority was vested in the hands of only three men, the personnel of the board was of fundamental importance. Governor Colquit rose to the occasion. Disregarding the pressing appeals of scores of candidates, some of them capable and some not, he selected three men of as fine a reputation as could be found in all Georgia, and not one

${ }^{1}$ Laws of Georgia, 1878-79, pp. 125-131. 
of whom, so far as could be learned, had made application for the positions. Former Governor Smith, a leading lawyer of the state; Mr. Barnett, an accomplished publicist and man of business; and Major Wallace, one of the most prominent railroad men of the South, were the gentlemen whose appointment was " received with unqualified satisfaction all over the state." "

With the two chief objects of the law-the prevention of extortion and of unjust discrimination-in view, the commission set to work to "do equal and impartial justice to both railroads and people". An examination of the passenger tariffs of the roads operating in Georgia revealed an average rate of from five to six cents a mile. Deeming these tariffs much too high the commissioners reduced those of the most important carriers to a maximum of four cents a mile, with corresponding reductions for the other roads. Experience soon proved that the increase in travel occasioned thereby was adding materially to their earnings. The question as to the reduction of passenger charges below the maximum fixed by the board was left with the carriers themselves, since the law placed no restrictions upon reductions of this sort. ${ }^{2}$

The desirability of a standard freight classification was apparent to all. One of the first duties of the commission. therefore, was the preparation and promulgation of such a classification. The rates then in force upon the Western and Atlantic Railroad were used as a basis upon which to construct a standard tariff. Percentages upon this standard were prescribed for all other roads corresponding to the business being done and to their general condition. The result was a material reduction in freight rates over the

' Atlanta Constitution, Oct. 16, 1879.

2d Report of Railroad Commission, 1880, p. 5. 
former figures, a reduction applying principally to the chief articles of production and consumption. ${ }^{x}$

From time to time reductions were made in the maximum passenger tariffs of various railroads, experience proving that the revenues of these roads, far from being diminished by reductions were, on the contrary, somewhat augmented through the increased volume of travel. By the end of 1882, nearly all the Georgia carriers had been restricted to a maximum charge of three cents per mile. ${ }^{2}$

These reductions in freight and passenger rates were not made without vigorous opposition on the part of the railroads. The most famous case was that brought by the Georgia Railroad and Banking Company. A bill was filed by this company in 1882 against the commissioners for an injunction against the enforcement of certain rates of freight prescribed by the commission. The main ground of complaint was that the company was authorized by its charter to charge certain other rates-higher, of course, than those fixed by the commission-and that the legislature could not legally take this constitutional right away. The injunction was denied, however, and on appeal first to the state Supreme Court and then to the United States Supreme Court the decision of the court below was affirmed. ${ }^{3}$ The legality of regulation of railroads in Georgia, therefore, was now definitely established, so that the commission was enabled henceforth to proceed the more vigorously in its course of supervision and control.

In 1885 the carriers announced their purpose of seeking legislation at the approaching session of the general assem-

'2d Report of Railroad Commission, 1880, p. 5; ibid., 2Ist Report, 1892-93, p. 6.

${ }^{2} 4^{t h}, 5$ th and 6th Reports (combined) of Railroad Commission, 1882, p. 7.

- Railroad Gazette, March 2, 1883; 128 U. S., p. I82. 
bly that would so amend the law of 1879 as to make it more consistent with their views and wishes. They alleged, first, that the very existence of the commission was injurious to the public interest, inasmuch as the introduction of capital into the state for the building and equipping of railroads was virtually at a standstill from fear that the commissioners might so exercise their powers as to render such investments valueless. The commissioners answered with the following statement of facts: (1) Six times as many miles of railroad had been built during the first five years of the commission's life as had been built in the five years prior to its creation: (2) more of the stock of roads operating in Georgia had been purchased by foreign capital and at higher rates from 1879 to 1885 than at any like previous period; (3) non-resident capitalists had purchased the control of three Georgia roads; and (4) Georgia stood second among the states south of the Ohio and east of the Mississippi rivers in the amount of mileage constructed during the first six months of $1885 .^{2}$

The railroads alleged, in the second place, that the execution of the law by the commission had so impaired their credit as to depress the value of their stocks considerably, and to make it almost impossible to place new bonds for the redemption of their old ones. In reply to the former accusation the commissioners stated that instead of a depreciation there had really been an appreciation in the value of Georgia railroad stocks, and this, too, in spite of the general depression in business. As for the bonds, the board demonstrated by a table that those of most of the companies had undergone absolutely no loss in value since $1879^{2}$

The railroads were unable to assail successfully the cor-

IIth Report of Railroad Commission, 1885, pp. 3, 6.

Ibid., 1885, pp. 7-10. 
rectness of these statements, and the threatened legislation never developed into law. "It will at least be conceded," said the commission a few years later, "that the commission has not . . . thrown even a pebble in the pathway of our noble state in her triumphal march to wealth and prosperity." 1

In 1887 the standard freight tariff and classification, which had not been revised since its promulgation in 1879 , was subjected to a thorough overhauling. ${ }^{2}$

The troublesome subject of joint rates was the next important question to concern the commission. In 1889, at the request of the board the legislature conferred upon it the unqualified "power to make just and reasonable joint rates for all connecting railroads doing business in this state as to all traffic or business passing from one of said railroads to another ". ${ }^{3}$ The power thus granted was exercised the following year. But the rule had not been long in operation before the commission was convinced that it was practically being disregarded by the carriers. The railroads, on the whole, simply refused to conform their charges to the regulation of the board, knowing that not one shipper in a hundred was aware of the exaction of the illegal charge. Whenever complaint was made to the commission the offending railroad promptly refunded the overcharge-amounting, in some cases, to but a few dollars; and having thus disposed of that particular complaint, continued its extra-legal policy as before. The proportion of overcharges thus refunded was deemed by the commission to be but trifling in comparison with the aggregate amount illegally collected. The legislature was accordingly appealed

${ }^{1}$ I6th Report of Railroad Commission, 1887-88, p. 9.

2 Ibid., I5th Report, 1887, p. 5.

'Laws, I889, pp. 131-32. 
to for the enactment of a law by which the board might institute an action to secure the penalty provided by law, without giving the railroad any notice to make reparation.' The general assembly quickly responded in the manner suggested." The commissioners, of course, proceeded cautiously in the exercise of their new power, taking action in cases, only, where they were satisfied that the violation of their regulation was wilful and intentional. The consequence was that the railroads were soon stopped in their course of nullification, and that Georgia, perhaps more than any other southern state, thus early enjoyed the advantages derived from a vigorous administration of joint-rate rules and regulations.

Of the succeeding years of the commission's work up to the general reorganization of the board in 1907 there is little to relate. The carriers simply adapted themselves to a system which they were powerless to overthrow, and complaints by shippers and travelers as to intrastate traffic were comparatively few. The commissioners from time to time declared that in Georgia there was to be found what was "perhaps the best exemplification of government control of railroads to be found in the country":s

And yet the commission law, in the opinion of the board, was still very defective. So year after year, almost, it entreated the legislature for the grant of further authority: for power, for instance, over the issuance of stocks and bonds by the railroads; for the extension of its control over sleeping and parlor-car companies and over street and electric railways; and, chiefly, for the provision of legal ma-

1 19th Report of Railroad Commission, 1890-91, p. 6.

- Laws, 1890-91, vol. i, p. 147.

- 28 ih Report of Railroad Commission, 1899-1900, p. 3; ibid., 29th Report, 1900-or, p. 11. 
chinery to compel prompt compliance with its orders by the carriers. ${ }^{1}$ In Georgia, as in the other southern states, the only remedy for a violation of a rule or regulation or an order of the commission was to sue in the courts for a penalty. But there the action would drag along for months, the railroads thus continuing the wrong long after the commission had undertaken to rectify it. The board therefore sought repeatedly to be empowered to invoke the courts by the summary remedies of mandamus or injunction for the speedy enforcement of its orders and regulations.

Members of the commission went so far, at times, as to draw up and have reported in the legislature the necessary bills for the enactment into law of these recommendations. ${ }^{2}$ Notwithstanding their repeated efforts their pleas long fell on deaf ears, and it was not until the waves of the widespread agitation of 1906 and succeeding years broke upon Georgia that the recommendations of the commissioners were seriously taken up.

\section{The Railroad Commission since 1907}

By the provisions of the Candler act of $1907^{\circ}$ the railroad commission was almost completely reorganized, its jurisdiction being greatly extended and the duties imposed upon it largely increased. It was in reality transformed into a corporation or public utilities commission like that of North

1 23rd Report of Railroad Commission, I894-95, pp. 19-20; ibid., 1895-96, pp. 16-17; ibid., 1896-97, p. 14; ibid., 1898-99, pp. 13-21 ; ibid., I899-1900, pp. 9-10; ibid., I90I-02, pp. 4-7; ibid., 1902-03, pp. 4-7; ibid., 1903-04, pp. 7-9; ibid., 1904-05, pp. 8-1 I ; ibid., 1905-06, p. 3.

${ }^{2}$ E. g., House Journal, I891, p. I47; ibid., I892, p. 187; ibid., 1893, p. 286 ; ibid., I896, p. 527 ; ibid., I897, p. 464 ; ibid., I899, p. 178; ibid., 1901, p. 251 ; ibid., 1902, p. 124; ibid., 1903, p. 100 ; ibid., 1904, p. 271 ; ibid., 1906, p. 525 ; Senate Journal, I896, p. 190; ibid., 1902, p. 206; ibid., 1903. p. 68 ; ibid., 1905, pp. 198, 464, 606 .

'Laws, 1907, pp. 72-8I. 
Carolina or Virginia, possessing authority very nearly as extensive.

The most interesting feature of the new law was that which referred to the issue of stocks and bonds by the corporations under the commissioners' jurisdiction. The duty was laid upon the commission-for the first time in the history of commission regulation in the South-of promulgating such rules regarding the issuance of stocks and bonds as would both put an end to the evil of overcapitalization and assure to innocent purchasers and holders securities representing true, and not fictitious, values. The main purpose of the legislature, as in Texas, was to "squeeze" as much "water" as possible out of the roads operating in the state,-for they were, and still are, heavily overcapitalized as a result of loose construction methods, reorganizations, and so on. ${ }^{1}$ The commission has fixed certain rules which must be followed in petitions for the approval of an issue of securities, such as a full description of the railroad's property, a detailed statement of its financial condition, a recital of the amount and kind of stock or bonds (with the terms and rate of interest) and how secured, a statement of the use to which the capital secured is to be put, and the like. $^{2}$ As to the working of the law there is a lamentable lack of information in official publications. The reports of the commissioners, for instance, are nearly silent in this regard.

According to statements of the chairman of the commission, however, the working of the law has been very effective in practise, in spite of the fact that the board has no adequate accounting or engineering departments upon which to rely in the evaluating of proposed enterprises. Many an

Laws, 1907, no. cexxiii.

35th Report of Railroad Commission, 1906-08, pp. 47-50. 
over-capitalization project, he states, has been quashed by the refusal of the commission to indorse the highly speculative plans of promoters and others. If the commission is not satisfied with the proposals and showing made under the rules by petitioning companies, it requests them to have an audit and evaluation made by an engineer named by itself. However, the civil engineer attached to the commission, with the assistance of other departments of government, has now collected, and is still collecting, a large amount of data as to unit costs, rates, etc., which is proving of continually greater value in the matter of the approval or disapproval of security issues. ${ }^{1}$

As in other southern states the commission was considerably embarrassed for a while by litigation over the question of passenger fares. Just before the old commission went out of office in 1907 it promulgated an order reducing the rates of passenger fare on nearly all the railroads operating in Georgia. When the new commissioners came int's office they were petitioned by the railroad companies to revoke this order, or at least to extend the time of the reduction. After an "elaborate hearing" the commission declined to interfere in any way. Most of the companies yielded as a result of negotiation, while a few attempted to sue out injunctions. But no railroad was able to obtain the grant of even a temporary restraining order. ${ }^{2}$

There has been some agitation of late for a revision of the "port rates" of the state, $i$. e., for a revision of the charges for freight transportation from all interior points in Georgia to the ports, and from the ports to all interior points. For years, practically, all the roads extending from

1 Letter of Professor William A. Shelton, of the University of Georgia, to the author, January 4, 1916.

${ }^{2}$ Senate Journal, 1907, pp. II-13; 35th Report of Railroad Commission, 1906-08, pp. 14, 78. 
the coast into the interior have been under the control of railroads running north and south. These trunk lines have sought, of course, to divert to themselves traffic that would naturally move through the ports by maintaining a high level of rates to and from the ports. In this way they secure a greater portion of the through haul. When the membership of the commission was increased from three to five in 1907, it was understood by many that this increase was provided merely to secure a majority in that body in favor of a scaling down of these port rates. Yet in spite of appeals from the governor and others, all efforts to effect a "revision downward" have been defeated."

The most pressing need at present is a thorough and scientific revision of the freight classification and standard tariff, which, as they exist to-day, are largely antiquated and contradictory. ${ }^{2}$ But the commission, with the meagre funds at its disposal, hesitates to enter upon this expensive task. The same problem is before not a few of the other southern commissions.

' Senate Journal, 1908, pp. 18-21; 1911, p. 34; 1912, p. 57 ; House Journal, 1913, Pp. 50-51.

- Report of Railroad Commission, 1913, p. 13. 


\section{CHAPTER IX}

\section{KENTUCKY}

\section{THE ADVISORY COMMISSION}

THE first bill ever reported in the legislature with provisions looking to the establishment of a railroad commission appeared in the senate at the session of 1879 . This bill, called into life probably by the creation two years previously of the office of railroad commissioner in Virginia; followed very closely the outlines of the law of that state. It met with favor in both houses, and was quickly enacted into law. ${ }^{1}$ Provision was made for a commission of three members - one member representing the farmers, another the business interests, and the third the railroads-appointed by the governor, with the consent of the senate, for a term of two years. They were to examine into the condition of the roads; prosecute violations of the law-aided by the authority to inspect books and papers; issue subpoenas and examine witnesses; and make annual reports to the governor, based upon the returns of the carriers. ${ }^{2}$ A typical advisory commission, in other words, was thus established.

No sooner had the commission organized than complaints poured in from all parts of the state, and in many localities indignation meetings were held, at which resolutions demanding relief from extortionate charges were passed.

1 Senate Journal, 1879-80, pp. 690, 709; House Journal, 1879-80, pp. 1215, 1288, 1392; Report of Railroad Commission, 1881, pp. 205-06.

3 Laws, 1879. ch. mxix. 108 
These resolutions were forwarded to the railroads through the commissioners. The latter, after a lengthy survey of the situation, concurred in the belief that the prevailing freight and passenger rates were excessive, and urged a general reduction upon the roads. The railroads, however, did not look at the matter in this light, so that the most persistent hammering by the commission did little but secure from them a few reductions applying to certain localities only.'

The commissioners then called a conference of the railroad officials of Kentucky, and submitted the following propositions: An average reduction of twenty per cent upon all freight tariffs then in force; a reduction of passenger fares to a standard rate of three cents a mile; and no advances, in future, in freight rates, without a public notice of thirty days prior to the going into effect of the charges. ${ }^{2}$ As matters then were, tariffs were subject to the slightest fluctuations of the market, so that farmers and business men had the greatest difficulty in calculating ahead to any extent. $^{3}$

A comnittee of five railroad representatives was appointed to reply to these propositions. In due time a pamplilet was forwarded to the commission, in which the rates and fares on the various lines were upheld and the commissioners' requests rejected." Circular letters were thereupon mailed to the recalcitrant carriers, urging upon them the necessity of a reduction in their charges, and threatening them, in case of non-compliance, with an appeal to the legislature for more restrictive legislation. The response, as before, was very unsatisfactory. The Louis-

1 Report of Railroad Commission, 1881, p. 10.

Ibid., 1881, pp. 7-8.

Ibid., 1881, p. 103.

- Ibid., 1881, pp. 8, 11. 
ville and Nashville reduced its freight charges at a couple of points and two or three roads announced their intention of operating under a maximum passenger fare of three cents a mile; but there was no general reduction by the carriers such as the commission was striving for. ${ }^{1}$

The commissioners were convinced, for one thing, that

the power to persuade railroads by investigating and reporting requires a much longer time to consummate its purposes than it would if compulsory power was lodged in the hands of a commission in this state, as in Georgia, California and other states. $^{2}$ It will be well for us, they continued, to put aside the idea that the law of competition will prevail here in Kentucky as in the dry goods and grocery trade; the conditions are so different that we must seek something beside competition to bring us cheap transportation. .. . The law of competition does not, and will not, regulate transportation on railroads, and bring it down to a fair and reasonable basis. ${ }^{8}$. . . In Kentucky the ratio of competitive points to the non-competitive points, or, in other words, the area of country in which competition in railroad traffic brings rates down to a fair rate, or below it, as the case may be, stands to the area of country where competition has no effect, as one to twenty. In this state of case we get a fair rate or less for one-twentieth of the people, and nineteen-twentieths have to pay an unfair rate, and make up the deficit, if any, to the railroads where competition reduces the rate below a paying point. We are therefore shut up with but two avenues of escape-one is appeal to the "soulful sympathy" of corporations-the other by appeal to the legislature to do justice to the railroads and to the people it represents by vesting the right in a railroad commission to apply such enactments as to its wisdom may seem just and right."

'Report of Railroad Commission, 188r, pp. 31-33.

2 lbid., 1881, p. 14.

8 Ibid., I881, p. 24.

- Jbid., t88I, p. 26. 
These first commissioners, nevertheless, did a valuable work for the people of the state. They gathered and disseminated much useful information; they satisfactorily adjusted countless complaints; and they induced a number of the companies to reduce their passenger fares to a maximum of three cents a mile. Further, the able chairman of the commission, Mr. J. F. Johnston, ${ }^{1}$ impressed with the greater importance of the supervision of interstate, as contrasted with intrastate, commerce, put forth a novel proposition that met with favor even in many conservative quarters. He proposed, in brief, a national railroad commission. composed of the chairmen of the various state railroad commissions and with a gentleman appointed by the President from the District of Columbia as its head, with complete power to adjust, without appeal, all questions relating to interstate traffic. ${ }^{2}$ This suggestion was most interesting, perhaps, as pointing the way to the overthrow of old state political prejudices through the growth of vast business interests.

To the appeal of the commission for assistance the legislature responded with an apparent enlargement of its powers. ${ }^{3}$ But when the new commissioners came to apply the provisions of the law in 1882 , they found this purpose thwarted by the inconsistent and incongruous language of the new act. They discovered that their powers and duties were practically the same as those of their predecessors. Whether purposely thus drawn or not, it was evident that the legislature had determined to proceed cautiously in the matter of government supervision and regulation, preferring to let the state endure the evils resulting from im-

' See Railway Age, Oct. 27, 188 r.

3 Report of Railroad Commission, 1882, p. 12.

'Laws, 1881, pp. 68-73. 
proper railroad management rather than to drive away capital by harsh or extreme measures. ${ }^{1}$

The most fruitful source of trouble at this time, as indeed, in the entire South, was the high level of local rates. Dissatisfaction was greatly intensified, moreover, by the steady movement toward consolidation,- - a movement practically unhampered by the state, that had progressed until nearly all the main lines of transportation were under the control of three corporations, chief among them being the Louisville and Nashville. Moreover, they had become powerful enough to compel the navigation companies operating on the Ohio and other rivers to join with them to a great extent in the fixing of rates. ${ }^{2}$

The commission found itself powerless to render material assistance to shippers. Yet it did not think it proper for the legislature to prescribe "cast-iron rates", or to confer such power on the commission, for it feared that such a step would deter capital from coming into the state, when it was perfectly evident that Kentucky was in great need of more and better railroads. It appealed, therefore,- - though in vain,- - to the legislators for the power, merely, to supervise changes in rates and to prescribe a uniform system of accounts. $^{3}$

The greatest burden of complaint on the part of shippers had to do with the charges exacted for the transportation of coal. The extensive coal fields in the eastern and southwestern parts of the state had but recently begun to be developed on a large scale. The commission, upon investigation, found that every road with a mine upon its own line was striving to foster that mine at the expense of mines on

1 Report of Railroad Commission, 1882, pp. 4-5. 10.

Ibid., 1883, pp. 52-55.

Ibid., 1883, pp. 67,77 . 
other lines. Thus, while hauling coal from its own mine at a low through rate, it was charging a high local rate for the transportation of coal coming from the mines of other roads. Investigation also convinced the commissioners that coal ought not to be sold anywhere in Kentucky for more than ten cents a bushel, whereas the average price was actually far above this,- running of ten as high as sixteen cents. ${ }^{1}$

In an informal way they submitted to the companies a proposition to the effect that all charges for the haulage of coal should be at the same rate as the charges for transportation from their own particular mines. They urged that the cheapening of the retail price of coal would bring about such an increased consumption as more than to offset, in revenue, the decrease in the rates charged. ${ }^{2}$

The railroads, however, would have none of this, and politely but firmly refused compliance with the commission's request. All protests of the latter, for more than a decade following, were disregarded; and all recommendations to the legislature for increased powers, or for the placing of restrictions upon the price of this necessary article of commerce were ignored. ${ }^{3}$ In 1896 , for instance, the cry came from all parts of the state that the coal rates were too high, and yet the board found it itself " powerless to remedy the evil":

For some years after the establishment of the commission a vigorous and persistent effort was made at each succeeding session of the legislature, with but one exception, to repeal the commission law. These efforts, supported as they were by a numerous lobby of railroad officials and em-

1 Report of Railroad Commission, 1885. pp. 11-13, 16.

' lbid., 1885, p. 13.

3 16 id., 1886, p. 11; 1887 , p. 22; 1889 , p. 4 ; 1893, p. 49, and 1896 , p. 16.

1 10id., 1806, p. 15. 
ployees, seem to have rested, not upon the notion that the commission's powers were excessive, but rather upon the point that the railroads were private affairs and therefore not subject to legislative control. ${ }^{1}$ Not until a new state constitution was framed and adopted in $189 \mathrm{I}$, in which the supporters of commission control secured the insertion of provisions which made the commissioners constitutional officers, and continued in force the existing laws regarding their powers and duties, was an end put to those attacks. ${ }^{2}$

Still the commission labored on under the greatest difficulties. For one thing, the burden was upon the board of proving the unjustness or unreasonableness of rates or charges-an extremely difficult and somewhat expensive matter. Again, there was no fund provided to meet the expenses of prosecuting violations of the law. As a result, punishments of corporations for extortion and unjust discrimination were few and far between. And in 1896 the commission was deprived of all power whatever to supervise rates by a decision of the Kentucky Court of Appeals. Two years previously, upon a recommendation of the board filed before a county jury, a number of indictments had been returned against the Louisville and Nashville Railroad Company, "charging that corporation with extortion, unjust discrimination, undue preference and the violation of the long and short haul section of the constitution ". From a verdict in favor of the commonwealth the carrier appealed, as a last step, to the Court of Appeals. That court held all portions of the law in question, excepting the long and short haul clause, to be unconstitutional and "void for uncertainty", in that they failed to prescribe a standard of just-

1 Report of Railroad Commission, 1888, p. 4 ; 1891, p. 6.

Kentucky Constitution, I\&gr, sec. ccix.

- Report of Railroad Commission, 1900, p. II. 
ness and reasonableness, by which the railroads might regulate their conduct. ${ }^{1}$

This decision put it squarely up to the legislature to afford relief by appropriate legislation. The commission recommended the enactment of a law that should either declare, in unmistakable terms, what just and reasonable compensation is, or fix reasonable maximum rates of charges. ${ }^{2}$ A bitter fight at once developed. At the session of 1898 a bill was finally pushed through both houses, empowering the commission to make just and reasonable freight rates. It iell under the displeasure of the governor, however, and he vetoed it, assigning as his reason its alleged unconstitutionality. Nothing daunted, the friends of the measure rallied again to its support at the following session of the legislature, and this time-June, 1900-all opposition was bowled over. " Power was conferred upon the commission, either upon complaint or upon its own motion, to prescribe "reasonable and just" freight and passenger rates in place if those which should be found to be extortionate." The wording of the statute, however, left much to be desired in the matter of clearness, with the unfortunate result that misunderstandings soon arose between the board and the railroads as to the interpretation of the law-misunderstandings which have only recently been removed by a decision of the United States Supreme Court.

\section{THE COMMISSION UNDER THE MCCHORD ACT OF 1900}

Before the commission had even undertaken to enforce the provision of the new law, suits werc filed by the leading

' 57 S. W. Rep., p. 508.

'Report of Railroad Commission, 1896, p. 16.

'Senate Journal, 1900, pp. 396, 690.

- Refort of Roilroad Commission, 1900. p. 13. 
carriers in the federal courts, praying for the issuance of injunctions. The issues came before Judge Evans, who rendered his decision in favor of the railroads. ${ }^{1}$ An appeal was at once taken by the commissioners to the United States Supreme Court. Carefully avoiding an expression of opinion as to the constitutionality of the act, that Court unanimously reversed Judge Evans on the ground that the suits had been prematurely brought, since no order prescribing rates had as yet been made by the commission. ${ }^{2}$

The commissioners, whose hands had now been tied for over a year and a half by the injunctions, resolved to proceed cautiously at first, in order to avoid possible litigation. When complete files of the tariffs in force upon each road operating in the state had been finally collected they began an investigation of the numerous complaints that had accumulated since the passage of the new act. ${ }^{3}$

The attention of the board was diverted for a while from this work by a request from Governor Beckham to ascertain the truth or falsity of frequent rumors in the press and elsewhere, to the effect that the consolidation of various competing and parallel railroad lines in the state was being stealthily undertaken by certain outside interests. After a lengthy study of the situation the commission filed a complaint before the Interstate Commerce Commission late in 1902, alleging that J. P. Morgan and Co., at the head of a voting trust in control of the stock of the Southern Railway and in possession of entrances into both Chicago and St. Louis, had obtained control over the stock of the Louisville and Nashville and the Atlantic Coast Line-two competitors of the Southern Railway-and in so doing had acted

'Report of Railroad Commission, 1900, p. I3.

2 McChord z's. L. \& N. R. R. Co., 183 U. S., 502.

3 Report of Railroad Commission, 1902, pp. 10-12. 
contrary to the provisions of the Kentucky constitution. At the hearings before the Interstate Commerce Commission a large number of witnesses, including Mr. Morgan himself, were present and testified. The testimony brought out the fact that many of the parties who were in control of the Northern Securities Company had contemplated the formation of a Southern Securities Company to hold a majority of the stock of the southern railroads. The whole proceeding soon came to an end, however, upon the handing down by the United States Circuit Court of Appeals and, on appeal, by the United States Supreme Court, of decisions in the Northern Securities case, to the effect that such a plan of consolidation could not legally be executed. ${ }^{2}$

It was not until the autumn of 1905 that the commission determined upon a vigorous course of action with reference to a revision of charges. Somewhat earlier, one Guenther had filed a complaint with the board in which he alleged that all charges on intrastate freight moving to and from local points in Kentucky were discriminating and excessive. He prayed the commission, therefore, to revise and adjust all such rates. Subsequently, three lumber companies and also the state of Kentucky petitioned to be made parties complainant to the Guenther proceedings, which petitions were granted. The railroads then appeared before the commission and objected that the complaints against them were not sufficiently definite and specific, in that they specified neither the rates claimed to be exorbitant nor the commodities alleged to be discriminated against. ${ }^{2}$

The commission ruled, nevertheless, that the entire subject of railroad rates in Kentucky was now before it for consideration. In order to pass intelligently upon this dif-

1 Report of Railroad Commission, 1902, pp. 13, 89; 1903, pp. Ia-11.

Ibid., 1909, pp. 317-18. 
ficult matter a number of extended hearings were had, and the railroads were given a full opportunity to justify the rates then in force. In view of the fact that the greater part of the state was traversed and served by five large companies-the Louisville and Nashville, the Illinois Central, the Southern Railway, the Chesapeake and Ohio, and the Cincinnati, New Orleans and Texas Pacific-the commission resolved to confine its investigation mainly to those roads.

In their answer the carriers denied that any of their rates were either unjust or discriminatory. They argued, further, that the various communities and businesses throughout the state had been built up and fostered under the existing adjustment of rates and that "any radical departures from this adjustment would be disastrous, not only to the shippers but to the communities served by the railroads." I It was finally agreed by both sides, however, that four representative months from the year 1905 should be selected, and that the carriers should furnish to the commission all the information obtainable for those months regarding such matters as capitalization, construction, operation, amount of traffic (both interstate and intrastate), income and the like.

As the measure of the cost of doing business, the railroads took the percentage of operating expenses to gross receipts, as had been done in the celebrated Smyth $v$. Ames case by carriers attacking the rates fixed by the Nebraska legislature. In elaborate tables they sought to prove that it was costing them from ten to twenty-five per cent more to conduct the purely intrastate business than the average of all business done within the state, and that "this excess cost or percent should be added to the proportion of oper-

1 Report of Railroad Commission, 1907, p. 63. 
ating expenses to gross receipts for all traftic to indicate the cost to the carrier for the intrastate business." 1 The Louisville and Nashville, for instance, reported that the percentage of its total operating expenses to its total earnings in Kentucky, both interstate and intrastate business included, was 69.16 , and that the cost of conducting its purely intrastate business was greater by twenty per cent. Adding 3.42 per cent as the proportion of its state taxes, it asserted that the cost of carrying its intrastate traffic during 1905 (based on the four representative months) had amounted to the amazing total of $97.5^{8}$ per cent of its gross earnings on such freight. ${ }^{2}$

The commission quickly pointed out the fallacy in these and similar claims. It showed that a factor such as 69.16 did not stand for total cost at all, nor for any part of the cost, but simply represented " the relation between the total cost expressed in dollars and cents and the total receipts expressed in dollars and cents". The cost and the earnings might both be high or both be low, and yet the same relation might exist. "The cost of doing a particular part of the whole traffic may be more than the average cost, and yet the percentage of that cost to high earnings on that particular traffic may be less than the percentage of the whole cost to the gross earnings." " Clearly the cost to the carriers of a given amount of traffic had no "necessary connection with the earnings derived from that traffic", said the commission.

The board then went on to show that the intrastate rates in effect at that time had come down from the past with but very few changes. Little had been done for many years, said the commissioners,

1 Report of Railroad Commission, 1907. pp. 65-66.

Ibid., 1907, p. 66.

stid., 1907. p. 67. 
except to occasionally lower or raise some of them, notwithstanding the fact that the volume of business has very greatly increased, and the receipts of all the railroads have steadily grown, and the remarkable improvement in motive power and equipment enables them to handle the traffic with much less labor and cost proportionate to the volume of business done. ${ }^{1}$

Investigation revealed, further, that the rates charged by the railroads operating north of the Ohio and east of the Mississippi rivers were very much lower than the rates in force throughout Kentucky.

It was but natural, therefore, for the board to come to the conclusion that the majority of the intrastate freight rates were, as contended, extortionate and unreasonable. Schedules of maximum freight rates were accordingly prepared and promulgated in the summer of 1906 and made to apply to the leading railroads of the state. For the purpose of giving effect to this order the Southern Classification was adopted as the official freight classification of Kentucky. ${ }^{2}$

Bills were at once filed in the United States Circuit Court by the Louisville and Nashville, and by three other companies, contending, on certain grounds, that the order was void, and praying for the issuance of injunctions. The Circuit Court, disregarding the important claims that the order was confiscatory and also void for want of power in the commission, decided in the company's favor on the ground that both the act of 1900 and the commission's order were in violation of the Fourteenth Amendment of the United States Constitution. ${ }^{3}$ The commissioners denied the jurisdiction of the Court in the case, and appealed to the United States Supreme Court. That Court, in an opinion handed

${ }^{1}$ Report of Railroad Commission, 1907, p. 62.

'Ibid., 1907, pp. 75-80.

3 so3 Fed. Rep., p. 216. 
down in April, 1909, and once more cautiously avoiding the question as to the constitutionality of the McChord Act of 1900 , affirmed the final decrees of the court below. It held that since the language of the statute did not expressly confer any power upon the board to "enter upon a general investigation of every rate upon every class of commodities carried by all the railroads of the state from and to all points therein, and to make a general tariff of rates throughout the state", the bestowal of such an enormous power could not be assumed by implication. ${ }^{2}$

There was nothing for the commission to do, accordingly, but to bide its time and to await a favorable opportunity for the renewal of its program of rate reduction.

In the meantime, some relief had been extended to the shippers of the state by the commission in the eradication of a long-standing evil. In the early history of the Kentucky board the legislature enacted a "long and short haul " law very similar to the "long and short haul " clause in the Interstate Commerce Commission Act of 1887 , bestowing upon the commissioners, however, the power to relax the severity of this law in case they should deem it expedient to do so. The operation of this law was soon found to be very discriminating against the business interests of the state in favor of the interests of other states and, in particular, of the cities of other states just beyond the Kentucky line. This was due, mainly, to a ruling of the Interstate Commerce Commission, whereby interstate railroads were permitted to make rates into points in Kentucky based on "the lowest combination". Repeated efforts, naturally, wcre made by the shippers of the state to secure relief. In 1899 , for instance, a strong attempt was made, in connection with the struggle over the proposed increase

$$
\text { ' } 213 \text { U. S., p. } 198 .
$$


in the commission's powers, to secure the nullification of the law. It failed; and yet the movement was rewarded with a measure of success, inasmuch as the commission was induced to grant the exemption of a few "common points" from the operation of the law.' "Common points" was a designation for such places in Kentucky as were served by a river and a railroad, or by two or more railroads.

Decisive action was finally taken in 1908 , after a long fight headed by the Louisville Board of Trade. In hearings before the commission during that year, numerous glaring inequalities were brought to light. It was shown, for example, that Louisville shippers, in many instances, were being forced to pay higher freight rates to points within the state than shippers in Cincinnati, St. Louis, Indianapolis, Chicago, Memphis, etc., notwithstanding the fact that the difference in distance in each case was in favor of Louisville. First-class freight was being carried from St. Louis to Robards, near Henderson, Ky., at a rate of fiftytwo cents, and from Cincinnati at a rate of fifty-five cents; whereas Louisville shippers to the same point, though many miles nearer than their competitors in St. Louis and Cincinnati, were compelled to pay fifty-six cents. On the "lowest combination" hasis it was pointed out that the rate from Louisville would be but forty-three cents. "In order to give full relief," it was urged, "it was necessary that every point in the state should, in the making of rates, have the benefit of its proximity to the nearest common point." 2 The traffic manager of the Louisville and Nashville testified that his company would willingly conform its rates to the "lowest combination" basis, if permitted to do so by

${ }^{1}$ Report of Railroad Commission, 1908, p. 38; Louisillle Erening Post, Nov. 24, 1908.

2 Ibid, p. 38 . 
the commission; and he was of the opinion that all the other roads doing business in Kentucky were likewise willing to conform. ${ }^{2}$

The upshot of the investigation was that the commission issued an order, relieving the railroads from the operation of the "long and short haul" clause, "to the extent of permitting them to make rates based on the "lowest combination' in all cases in which such lowest combination would give a lower rate than that which would otherwise apply." : Why the commission, however, did not take this step long before is unfortunately not explained in the pages of its reports.

In 1910 came the opportunity for rate-reduction for which the commissioners were waiting. In March of that year the Louisville and Nashville withdrew some special rates which it had given years before to the owners of distilleries along its lines in Kentucky. Numerous distillery companies complained to the commission that the new rates levied in the place of the old were exorbitant. The board sustained their contention and proceeded to prescribe, as maximum rates, the special rates that had but recently been withdrawn. ${ }^{3}$ The railroad thereupon moved for an injunction, attacking the action of the commission as in violation alike of certain provisions of both the state and federal constitutions. On a showing of irreparable injury, a restraining order was granted by the Circuit Court, but the motion for an injunction was denied. Upon appeal to the United States Supreme Court the commission was sustained, the Court holding that the board had full power, after notice and hearing, to prescribe reasonable maximum intrastate

'Louiszille Ezening Post, Nov. 24, 1908.

Report of Railroud Commission, 1908, p. 39.

slbid., 1913. pp. $463-64$. 
rates in the place of such rates as it might deem extortionate or discriminatory. ${ }^{2}$

The Louisville and Nashville, nothing daunted, then filed an amended and supplementary bill, bringing in as defendants the parties in whose favor reparation had been awarded by the commissioners, and again moved for an injunction. The application was denied by the United States Circuit Court, and the Supreme Court, on appeal, again affirmed the order of the court below. ${ }^{2}$ Thus recently, in January of I9I5, after nearly fifteen years of struggle in the courts, was the true status of the commission finally determined.

In their Report for I9I I the commissioners took occasion to refer to the crudeness and imperfection of the laws concerning state regulation of railroads in Kentucky, and to remind the people and legislators that their state had lagged far behind every other southern state (except West Virginia) in that important matter." For one thing, the statute imposed various important duties upon the carriers, while it failed to provide any penalty for non-performance. For example, no penalty was attached to the departure by a railroad from its published tariffs. In the second place, the commission was still without power to require the railroad companies to form through routes and to make joint rates -a stage which practically all the remaining southern commissions had long since passed through. Again, no power had been conferred upon the board to promulgate demurrage rules, or rules regulating the duty of the carriers to furnish cars to shippers. Further, the railroads had no penalty to fear for failure to provide sufficient accommodations for the transportation of either passengers or freight after the

1231 U. S., p. 320.

${ }^{2} 235$ U. S., pp. 602-10.

- Report of Railroad Commission, 1911, pp. 3-6. 
lapse of a reasonable time from the giving of notice by the commission. Finally, and most important, there were as yet no restrictions upon the power of the roads to increase (or decrease) their rates upon traffic wholly intrastate. There was no requirement - contrary to the practise elsewhere throughout the South-of a notice to the public of an intention to increase rates, - so that shippers had no opportunity to be heard prior to the date of their going into effect, while the commission had no authority either to suspend or prohibit the increase. "A proper regard for the business interests of the state," said the commissioners quite correctly, "demands that the right to make the increase should be determined before it actually takes effect, rather than after it has taken effect."

Nevertheless the commission believed that it would not be the part of wisdom for the state to go as far in the regulation of railroads as most of the southern commonivealths had traveled. It would not do, for instance, to enact a comprehensive law governing every detail of railroad operation and management, such as had recently been passed in New York. "As crude and imperfect ... as our present law is," declared the commissioners, "we believe . . . that we should be content for the present with an amendment of the existing law to the extent that experience has clearly shown it to be defective." 1

The legislation which the commission had in mind was introduced in both the senate and the house; but the railroad and other interests combined to defeat it."

In their report for 1912 the commissioners again recommended the passage of the legislation which they had shortly before proposed. They urged, in general, that power be

1 Report of Railroad Commission, 1911, p. 3

: lbid., 1912, p. 13. 
conferred upon them to put an end to railroad practises detrimental, in their opinion, to the public, and to prescribe rules necessary for the public convenience and not unreasonably burdensome upon the carriers. In particular, they asked for the authority to compel the physical connection of railroads where circumstances and the public convenience: justify it; for the power to investigate the causes of all accidents (and not alone, as limited by the statute, to cases, merely, where death ensued), "with a view of minimizing the injuries to passengers and employees and protecting their lives "; and for the enactment of an anti-pass law. It was altogether likely, as the commission suggested, that the want of such a statute had long played an important, and perhaps a chief, rôle in the prevention of that stricter legislation so ardently desired for years by both commissioners and public-spirited men. It was high time, indeed, that Kentucky should fall in line with its more progressive sister commonwealths. ${ }^{1}$

The most urgent appeal of the commissioners, however, was for legislation that would permit the people of the state to enjoy the full benefit of her many navigable streams. As matters then stood, whenever a waterway route attempted to compete for traffic with a railroad, the railroad simply reduced its rates to such an extent as to force the water carrier sooner or later either to abandon the field or to sell out to its rival. With the competition removed the rates were raised to the former, or possibly an even higher, level. The commission was of the opinion that the best way to stamp out this abuse would be to provide that in case a railroad company should reduce its rates by reason of water competition, those rates were not to be increased unless the railroad could show that transportation conditions had

${ }^{1}$ Report of Railrood Commission, 1912, pp. 13-14. 
meanwhile changed. This was essentially the ruling of the Interstate Commerce Commission. Then, with capital invested in water carriers protected, like that in railroad carriers, by the laws of the state, "the citizens of Kentucky will be privileged to reap the benefit of nature's generosity." Nevertheless, in view of the steady dwindling of river tonnage in Louisiana, despite sympathetic action by the state commission and the prompt and reliable service of the steamboats, it is much to be doubted whether the anticipations of the commissioners were not entirely too lofty.

In their report for 1913 they again drew attention to the many defects in the law, ${ }^{1}$ and in the following year they repeated the recommendations of former reports. ${ }^{2}$ In the effort to remedy conditions, certain legislation was again presented to the assembly. Like its predecessors, however. the legislature of 1914 refused to come to the assistance of the commissioners.

In consequence, the authority enjoyed by the Kentucky commission, by comparison with the power conferred upon the commissions of the other southern states, is almost insignificant. There is probably no state railroad commission in the entire United States with jurisdiction and powers more circumscribed than the railroad commission of the conservative state of Kentucky:

In recent years a movement has been growing in the state, sponsored by men of high station, for the transformation of the board into a public utilities commission. That this movement, in view of the present state of the public mind towards corporations, will be crowned with success in the relatively near future, cannot seriously be questioned.

'Report of Railroad Conmission, 19'3. p. 2.

2 Ibid., 1914. p. 8. 


\section{CHAPTER X}

\section{Alabama \\ I. THE ADVISORY COMMISSION}

As early as 1873 the attention of the legislature was directed in the annual message of the governor to the advisability of creating some officer of state to be charged with the duty of collecting statistical material regarding the various railroads of Alabama. "All departments of the state government," affirmed Governor Lewis,

and more especially the General Assembly, are in need of the statistics which such an officer would obtain for their information and intelligent direction. . . . And these vast miracles of modern invention now involve so much of life and property, and tend to infringe on human rights in so many respectsthat the duty of intelligent legislation can no longer be performed without a full knowledge of all facts necessary to their just and careful supervision.

He recommended, therefore, the enactment of a law creating the office of commissioner of railroads and insurance companies. ${ }^{1}$ But no attention was paid by either house to this suggestion.

The next reference to the railroad question on the part of the executive was made by Governor Cobb in 1880 . "Your sole object," he stated to the legislature,

will be to correct abuses and to prevent extortion and unjust

1 House Journal, 1873, p. 12. 
discriminations by the railroads; and to attain this you should not hesitate to exert all the power vested in the legislature. I am not prepared to assist you with specific recommendations, ... but I will coöperate with you in devising, shaping, and perfecting such action as to your judgment shall appear proper and adequate. ${ }^{1}$

Agreeable to this suggestion, bills were reported in both houses providing for the creation of a board of railroad commissioners. The lower chamber was the first to act. A drastic measure, modeled on the provisions of the Georgia statute of 1879 , was prepared by the committee on commerce and common carriers, and put through without much difficulty. ${ }^{2}$ The senate refused its approval and passed a substitute bill of its own, wherein the authority to prescribe rates and fares was withheld from the commissioners. A conference committee was then appointed to arrange matters. As usual, the conservative opinion prevailed, and the bill, as passed, was essentially the senate's measure."

As with the Georgia commission, the Alabama commissioners were given the power to examine the railroads of the state as often as they should deem proper; to inspect the books and papers of the companies; to issue subpoenas and to examine witnesses: and to prosecute violations of the law.

But the similarities between the two commissions were far outweighed in importance by the differences. First and foremost, the dangerous power to fix and prescribe rates and fares upon its own initiative was withheld, and in its place a novelty in southern practise appeared, comparable only to the right of "homologation" enjoyed at

1 Senate Journal, 1880 , p. 35.

2 House Journal, $1880-8$ i, p. 548.

'Senale Journal, r880-81, pp. 448, 502. 
that time by the French Minister of Public Works, and in a way, also to the powers possessed by the Kansas commission. The carriers were required, upon the organization of the board and as often thereafter as might be deemed necessary, to submit their tariffs of freight and passenger charges for examination. If the commission should find any charge which, in its judgment, was more than just compensation for the service for which it was being made, or which amounted to unjust discrimination against any person or locality, it was promptly to notify the carrier at fault of the proper correction. Further, upon the receipt from shippers of complaints in writing alleging specific instances of extortion or the like, the commission was to determine at a hearing the truth or falsity of the allegation and notify the railroad, if found guilty, of any changes judged advisable. ${ }^{1}$

No authority was given to the commission, it will be noticed, to compel the railroads to put in force the revisions of the tariffs as made by the board, nor was compulsion laid by law upon the carriers even to submit their tariffs for revision. The legislators trusted that the force of public opinion would be all-powerful in the first instance; and as for the second, they resorted to a resourceful expedient that had proved effective elsewhere. The railroads at this time, of course, were subject to constant and expensive litigation under complaints of extortion, discrimination, etc., so that any device that would afford them a proper method of protection was certain to have their favorable consideration. The law provided, therefore, that all railroads submitting their tariffs for revision and acting under these tariffs as approved by the commission were to be relieved from all liability whatsoever (except, naturally, for

${ }^{1}$ Laws, 1880-81, pp. 87-95. 
actual damage) in so far as the approval of the commission was to be prima facic evidence in behalf of the railroad that the tariff was not extortionate.

Theoretically, then, there was little reason why the carriers should submit their tariffs to revision at the hands of the board; but from the practical standpoint, the chances were very greatly in favor of their doing so.

Other features of the law were not so desirable. No provision was made, for example, for the presence on the commission of a man experienced in railroad matters. Indeed, the statute distinctly stated that no person in the employ of railroads or owning stocks or bonds issued by them should be eligible for the position of commissioner. And then the term of office was restricted to a paltry two years, as in the Virginia plan, so that just when the members of the board were beginning to acquire the first rudiments of knowledge in regard to their duties and to be of some value to the state, the expiration of their terms would throw them upon the governor's favor for reappointment. ${ }^{1}$

All in all, however, the provisions of the Alabama law were a vast improvement upon those of the commissioner law of Virginia of 1877 , and they were destined, as models for legislatures in other states, to have a considerable influence upon the whole course of southern experience.

\section{The Work of the Commission}

After organization the commissioners sensibly conferred with the Georgia commission for the purpose, chiefly, of acquainting themselves somewhat with the methods of practise in use by that body. Then they called upon each railroad company to furnish detailed information regarding its management, " appurtenances and equipments". Some 
of the carriers, for the time being, denied their authority to request this information; but in the end all the roads gave way. Then, after an examination of the tariffs, the commission prepared an outline of the charges deemed proper and conferred with officials from each company in regard to these revisions. Finally followed the publication of the tariffs as revised. ${ }^{1}$

In the work of revision the commission pursued a most interesting method of getting at the real valuation of each company. Disregarding entirely the mere cost of construction, on the grounds that most of the roads had been built when the prices of materials were much higher than in I88I, and that they were now in the hands of purchasers or lessees owning or operating them on terms far below, and little concerned with, the cost of construction, they took, as the best test available, their earning capacity. First, the net earnings were ascertained by the deduction from gross earnings of all the expenses of maintenance and operation, together with the payments for taxes. Next, a profit of eight per cent per annum was settled upon as a fair and just return; for this would pay the interest charged and leave two or three per cent for contingencies. Finally, the commission figured out the sum upon which these net earnings were eight per cent and, with a few exceptions, established this as the value of the road. ${ }^{2}$ Assuming, for instance, that the net earnings of a certain carrier were one million dollars, the commission thus settled upon twelve and one-half million dollars as the fair value of the road.

A wave of protest from the railroads greeted the publication of their revised tariffs. The dissent was loudest on the part of those whose passenger fare rates had been re-

'Report of Railroad Commission, 1882, pp. 7-8.

= Ibid., 1882, pp. 13. 16-17. 
duced to a nuaximum of three cents a mile. But protest was in vain, for the commission promptly threatened to bring suit for forfeiture of charter in case of non-compliance with its rulings. The carriers, with much grumbling, then allowed the tariffs, as revised, to go into effect on the date appointed. ${ }^{2}$

The classification in use at that time by most of the Alabama railroads was that of the Southern Railway and Steamship Association. Uniformity in classification was desirable, of course, and so the commission recommended to the other railroads the desirability of adopting the above classification. Those railroads, however, which had their own classifications preferred, in the main, not to discard them, and the consequence, for a good many years to come, was an unfortunate lack of uniformity, with its resulting hardships for both carriers and shippers.

At the session of the legislature in 1883 an important amendment to the railroad law was adopted. It was recognized that the power of the commission in regard to rates was insufficient,-as judged, for example, by the Georgia standards; and it was accordingly made the duty of the commissioners from time to time to "carefully revise all tariffs of charges for transportation made by any person or corporation owning or operating a railroad in this state ", and to "increase or decrease any of the rates, as experience and business operations may show to be just ". From then on, therefore, the Alabama commission may be regarded as more mandatory than advisory in character.

Report of Railroad Commission, 1882, p. 24.

Ibid., 1882, p. 26.

- Acts, 1883, p. $17 \%$. 


\section{THE MANDATORY COMMISSION}

In their report for $188_{3}$ the commissioners declared that the calamities which many persons had prophesied would fall upon the railroads as a result of state supervision had, in reality, not occurred, and that, on the contrary, " railroads have continued to prosper more than ever before", while "the prejudices which have existed against railroads in the popular mind ... have largely disappeared ".' Again, in I888, the commissioners called attention to the large increase in railroad mileage in the state as "conclusive proof that capitalists have confidence in the future of Alabama, and that no apprehension is felt that unfriendly legislation will impair the value of their investments ".

The reports of the commission for more than two decades after its creation are full of references to the agreeableness of their official relations with the railroad companies. ${ }^{3}$ The carriers, with "apparent cheerfulness", seem to have acquiesced generally in the rulings of the commission, "even when they were not fully convinced that reductions were demanded by reason and justice". Nevertheless, during all those years the commission appealed with great earnestness to the legislature for the bestowal of greater and additional powers, ${ }^{4}$ for, in its opinion, there were " very great evils which the present system of state supervision does not reach in some instances, and in other instances does not adequately correct." " "The railroad commission ... needs more power than it now has to make it efficient." ${ }^{\circ}$

'Report of Railroad Commission, 1883, p. 4I.

2 Ibid., 1888, p. 9.

s lbid., 1885, pp. 13, 17-18; 1886, p. 24; 1904, p. 8.

' bid., 1884, p. 35 ; 1902, pp. 5-6.

s Ibid., 1884, p. 37.

'lbid., 1884, p. 38. 
As in the case of other southern commissions, the chief complaint was that the remedy of civil action or indictment was quite inadequate against roads that refused to comply with its rules and orders. It urged, therefore, that power be conferred upon it to proceed by injunction or mandamus. Finally, in 1903, the legislature yielded, and the recommendations of the commissioners were enacted into law.'

On numerous occasions attempts were made in both house and senate to widen the jurisdiction of the conmission, and to place under its supervision and control all the public carriers of the state. ${ }^{2}$ According to the statements of 'Governor Comer in $191 \mathrm{I}$,

the railroads kept a paid attorney in the lobby at the capitol while the legislature was in session, not for the purpose of practising law, but to revise and control all law-making. They also maintained a regular pass-giver whose business it was to environ and control as far as possible with passes and favors those who were attempting to shape the policies and politics of the state.

The opposition was finally carried off its feet in 1907, when the nation-wide agitation of that year swept over Alabama, and the jurisdiction of the commission was so extended by the legislature as to embrace most of the public utility companies of the state.

The same legislature also passed several other laws of a decidedly restrictive nature which, in connection with the enactment enlarging its authority, involved the commission for the following six years in wearisome litigation with a number of the carriers. The measures most offensive to the railroads were those reducing passenger fares from

${ }^{2}$ Report of Railroad Commission. 1903, p. 3.

Ibid., 1907. p. 4.

Senate Journal, 1911, p. 48. 
three cents a mile (a rate that competition among the principal railroads had established early in the history of the commission over most of the state) to two and one-half cents, and reducing the freight rates on one hundred and ten articles of common production and use so as to put them " on the same practical basis as has been for many years the rate on the same articles on the same class of railroads in Georgia and many other states ".

Thereupon the leading roads of the state appeared before Judge Jones of the United States Circuit Court, sitting at Montgomery, and prayed the court to delay by injunction the operation of those statutes. The judge lent a sympathetic ear to the cry of confiscation, and granted injunctions not only against the execution of the two laws above referred to, but also against various other restrictive measures, such, for example, as the act forbidding the transferring of suits at law from state to federal courts.

From these decisions an appeal was forthwith taken to the Circuit Court of Appeals, sitting at New Orleans. That court dissolved the injunction on the ground that a fair trial of the new rates would best prove whether or not they were confiscatory. Meanwhile the majority of the roads operating in the state, headed by the Illinois Central, the Southern Railway, the Seaboard Air Line, and the Atlantic Coast Line, had resolved upon a policy of conciliation, and had settled their contentions with the state by having their cases dismissed, and by putting into effect the rates established by the legislature. ${ }^{2}$ There were several roads, however, including the Louisville and Nashville, and the Central of Georgia, that were bent upon continuing the contest, and they took an appeal from the Circuit Court, accordingly, to

\footnotetext{
'Senate Journal, 1911, p. $5 \mathrm{I}$.

"Ibid., 1911, p. 52.
} 
the Supreme Court of the United States. The decision of that body, in line with former opinions, was to the effect that the state of Alabama is possessed both of the power, through the legislature, of making passenger and freight rates, provided that such rates were not confiscatory, and of the authority of delegating its power to the railroad commission. $^{2}$ Under the decision the contested laws were put into operation on June I, 1909 .

In its report for 1908, the Alabama commission called attention to the fact that, in the case of those railroads that had submitted to the legislative rates, the increase in passenger earnings for 1908 over 1907 had amounted, on an average, to three and one-half per cent, whereas the increase in the case of those roads that were still operating under the old three-cent rate had been but two and one-fifth per cent. This greater increase in the first group of carriers was due primarily, so the commission claimed, to the stimulating effect on travel of the lower tariff."

The new rates had been in force for but little over a month on the refractory roads, however, when those carricrs again appeared before Judge Jones with the contention that the freight and passenger rates laid down by the state were proving confiscatory. Attorneys for the commonwealth interposed an emphatic negative. The judge thereupon appointed several masters to take evidence in the case. and to determine, if possible, the truth or falsity of the railroads' position. The taking of evidence began early in 1910 and continued, off and on, into 1912. While the Louisville and Nashville case was being thrashed out before a Master in Louisville, Ky., Judge Jones ordered the cases of the remaining roads to be taken up at other places, thus necessi. tating an unfortunate division of the state's attorneys. The

'Report of Railroad Commission, 1908, pp. 50, 51. 
judge very probably had no intention of weakening the state's side by thus dividing the suits and compelling the simultaneous hearing of evidence at widely separated places. And yet the attorneys for the state were placed at a great disadvantage thereby, for each one was forced, usually single-handed, to face the formidable array of legal ability which the railroads were able to assemble.

In April, 1912, Judge Jones handed down his decision, holding that the railroads were justified in their contentions. An appeal was at once taken by the state.

The railroad commission then determined, upon its own motion, to put an end to the controversy. In June of the same year it cited the Louisville and Nashville and other roads to appear before it and show cause why the commission itself, through the general powers bestowed upon it by statute, should not fix a reasonable rate for passenger travel in Alabama. After an immense amount of evidence had again been taken, the commission, in February of 1913, issued an order prescribing two and one-half cents per mile as a reasonable passenger rate for all roads still operating in Alabama under the three-cent rate. The Louisville and Nashville then assailed the validity of this order in the Federal District Court at Montgomery, and succeeded in procuring a temporary restraining order. An application for an injunction, however, was denied. Pending an appeal to the United States Supreme Court from the decision denying the injunction, the railroad made application for a continuation of the restraining order. This application, also, was denied, and upon request to Justice Lamar of the Federal Supreme Court at Washington for a supersedeas, the railroad was further rebuffed. The Louisville and Nashville thereupon gave up the struggle, and by August, I9I3, the two and one-half-cent rate was finally in effect upon all the Alabama roads. 


\section{CHAPTER XI}

\section{TENNESSEE}

\section{THE FIRST MANDATORY COMMISSION}

THE first official reference to the evils connected with railway transportation in Tennessee appears to have been made by Governor Brown in his annual message of 1875 to the legislature. Alluding to the widespread and general nature of complaints of discrimination throughout the state, he laid it upon the legislators, as their duty. " to ascertain the extent of the grievances, and provide, if possible, appropriate remedies." In view of the numerous embarrassments surrounding the question he suggested that "the appointment of a select committee, with power to collect the facts, and charged with the duty of reporting a bill, by the light of these facts, might develop a plan that would correct the evils." 1 But neither house took kindly to his suggestion, and even a resolution providing for the appointment of a committee to take into consideration this portion of the message was laid over. ${ }^{2}$

The railroad question would not be downed, however, the more so since the consolidation of both parallel and endto-end lines was going on apace in Tennessee. By 1882 , for example, six railroads rumning into Nashville and originally built as competing lines. had become consolidated into a

Senate Appendix, 1875, pp. 30-31.

'Vashrille Union and American, Jan. 10, 1875. 449] 
single system that held within its grasp well nigh the entire commerce of the central part of the state. ${ }^{1}$ Beginning with the late seventies, the democratic party incorporated each year in its platform declarations in favor of government regulation of railroads, and in 1882 the republican party followed suit. ${ }^{2}$

Early in 1883 Governor Hawkins set the ball rolling with well-chosen words of advice to the legislature, wherein he cautioned, at the same time, against hasty or ill-advised legislation. ${ }^{3}$ Both chambers agreed that under the platforms there was an obligation resting upon them to establish a commission, but they differed radically as to the character of this proposed commission. The senate adopted a bill with extremely moderate provisions; the house, on the contrary, passed a measure that was regarded by the railroads as entirely too rigorous. As usual, conservatism prevailed, and the house accepted with but few changes the moderate bill of the senate. ${ }^{4}$

The law, as finally approved, provided for a railroad commission of three members to be appointed by the governor with the advice and consent of the senate, and to hold office until the first of January, I885. Their successors were to be elected by the voters of the state at the November election in 1884 , and so on every two years thereafter. The powers of the commissioners were, in general, those of the Alabama commission established in $188 \mathrm{I}$, namely, the powers of examination and revision of passenger and freight tariffs, and of general supervision over the railroads."

'Nashrille American, March 28, 1883 .

Ibid., March 19, 1885.

3 Appendix to House and Senate Journals, 1883, p. 13.

- Senate Journal, 1883, p. 607 ; House Journal, 1883, p. 764.

- Lazus of Tenressee, 1883 , ch. cxcix, secs. xi-xxi. 
Immediately upon the organization of the commission, requests were forwarded to the various railroads operating in the state to furnish, for revision, a schedule of their rates of charges for freight and passengers. With but one exception-the Nashville, Chattanooga and St. Louis Railroad-this information was sooner or later provided. Thereupon the commissioners began their work of investigation and revision, and in consultation with prominent railroad officials prepared by the end of the year a basis of freight rates for most of the Tennessee railroads. But when they proceeded in December to revise the tariffs of the Louisville and Nashville and the East Tennessee, Virginia and Georgia Railroads they met with a great deal of opposition, which culminated in February of the following year in the issuance of injunctions from the United States Circuit Court, restraining the commission in its work of revision. As soon as those two injunctions were granted, four other companies applied for and obtained restraining orders. The embarrassing position of the commissioners now became so great that they deemed it inadvisable to proceed longer with that part of their work. Their prestige, in fact, was so shattered that for the remainder of 1884 the commission law was practically a dead letter. ${ }^{2}$

The comparatively small Democratic majority in the state elections of 1884 emboldened the Republicans in the legislature of 1885 to make an issue of the railroad situation in the hope of thereby dividing the Democratic party and of carrying the next election for themselves. Disregarding, therefore, the suggestion of Governor Bate in his annual message that the bill of 1883 be not repealed but simply purged of its defects, ${ }^{2}$ they introduced a number of bills in

'Report of Railroad Commission, 1883. pp. 17-23; ibid., 1884, pp. 25-29.

Appendix to House and Senate Journals, 1885, pp. 15-16. 
both houses looking to the overthrow of the railroad commission. With the assistance of a handful of Democrats who felt that "a law inoperative in every feature, except the single one providing for the payment of salaries ", and "subversive of the public welfare in expensive and fruitless litigation", ought not to be retained on the statute books, ${ }^{1}$ they jammed through a bill in the senate repealing the railroad commission act of $1883 .{ }^{2}$ The question of repeal then came up in the house. The friends of commission regulation first offered, as a substitute, a commission bill exceedingly mild in its provisions. It did not meet the favor of the elements composing the railroad majority, however, and was promptly voted down. Then a still milder bill, aiming chiefly to meet the constitutional objections to the act of 1883 , was dealt with in a similar way. In despair the regulation men finally declared their willingness to accept the repeal of the commission law, provided only that a measure should be enacted affirming the power of the state to regulate as between its citizens and the railroads, and affording some particle of relief. To this end they proposed a measure merely defining extortion and unjust discrimination and imposing a penalty for its violation. This overture, likewise, was rejected. Then the opposition collapsed, and the senate bill was carried through the house by a large majority. ${ }^{3}$

Governor Bate promptly interposed his veto on the ground that the railroad commission had been endorsed by the people in the election of 1884 , and that no matter how objectionable the act of $x 883$ might be in some of its fea-

${ }^{1}$ House Journal, I885, pp. 817-18; Nashville American, April 5, 1885.

${ }^{3}$ Senate Journal, 1885 , p. 334.

Nashville American, 1885, March 28-29, April 4; House Journal, 1885 , p. 666. 
tures it was certainly better than no law at all.' In this position he was undoubtedly correct. Both house and senate, however, proceeded promptly to overrule the governor's veto, and the activities of the ill-fated railroad commission came thus abruptly to an end. ${ }^{2}$

\section{THE SECOND MANDATORY COMMISSION}

For a dozen years Tennessee was without a commission. Nor does there appear to have been any movement during that time for the re-establishment of the first one. Certain it is that the legislative journals are silent about this question. But in 1897 , for some reason, railroad regulation came to the fore again, and of the bills that were considered at the legislative session of that year, one developed into law.

The senate favored a weak commission, while the house held out for a board with mandatory authority; and it held out so stubbornly that the senate finally capitulated." The powers and duties of the new commission were those of the prevailing strong commissions in the United States; the language of the new statute, indeed, was very similar to that of the Mississippi law of $1884^{\circ}$

For the first two years after organization the commissioners were so occupied with the valuation and assessment of the railroad properties of Tennessee for taxation-an extra duty imposed by the law of 1897 -and with litigation over the validity of such assessment that they had no time

'Senate Journal, 1885, pp. 584-91.

'Ibid., p. 591: House Journal, 1885, p. 816.

- Nashrille American, Jan. 14, Feb. 21, March 13 and 25, April 3. May 2, 1897.

- Senate Journal, 1896, pp. 503, 607, 613, 616, 910-12: House Journal. 1897. pp. 239, 607.

- Acts, 1897 , ch. $x$. 
to formulate and put into effect general passenger and freight tariffs. ${ }^{1}$ The utmost that they could do was to secure and file the tariffs of the various companies, together with fiscal reports and other documents useful for future action, and to hear and determine a number of special cases. ${ }^{2}$

In the summer of 1889 the commission finally entered upon a consideration of the carriers' schedules. Conscious of its inexperience in railroad matters it proceeded with great caution and deliberation. The investigation, in fact, lasted off and on for over two years, at the end of which time the tariffs of most of the roads were approved in the form submitted to the board. The commissioners were of the opinion that the charges for transportation in Tennessee, by comparison with the charges in contiguous states, were not too high, and they were especially unwilling to draw the state into expensive litigation through any hasty action of their own. ${ }^{3}$

For nearly a decade following there appears to have been but little friction between the railroads and the commission, although, of course, there were numberless disputes between the carriers and shippers over charges on interstate freight. ${ }^{4}$ The source of greatest concern to the board was the discrimination in passenger charges as the result of the want of an anti-pass law. Disregarding the moral phase of the evil, the commissioners laid stress upon the higher level of charges thus made necessary and the consequent injustice to the public through the gratuitous carriage of so large a portion of Tennessee's population. The standard fare fixed by the competition of the railroads was about

${ }^{1}$ Report of Railroad Commission, 1897-98, pp. 8-9.

Ibid., I $897-98$, p. Io.

"Ibid., 1899-1900, pp. 3-4, 9, 31 ; 1902, p. 28.

4 lbid., 1903-0.4, pp. 4, 10; 1905-06, p. 4 ; 1907-08, p. 3. 
three cents a mile at that time. The commission hesitated to lower this level in the absence of an anti-pass law, and worked unceasingly, therefore, for the abolition of this discriminating practise,-yet without success. ${ }^{2}$

In Tennessee, as in other states of the south, there was considerable agitation in 1907 for a reduction of passenger fares. The commission sought a conference with the trunk lines regarding this matter and secured from three of them - the Southern, the Mobile and Ohio, and the Cincinnati, New Orleans and Texas Pacific-a promise voluntarily to give to the state rates as favorable as other states might secure from them as a result of litigation. Accordingly, when the standard rate on these roads was reduced in adjoining states to two and one-half cents per mile, they kept their word and reduced their Tennessee rates to the same figure. ${ }^{2}$

Encouraged by this action, the commission issued an order early in 1908, applying the two and one-half-cent rate to all the remaining railroads operating in the state. This order seems to have been made, unfortunately, without a proper investigation. At any rate, four important companies - the Louisville and Nashville; the Nashville, Chattanooga and St. Louis; the Yazoo and Mississippi Valley; and the Illinois Central-refused to put this rate into effect. The commission then called a conference. An agreement was there entered into by which both sides agreed to await the result of the decision in the Alabama rate cases, inasmuch as the same questions were involved in both states. In the meantime the roads were to issue coupon tickets in the same manner as such tickets were being issued under the order of the court in Alabama. ${ }^{2}$

'Report of Railroad Commission, I901-02, pp. 39, 46-50.

I Ibid., 1907-08, p. 6. 
The two and one-half-cent rate was found to apply with such severity to the smaller roads as to compel the board, shortly after, to exempt them from that rate. ${ }^{1}$

Not till the spring of 1912 was a decision rendered in the Alabama rate cases, and it proved to be in favor of the railroads. The Alabama commission then promulgated an order of its own, prescribing a two-cent rate, and after a vain effort on the part of the railroads to obtain an injunction from the federal authorities, the order went into effect in the summer of $1913 .^{2}$

The Tennessee commission at once conferred with the companies with which it had come to an understanding five years before. The carriers were inclined at first to stand upon the strict letter of the agreement. But when they were unable to prove to the commission's satisfaction that a two and one-half-cent rate would be so unreasonably low as to amount to confiscation and when they realized that the commission was determined to resort to litigation, if need be, to attain its purpose, they gave way." The Louisville and Nashville, and the Nashville, Chattanooga and St. Louis put the new rate into effect in the spring of I9I4, and the Illinois Central somewhat later."

Since the establishment of the commission in 1897 changes have been made from time to time in the freight classifications and schedules to secure uniformity of rates and to prevent discrimination and overcharges. The commissioners appear to have displayed a rather conciliatory attitude toward the railroads and to have met, on the whole,

${ }^{1}$ Report of Railroad Commission, 1907-08, p. 7.

Ibid., 1913-14, pp. 13-15.

3 Report of Railroad Commission (Tenn.), 1913-14, pp. 15-19.

- The Mobile \& Ohio had meanwhile become a part of the Southern system, and automatically received the two and one-half cent rate. 
with a gratifying appreciation of their efforts. Certain it is that, whatever the reason may be, there has been an unusual absence of friction for nearly two decades between commissioners and railroads in Tennessee. ${ }^{2}$

'Report of Railroad Commission, 1907-08, p. 4; 1909-10, p. 5 ; 191112, p. 4 


\section{CHAPTER XII}

\section{MISSISSIPPI}

Although it is probable that the subject of railroad supervision had been brought up at various times in the legislature before the session of 1884 , yet little progress had been made against the railroad interests until then. But early in that year under the influence, very likely, of the restrictive legislation shortly before enacted in Alabama and South Carolina, a bill passed both houses providing for the regulation of freight and passenger rates by a board of commissioners. ${ }^{1}$ Governor Lowry felt obliged, however, to return it unsigned on account of the presence of several unconstitutional provisions. At the same time he urged the preparation and passage of another bill with the elimination of those defects. ${ }^{2}$ Other bills were accordingly reported, modified so as to meet his objections, and referred to the appropriate committees. A substitute bill was quickly reported back, and, passing both house and senate practically unchanged, it received the governor's signature. ${ }^{3}$ This commission law was couched in language rather similar to that of the Alabama statute of I88I. Provision was made for a board of three commissioners to examine the condition of railroads from time to time, to revise their tariffs," to

1 House Journal, I884, pp. 172, 254.

2 Ibid., pp. 322-27; Annual Cyclopadia, r884, p. 528.

'House Journal, 1884, p. 517; Natchez Democrat, March I, I884.

- The powers of the Mississippi commissioners in this matter were somewhat greater than those of the Alabama commission, for it was 148 
enforce the rules regarding extortion and discrimination. and to make annual reports based upon the returns of the carriers. ${ }^{3}$

No sooner had the commission organized than steps were taken by most of the Mississippi roads to test the constitutionality of the act creating it. Writs of injunction, restraining the board from any interference whatsoever with their business or property, and from the performance of the duties required by the statute, were applied for and secured; some in the state courts, others in the United States Circuit Court for the Southern District of Mississippi. Appeals were at once taken by the commission, in the one case to the Mississippi Supreme Court, in the other to the Supreme Court of the United States. ${ }^{2}$ The state court promptly sustained both the law and the commission, ${ }^{3}$ and in 1886 the Federal court followed suit.

Meanwhile some of the smaller roads had filed their tariffs with the board in accordance with the statute. The commissioners, deeming it inexpedient, if not unjust, to restrain these railroads in their rates while the most important railroads in the state were enjoying an exemption from the operation of the law, pending the decision of the United States Supreme Court, simply decided to put off the work of revision for the time being, and therefore attached their certificate of approval to all tariffs submitted to them."

made their "duty" to revise the carriers' tariffs, the tariffs as revised being binding, unless overthrown in the courts; and charges were to be prescribed for all roads neglecting or refusing to file their tariffs with the commission. See Laws of 1884, ch. xxiii. sec. vi.

'Laws, I884, ch. xxiii.

2 Report of Mississippi Railroad Commission, in Department Reports for $1884-85$, p. 1 .

' Stone r's. Yazoo R. R. Co., 62 Miss., 607 ; also 62 Miss., 646.

- Department Reports for $1884-85$. p. 2. 
Prevented, then, by injunctions, from enforcing the principal features of the railroad supervision law, the commissioners for the first two years did little more than attend to trifling matters of routine.

When the new commissioners, fortified by the decision of the United States Supreme Court upholding the Mississippi law, entered upon their duties in 1886 , they proceeded to more active measures. They were impressed at the outset with the importance of securing a uniform system of classification of freight for all the railroads operating in the state. At their invitation, the general freight agents of these roads convened in Jackson and put their suggestions at the disposal of the board. In the naive language of the report,- " To the extent that they (i.e., the suggestions) conformed to our views they were adopted". But it was found impossible to bring complete order out of the existing chaos on account of the great instability and wide difference of rates prevailing. As a temporary measure, then, railroads with eastern connections were authorized to continue the use of the Southern Railway and Steamship Association classification, while a new classification was prescribed for such roads as were then using the Mississippi Valley Joint classification. ${ }^{1}$

The question as to the revision of rates was equally perplexing. In the charters of the most important roads there were provisions establishing maximum rates to which those roads threatened to appeal in case the commission should undertake to revise their tariffs. The commission, of course, might have countered with a threat of forfeiture of charter. But not wishing to become involved in heavy litigation, as had the first commissioners, they contented themselves for the present with merely seeing to it that the rates

${ }^{3}$ Report of Railroad Commission, 1887, p. 167. 
charged by those companies were not above the maximum fixed by their charters.'

The freight tariffs of several of the other roads were reduced somewhat, for the disproportion between through and local rates in Mississippi at that time, according to the commission, was simply enormous. The aim of those reductions was to put the local rates more nearly in line with the through rates. ${ }^{2}$

Passenger rates, because of excessive competition for years past, were already exceedingly low. In fact, a rate of three cents per mile already prevailed on all of the leading railroads. The commission, therefore, readily approved the passenger tariffs of those companies and made but unimportant changes on the remaining lines. ${ }^{8}$

In 1888 the classification of the Southern Railway and Steamship Association was extended by the commission to all the roads doing business in the state, for the reason that the southern carriers in general were using that classification in connection with their interstate business.

The conservative policy adopted by the commissioners in 1886 has been, in the main, steadily continued since that time, so that relations between the state and the corporations under its supervision have been much more pleasant than in the majority of the southern states. There have been numerous stretches of years during which not a single mandate of the commission has been disobeyed." Reductions from time to time have been made in freight and passenger charges, and changes effected in the classification, but al-

' Report of Railroad Commission, 1887, pp. 165-166.

Ibid., 1887, p. 168.

Ibid., 1887, p. 167.

' lbid., 1888-9, pp. 4-5.

-Ibid., 1891-93, p. 3 ; ibid., 1895-97, p. 4; ibid., 1909-11, p. 6. 
I52 REGULATION OF RAILROADS IN THE SOUTH [462

ways, so the commission claims, with no permanent loss of revenue to the railroads. ${ }^{1}$ As in other states, the greatest difficulties for many years arose from the commission's lack of authority to establish and enforce joint rates. ${ }^{2}$

The Mississippi commission was the first commission in the country to establish reciprocal demurrage rules. The carriers naturally contested this order, but the state Supreme Court sustained the board in this matter, and those rules have been in force ever since.

${ }^{1}$ Report of Railroad Commission, I888-89, pp. 8-9; 1895-97, p. 4; 1899 I9OI, pp. 3-6.

Ibid., 1889-9r, p. 6. 


\section{CHAPTER XIII}

\section{FLORIDA}

\section{THE FIRST MANDATORY COMMISSION}

AlThough bills for the creation of a railroad commission had been introduced in the legislature from time to time before 1887 , the first decisive legislative struggle in regard to this question took place in that year as a result of the declarations of Governor Perry in his annual message. "Experience in most of the states," he stated, "has demonstrated that the commissioner system is a safe one for all interests, when the commissioners are able and incorruptible, conservative and just men, though given ample powers and bound by rules having no little flexibility." 2 According to the press of that day, " a careful consideration of the subject in all its bearings" had now convinced the people that the establishment of an effective railroad commission was a matter of vital importance, and that it could no longer be postponed. ${ }^{2}$ In response, then, both to the governor's suggestion and to the demand of the people, bills were speedily introduced in both chambers of the legislature, providing for the regulation of the Florida railroads and for the creation of a board of commissioners. A joint select committee, to which the majority of these bills was referred, reported out a bill modeled after the mandatory law established in Georgia in 1879 . The friends of this

'House Journal, 188\%, p. 22.

- Florida Times-Union, May 27, 1887. 463] 
measure, though proving to be in an overwhelming majority in both house and senate, nevertheless refrained from pushing it in undue haste, in order that a reasonable length of time might be secured to its opponents for investigation and discussion. In the end, after certain irregularities had been eradicated and a new bill correcting them had been framed, the commission regulation idea was adopted by the legislature, and the law went into effect early in the summer of I $887^{1}$.

This Florida law, which was copied almost entirely from the Georgia law of eight years before, and which granted to three commissioners the authority to make "reasonable and just" rates of freight and passenger tariffs and regulations for the prevention of unjust discrimination and the like, had one very curious feature. A board of revisers was established, consisting of the comptroller, secretary of state, commissioner of agriculture, attorney-general, and treasurer, to hear any protests that the railroads might make and to "change, abrogate, revise or remodel ", at their discretion, the action of the railroad commissioners. ${ }^{2}$ This was an unwise provision, of course, for the members of this board were already so taken up with their own official business as to have no time left for the proper consideration of whatever matters might come before them in their new capacity.

The choice of the governor fell upon three men who, though wanting in practical experience in railroad management, were nevertheless gentlemen of the highest qualities, and in no sense aspirants for political preferment. To Judge MclWhorter, indeed, had been awarded the highest judicial honors in the gift of his state, and no man stood

${ }^{1}$ Senate Journal, 1887, pp. 497, 623; House Journal, 1887, pp. 224-5, 492, $712,720,920$.

Laws of 1887 , ch. mmmdccxlvi, secs. i-xvii. 
higher in the confidence of the people. His wealth and position were such as to preclude the inducement of the salary connected with the office. Judge Vann and Mr. Himes were likewise well-known throughout Florida and highly esteemed for their sound common sense.

After organization, the commission issued a notice to the railroads of the state and to the public generally of a meeting to be held in September at Tallahassee for the purpose of fixing rates for the transportation of freight and passengers, and for the making of the necessary regulations prescribed by the statute. The railroads were ordered to furnish, in addition to their freight and passenger tariffs, copies of their latest annual reports and detailed statements of their net earnings and operating expenses since January Ist, 1887. At this meeting the railroad managers declared with one voice that it was the plain duty of the commission to legalize and adopt the tariffs and schedules then in force, and they insisted that their charges were perfectly just and reasonable. The commissioners soon found upon investigation, however, that the rates charged, even where conditions were not greatly dissimilar, showed wide differences, and, further, that the ratios of increase in freight charges, according to distance, were most irregular among the various railroads. ${ }^{2}$

The commission was persuaded that the passenger rates were, on the whole, too high, and accordingly, the standard passenger tariff was fixed at three cents a mile, and made to apply to a majority of the railroad mileage in the state."

The work of drawing up a satisfactory schedule of

- Florida Times-Union, Aug. 4, 1887.

Report of Railroad Commission, 1887-88, pp. 4, 14.

Ibid., 1887-88, pp. 14-15.

- Ibid., pp. 12, 20. 
charges for the transportation of freight proved much more difficult. There was, first of all, the question of classification, since the adoption of a uniform classification was absolutely necessary for the proper and intelligent making and prescribing of freight rates and schedules. Most of the roads were found to be using the Southern Railway and Steamship Association classification of April I, I887, and after examination this classification was in the main adopted. ${ }^{1}$ Then there was the still more difficult question as to what were, anyway, reasonable charges for the transportation of articles of freight. The commissioners were not long in discovering, however, that the average earning capacity of the Florida railroads was remarkably low, because of the facts that the total traffic was as yet comparatively small on account of the sparseness of the population, and that wherever the tonnage was greatest it was largely competitive between the railroads and the boats plying the St. Johns river. The commission therefore contented itself with righting some of the irregularities and with wiping out the most grievous of the prevailing discriminations. ${ }^{2}$ The standard freight tariff was completed and published in October.

Protests were speedily presented to the commission by most of the railroads, and thence to the board of revisers; but the board sustained the commission on all the important points. The roads might then have appealed to the courts for relief. A majority of them, however, gracefully announced their decision to comply with the regulations of the law, and thus victory rested with the commissioners. ${ }^{3}$

The remainder of the life of this commission was com-

${ }^{1}$ Report of Railroad Commission, 1887-88, p. 7.

2 Ibid., 1887-I888, pp. 20-21.

Ibid., I887-88, ए. 24. 
paratively peaceful. The railroads were dealt with in a fair and able manner that rendered discord impossible. When the commissioners, for example, discovered in 1889 from the reports of the railroad companies that the three-cent passenger rate on the trunk lines was proving unremunerative, they promptly raised it to four cents. ${ }^{2}$

Right in the midst of its greatest usefulness the life of the commission was suddenly cut short. Judge McWhorter unfortunately resigned early in 1891 , and to fill the vacancy the governor appointed a gentleman who, in the opinion of the "Times-Union", was "especially distasteful to a large majority of the people. When it became almost conclusive that they must have him on the commission or have no commission at all, they cried aloud for the latter." At any rate a bill calling for the repeal of the act of 1887 was rushed through the legislature, and in the summer of 1891 there came to an end one of the most intelligent railroad commissions that had yet come into existence in the United States."

\section{THE SECOND MANDATORY COMMISSION}

For six years Florida remained without a board of commissioners. Then, all of a sudden, a demand for its reestablishment swept over both houses of the legislature, and bills were rapidly pushed through, first in the senate and then in the house. ${ }^{3}$ The committee in the lower chamber, to which the senate bill was referred, recommended its passage, and it was accordingly taken up as a substitute for the house measure and quickly passed.

This law of 1897 was virtually but a reenactment of the statute of ten years before. The chief difference had to do

1 Report of Railroad Commission, 1888-89, p. 13.

- Florida Times-Union, May 19 and June 6, .1891; Laws of Forida, 1891, pp. 109-10.

Ibid., April 25 and 29, 1897. 
with the commissioners themselves. They were now to be elected by the people, instead of appointed by the governor, ${ }^{1}$ and the provision was inserted that one should be a lawyer, another a railroad man of experience, and the third engaged in agricultural pursuits. The board of revisers feature was dropped, the carriers being given the right of appeal to the courts. Finally, to the commission was now given the important power of prescribing joint rates. ${ }^{2}$

The law as thus passed was undoubtedly of a very drastic nature, and many were the fears of the press and of railroad journals for the future welfare of the state. The Railway Age, for instance, was very severe in its condemnation, declaring that "the state of Florida has served notice on the world that it desires no more money invested in railroad building. ... We can cheerfully promise that she shall have none." 3 At the outset, however, the advantage rested with the commission, for the first members of the board were of a conservative disposition, and were held in the highest respect by all the parties at interest."

The first few months after organization were devoted to a study of the rates and fares and classifications in use upon the various railroads operating in Florida. The commission wisely determined to go slowly at first. The Southern Classification at that time in use upon those roads was adopted as the official classification, to be modified, of course, from time to time, by the published exceptions of the board. ${ }^{5}$ In the schedule of freight rates promulgated, only a few changes in the rates then in force were made, the

1 Pending the general election of 1898 the first commissioners were to be appointed by the governor.

2 Laws, I897, pp. 82-94.

3 Railroad Age, May 4, 1897.

- Florida Times-Union, May 20, 1897.

- Report of Railroad Contmission, Ig00-oI, p. 13. 
main reductions applying to the rates on vegetables, oranges and lemons. Two important innovations, however, were introduced. The straight mileage basis was adopted " as being the fairest manner of computing charges for the transportation of freight ", and the roads were required to discontinue the practise of charging the sums of local rates, in favor of a charge of one joint rate, thereby effecting a considerable saving to shippers. The passenger rates were regarded as comparatively reasonable and just, and they were therefore disturbed in but a few particulars. Although the rate in force upon the trunk lines was four cents a mile, there were certain privileges extended by the railroads, such as the issue of mileage books at two and one-half cents per mile.-that reduced this charge rather markedly. Both railroads and commissions agreed that passenger rates should continue, virtually, as then effective."

Early in 1898 the mileage books were withdrawn by the carriers. Regarding this as a breach of faith and as an unjust increase in rates, the commission reduced the fare on the trunk lines from four cents to three cents per mile. Many of the roads paid no attention to this order and continued to apply their old rates." Upon the advice of the attorney-general to the effect that certain defects existed in the law of 1897 which would make it inadvisable to enforce this order through the courts, the board contented itself with requesting, through the press, all persons overcharged to file their claims for such overcharges. All such claims filed with the commission were subsequently recovered."

When the legislature of 1899 convened, a special committee was appointed, both to draft the amendments requested by the board and to clothe it with the added judicial

1 Report of Railroad Commission, 1897-98, pp. 5, 10, 12.

I Ibid., I898-99, p. 7.

'Ibid., 1898-99. pp. 8, 31.

"Ibid.. 1899-1900, pp. 10-12. 
powers conferred by the amendment to the Florida constitution ratified in 1898 . These provisions were enacted into law during the session, and greatly strengthened the commission (as was soon proved) by more clearly defining its scope and powers. ${ }^{1}$

Immediately after this action by the legislature the commissioners ordered two of the offending railroads to put on sale limited round-trip tickets at a rate of three cents per mile. Upon their refusal to do so writs of mandamus were issued, to which the companies filed petitions for the removal of the proceedings to the federal court. The circuit judge denied these petitions. The companies, on various grounds, then moved to quash the writs. ${ }^{2}$

Meanwhile a case as to the commission's judicial powers had arisen and had gone by appeal to the Supreme Court of the state. On January 8, 1900, the decision of that court was handed down, expressly affirming the validity of the act of 1899 and sustaining the authority of the commission to enforce.its orders by mandamus. The defendant companies then withdrew their motions to quash, and agreed not only to comply with the commission's order, but to put on sale mileage books at a three-cent rate, and to pay all the claims for overcharges then filed. Shortly afterwards the remaining important Florida railroads were required. also, to issue round-trip tickets and mileage books at a threecent rate. ${ }^{3}$ Thus was the authority of the board finally established, as contemplated by the laws of 1897 and 1899 .

The necessity of a fixed and stable freight classification for the state was brought home by the action of the Florida roads late in 1899 . Upon the issue of Southern Classifica-

1 Report of Railroad Commission, 1899-1900, p. 3; Laws, 1899, ch. mmmmdcc.

2 Report of Railroad Commission, 1899-1900, pp. 13-14.

Ibid., 1899-1900, p. 15; ibid., 1900-01, p. 6. 
tion No. 26 they promptly withdrew the classification approved by the commission two years before and proceeded to apply the rates of the new one. Examination having revealed to the commissioners a large increase in rates in No. 26 over No. 25, they promptly declared the old classification to be still in force, and summoned the carriers before them. The latter sought to excuse themselves by alleging that they were under the impression that the board had agreed, in 1897 , to adopt not only Southern Classification No. 25, but also all subsequent and superseding classifications. Convinced more than ever, by this argument, of the desirability of a fixed classification, the commission spent the following six months in a careful study of the whole matter, including a consideration of the railroad's objection to each item, and promulgated its official classification in the spring of $190 \mathrm{I}$-its most important and valuable work since its organization. ${ }^{3}$

For a couple of years affairs ran along rather smoothly. Then in 1903 trouble developed with one of the important carriers. The Louisville and Nashville Railroad was ordered to reduce the maximum passenger fare on one of its divisions from four to three cents a mile. The road refused, alleging that it was actually conducting its Florida business at a loss, and upon this ground secured an injunction from the United States Circuit Court. ${ }^{2}$ The commission had no way of impeaching the elaborate and complicated statement prepared by the railroad, for there was no appropriation sufficient to cover the expensive task of investigating the books and papers of this large corporation. All the more impressed with the necessity for a thorough knowledge of the accounts of the railroad companies of the

' Report of Railroad Commission, rg00-01, pp. 13-14, 16.

'Ibid., 1904-05, p. 30; ibid., 1905-06, p. 9; ibid., 1908-09, p. 14 
state, the commissioners redoubled their efforts to obtain an extra appropriation from the legislature. Not until the session of 1907 were they successful, when an appropriation of $\$ 10,000$ annually was granted them. ${ }^{1}$

The commission was now prepared to combat properly the injunction obtained by the Louisville and Nashville Railroad four years previously. Early in I908 the company was ordered to produce all the books and papers relating to its Florida business since 1897 at its office in Pensacola for investigation and examination. The road at first refused, but after having been threatened with mandamus proceedings, it gave way and granted the board complete access to its books and papers at Pensacola, Louisville, and elsewhere. After this investigation and the taking of testimony had been practically completed, and a very favorable showing in support of the reasonableness of the order of I903 had been made, the Louisville and Nashville deemed it time to yield its ground. A proposition was accordingly made to the commissioners to the effect that the company would put the three-cent rate into operation at once if they would assume their part of the cost of litigation up to date. This offer was accepted, and the injunction of over five years' standing was thereupon dissolved. ${ }^{2}$

The work of auditing the accounts of the Florida carriers is proceeding slowly, hampered as it is by want of special appropriations. The reports of the auditors, ever becoming more comprehensive, will form in time a permanent basis for dealing with the railroads, enabling the commission to avoid litigation in the future, to a great extent, through exact knowledge of their ability to surmount reductions in charges. Only too often at present are the

1 Report of Railroad Commission, 1908-09, p. 13.

2 Ibid., 1911-12, p. 21. 
commissioners, like those of other southern states, obliged to act in the dark from mere inability to get at the necessary information.

Like South Carolina, Florida was almost entirely untouched by the tide of litigation that swept over most of the South from 1907 on in connection with the dispute over passenger fares. Amicable arrangements were effected through conferences whereby the leading roads, headed by the Atlantic Coast Line and the Seaboard Air Line, voluntarily reduced their rates from three to two and three-fourths cents a mile on their main lines and placed mileage books on sale at two cents a mile. ${ }^{1}$ These rates are still in effect.

Freight rates in Florida are probably higher, on the average, than those in any other southern state. But there are important considerations to be kept in mind. The density of traffic per mile of road, for instance, is much less than in any of the neighboring states; and then Florida is a "terminal" state, in the sense that interstate shipments have either their origin or destination within the state (disregarding the slight amount of Cuban traffic). There is thus comparatively little through traffic upon which the roads may depend, and so the charges for local business are correspondingly higher. ${ }^{2}$

With the notable exception of the Florida East Coast Railway, relations between the railroads and the commissioners for the past five years have been very harmonious. Most matters in dispute are readily settled by correspondence or by informal conferences. In the few cases where formal action has been necessary the orders of the commission have been quite generally obeyed without the necessity of a resort to the courts or to legislation.'

'Report of Railroad Commission, 1908-09, pp. q-10.
Ibid., 1914-15, pp. 24-25.
Ibid.. 1914-15. p. 32. 


\section{CHAPTER XIV}

\section{North Carolina}

\section{THE FIGHT FOR A COMMISSION}

At the time when the granger agitation was having, as one of its results, the establishment of railroad commissions in different parts of the United States it was inevitable that the attention of the North Carolina legislators should be directed to the question of government regulation of railways through state commissions. The first bill looking toward the establishment of a commission appears to have been introduced by $\mathrm{Mr}$. Dortch of the senate late in February, 1879. ${ }^{1}$ The senate committee on internal improvements, to which the bill was referred, did not approve, however, of the mandatory character of its provisions and reported back a substitute measure of its own, quite harmless in its nature. A warm discussion followed, at the end of which the substitute bill passed the third reading by a narrow margin. ${ }^{2}$ The house then considered the bill in some detail, and had not the congested condition of the calendar prevented its coming to a third reading it might very easily have become a law. ${ }^{3}$ Thus ended the first important conflict in the legislature.

At the next session another railroad commission bill

1 Senate Journal, 1879, p. 49 r.

Ibid., p. 605.

House Journal, I879, p. 805.

164 
was introduced, and again in the semate, but it died in committee. $^{3}$

iVith the session of 1883 the struggle was renewed. Govcrnor Jarvis, in his message to the legislature, referred very tactfully to former attempts in the state to adjust the conflict between the railroad companies and the people, and gave it as his opinion that the wisest thing to do would be to create a railroad commissioner endowed with advisory and supervisory powers. ${ }^{2}$ The response was gratifying. Three bills were shortly introduced in the senate, and one bill somewhat later in the house. The three senate bills, on the recommendation of the judiciary committee, were referred by the senate to a joint select committee. The outcome of their deliberation was a substitute bill which met with so little favor from the senators as to lead to its speedy withdrawal from discussion." Then the house bill, which had progressed by easy stages to a successful third reading, came up for debate in the senate and was there so plastered with amendments that the two houses were unable to come to any agreement."

Two years later Governor Jarvis again called the attention of the legislature to the advisability of creating some sort of officer to be " charged with the duty of investigating all complaints and reporting them to the General Assembly": Bills were accordingly introduced, but the committee reports were unfavorable, and there the matter rested."

1 Senate Journal, 1881, p. 520.

Legislative Documents, 1883, p. 10.

- Senate Journal, 1883, pp. 92, 254, 401.

- House Journal, 1883, p. 843.

- Legislative Documents, 1885, p. 18.

- Senate Journal, 1885, pp. 221, 229. 
Further attempts were made in the session of 1887 to secure the establishment of a commission, and again they came to naught. ${ }^{1}$ Mr. Ewart, vigorous champion for many years of the commission idea, introduced the remarkable proposal to submit the question of a railroad commission to the voters of the state, but it died, like so many previous proposals, in committee. ${ }^{2}$

The campaign for a railroad commission opened in 1889 with a volley of recommendations from Governor Scales to the legislature. Appropriate legislation for the securing of reasonable rates, for the prevention of rebates, discriminations and pooling, and for the insuring of publicity of all rates was strongly counseled. Then he added: "I would also recommend a commission of three wise, patriotic, and unprejudiced men, with salaries sufficient to render them independent, and enable them to give their whole time to the work." Further, since in his opinion it would be " exceedingly difficult so to frame a bill as to meet every case, without unduly interfering with, if not crippling, the railroads", he advised that " power be given to the commission to consider and adjust all questions of freight and fares, as well as all other controverted questions which may arise between the different railroads themselves, or between the railroads and the citizens ". 3 In response to this appeal no less than five bills were introduced, four of them in the house. The railroad interests, however, were now thoroughly aroused, and although a bill for the regulation of railroads in North Carolina succeeded in passing the house, they were powerful enough to prevent its consideration in the senate. ${ }^{4}$

${ }_{1}$ Senate Journal, 1887, p. 57 I ; House Journal, 1887, pp. 308, 370.

2 Ibid., 1887, p. 345.

- Public Documents, I889, pp. 19-20.

- Senate Journal, I889, p. 542; House Journal, 1889, pp. 420, 541 . 
In his annual message two years later Governor Fowler repeated the recommendations of his predecessor, saying that the time had now come when some step should be taken. "Every state in the Union, except ten," he remarked, "has appointed commissioners and enacted laws to regulate the carrying trade of the railroads in the borders of the different states." 1 As before, numerous bills were introduced, one of which even looked to the supervision of steamboat, canal, express and telegraph companies in addition to railroads. This bill found special favor with the select committee on a railroad commission, and its main ideas were incorporated in a substitute bill reported in the senate. During the course of the discussion it was soon realized that the tide had turned and that North Carolina was finally to have some sort of commission to deal with the railroad question. Upon the passage of its third reading ${ }^{2}$ the house took it up, and sent it back with amendments. Then followed the deliberations of a conference committee, in which differences were patched up, and the fruit of which was a measure acceptable to both houses, providing for the first commission yet to be created in the South with authority over corporations other than railroads. $^{8}$

The statute followed the Georgia law of 1879 in general outline. But there were several important differences, not all of them to be regarded as improvements. The commissioners, instead of being appointed by the governor, were to be elected by the general assembly; and no one having any interest in a railroad was to be eligible for the position. In addition to fixing reasonable and just

'Public Documenis, 1891, pp. 34-35.

Senaie Journal, 1891, pp. 132, 270, 317.

- Senate Journal, 1891, pp. 321, 376, 548, 797, 813; House Journal, p. 726. 
rates and regulations, the board was further to prescribe joint through rates-thus determining at the outset a question that was proving of more and more difficulty in neighboring states. The commission's schedules, however, were made only prima facie evidence of reasonableness, so that the companies were to have the right of appeal from its decisions first to the superior courts and thence to the state supreme court. All laws were repealed by which the railroads were permitted to charge rates other than those that might be prescribed by the commissioners. Finally, it was made their duty to investigate complaints regarding interstate, as well as intrastate, rates of freight, and to bring them to the attention of the Interstate Commerce Commission for consideration before that body. ${ }^{1}$

\section{THE RAILROAD COMMISSION}

The choice of the legislature fell upon three men of excellent reputation. Major Wilson was a gentleman of large experience in railroad matters; Mr. Mason, a farmer and lawyer of ability; and Mr. Beddingfield, a former member of the legislature and active in the work of the Farmers' Alliance. $^{2}$

Previous to organization, Chairman Wilson paid a visit to the Georgia commissioners, making a study of their rules and procedure and of the workings of the law in that state, inasmuch as the laws of the two states were very similar in many respects. Upon his return the board made a careful study of the rates and classifications prevailing in North Carolina. A standard classification for the whole state was presently promulgated, and there followed reductions in freight charges for all roads that were making actual ex-

1 Laws of N. C., I89I, ch. xxx.

'Raleigh News and Observer, March 5, 1891. 
penses. The commissioners were able to announce within a few months that the standard freight rates put into effect by them were as low as, and in many cases lower than, the rates in any other southern state. ${ }^{1}$

Passenger rates were likewise reduced and the standard tariff was fixed at three and one-fourth cents a mile, applying to a great part of the mileage in the state. ${ }^{2}$

The commission appears to have gone about its work very tactfully, for the carriers did not take a single appeal from its rulings. In fact, relations between the board and the railroads were, for a number of years following, very harmonious, all complaints being adjusted to the satisfaction of both complainants and corporations. ${ }^{3}$ The only conflict in the history of the commission came in 1898 as the result of an order reducing passenger rates, first class, on the Wilmington and Welden Railroad from three and one-fourth to two and one-half cents a mile. The board had had a general reduction in passenger rates on the various railroads under consideration for a long time, and it determined, at length, to introduce the reduction first of all upon the above line, as being the most able to stand it. The railroad naturally appealed against this somewhat premature action. The case was finally settled in the federal courts in favor of the commission.

In 1898 an ugly row developed in consequence of the action of Governor Russell in suspending two of the commissioners-Chairman $W$ ilson and a relative of the same name-from office. The governor instituted proceedings in a letter to the chairman in which he made certain allegations as to Major Wilson's connection with the Southern

1 Report of Railroad Commission, 1891, pp. 3-4, 50.

I Ibid., 1891, p. 37.

2 Ibid., p. 3.

-Ibid., 1898, p. 4. 
Railway, and required him to show cause why he should not be removed from his position. In his answer the chairman denied both the allegations and the authority of the governor to suspend him. Governor Russell, however, was convinced after investigation that Major Wilson had disqualified himself, and he therefore suspended him, appointing Mr. Caldwell in his place. This order being disregarded, Mr. Caldwell brought an action to obtain the office. Mr. Wilson set up two defenses in his answer: first, that, even conceding the power of the governor to remove him, he had attempted to exercise it in an unlawful manner, in that he had denied the defendant the fair hearing to which he was entitled by law; and second, that "the part of the railroad commission act of 189 I authorizing such suspension was unconstitutional, inasmuch as it interfered with the independent tenure of a judicial officer, and deprived him of his property in said office without due process of law", thus violating the fourteenth amendment to the United States Constitution. These contentions were nevertheless disallowed by the Superior Court. Appeal was then taken to the state Supreme Court, which held that the railroad commission was not a judicial, but rather an administrative body, and that the court had no authority to review the exercise of the power of suspension when used in an orderly manner. Thus unfortunately there were lost to the commission the services of one of the most distinguished and reputable men in North Carolina. ${ }^{1}$

\section{THE CORPORATION COMMISSION}

At the session of the legislature in 1899 a bill was favorably acted upon which transformed the railroad commission into the first corporation commission created in the United

${ }^{1}$ Report of Railroad Commission, 1897, pp. xxxv-xxxvi. 
States. The powers and duties of the old commission were transferred virtually unchanged to the new board, but its jurisdiction was vastly extended to cover every sort of company or corporation engaged in the carrying of freight or passengers in North Carolina, as well as telephone companies, public and private banks, loan and trust companies, and building and loan associations. ${ }^{2}$

The three gentlemen selected as the first commissioners were all of a high order of capacity: Mr. McNeill, an able and well-informed lawyer; Mr. Beddingfield, who had served for six years on the railroad commission; and $\mathbf{M r}$. Rogers, a former collector of internal revenue and a business man of ability. ${ }^{2}$

For nearly a decade after the enactment of the law of 1899 the course of the corporation commission proved comparatively smooth. Very few of its orders were disobeyed and in but one suit was its position not sustained."

Freight classification No. 25 of the Southern Tariff Association, adopted in 1898 by the old commission, was continued in force by the new board." The most important work was the application, in 1902, of the standard passenger fare rate of three and one-fourth cents, first-class, to almost every road in the state not yet operating under that rate. $^{3}$ North Carolina was at that time the only state in the Union requiring the furnishing, by the railroads, of both first and second-class service for passengers. The commissioners believed from the outset that a lower rate could be maintained with one class of service than with two

'Laws, 1899 , ch. clxiv.

1 Raleigh News and Observer, March 5, 1899.

- Report of Corporation Commission, 1903, pp. 3-4; 1907. p. 6.

- Ibid., 1900, p. 4.

- Report of Corporation Commission, p. 3. 
classes, and they embodied this view from time to time in their annual reports. In 1905 Governor Aycock referred this recommendation to the legislature, ${ }^{1}$ but nothing came of the bills that were introduced because of the failure of the legislators to agree upon a rate for the one class service. ${ }^{2}$

In his message to the legislature in 1907 Governor Glenn proposed a flat rate of two and one-half cents per mile for passenger travel (the corporation commission having favored a reduction to three cents only ${ }^{3}$ ) and the issue of mileage books by the railroads at two cents a mile. ${ }^{4}$ The two houses could not agree over this recommendation, and a conference committee was appointed. The report of the committee favored the exceedingly low rate of two and one-fourth cents per mile. It was nevertheless ratified, and the new rate was ordered to go into effect on July Ist. $^{5}$

Governor Glenn then endeavored to induce the railroads to give the new rate a fair trial, arguing that the probable increase in travel resulting from the low rate might well make it remunerative. Some of the carriers accepted this proposal. ${ }^{\circ}$ Others, however, rejected it and, headed by the Southern Railway, applied for, and obtained injunctions from a United States Circuit Court forbidding the corporation commission and the state attorney-general from putting the law into effect.

The first of July came on, and these roads continued to sell tickets at the old rate of three and one-fourth cents. Governor Glenn, determined to uphold the law and to make

1 Public Documents, 1905, p. 5.

2 Report of Corporation Commission, 1906, p. I1.

3 Ibid., I904, p. 8.

- Public Documents, 1907, pp. 10-11.

- Laws, 1907, ch. ccxvi.

- Public Documents, 1909, p. 4. 
these roads recognize that the laws of the state were to be obeyed until declared unconstitutional by a competent court, addressed a letter to each of the state judges in which he requested them to charge the grand juries to bring in indictments against the offending carriers for their open defiance of the law.

A number of railroad agents were thereupon indicted, convicted and sentenced. Then the United States Circuit Court which had granted the injunctions came to their rescue, and by the writ of habeas corpus discharged them from the custody of the state's officers. ${ }^{2}$ The state at once appealed to the Eleventh Amendment of the Federal Constitution, contending that it could not be sued in a United States Court without its consent and that it never had consented to be thus sued in the matter. ${ }^{2}$ Never before had "so sharp a conflict between the state and the United States courts been presented". The governor was resolved upon enforcing the law, even though it took "every dollar in the treasury and put arms in the hands of every available man in the state". Fortunately, cool heads prevailed upon both sides. An agreement was entered into by which the railroads were to obey the new rate law, pending the determination of its constitutionality in the courts." But the financial crisis in New York that soon followed made a speedy adjustment of the situation imperative.

The governor again interfered and proposed, in brief, that the intrastate rate be raised to two and one-half cents a mile, on the condition that the railroads lower their interstate rate of three cents a mile to two and one-half cents; that mileage books be issued at two cents a mile; and that

1 Public Documents, 1909. pp. 4-5; Biennial Message, 1909. pp. 6-7.

- South Atlantic Quarterly, Bound Volume, 1907, p. 346.

- Public Documents, 1909, p. 5. 
the corporation commission be given the power, after the rate had been in operation a reasonable length of time, to prescribe such changes-subject, of course, to appeal-as would make it reasonable and just. This compromise was accepted, substantially, by the roads, and was ratified by the legislature in extra session. ${ }^{1}$

\section{THE VIRGINIA-NORTH CAROLINA CITIES CONTROVERSY}

For the past seven years or more the main attention of the corporation commission has been devoted to an endeavor to adjust the complicated situation that has existed for several decades as a result of disputes between Virginia cities, on the one hand, and North Carolina cities, on the other. The history of this controversy will be dealt with elsewhere at some length. In this connection the barest outline must suffice.

Shortly after 1873 the Chesapeake and Ohio, stretching westward from Newport News, Va.-just opposite Norfolk-by way of Richmond and Clifton Forge, reached the Ohio river at Cincinnati. In the determination to secure a portion of the western business then moving over northern railroads to the Atlantic seaboard, it offered to carry through freight to Richmond and Norfolk at a rate as low as that for which such freight was being carried from the west over other railroads to Baltimore. From then on, the Baltimore rate became, in the main, the basis for the Richmond and Norfolk rates. And when the Chesapeake and Ohio acquired, in I886, a line of railway leading from Clifton Forge to Richmond by way of Lynchburg-a junction point of three important railroads-it was compelled to give this latter city a through rate as low as the Richmond and Norfolk rate.

When the Norfolk and Western Railway came into the

'Public Docwments, 1909, p. 6; Biennial Message, 1909. 1. 7. 
field and began to compete for the western traffic it was forced, naturally, to adopt the through rates of the Chesapeake and Ohio, for had it sought to charge higher rates it would have secured little, if any, of the tonnage moving east. In 1887 , in conformity with the provisions of the long and short haul clause of the Interstate Commerce act. both of these roads so corrected their schedules of freight charges as to give to all intermediate points on their main lines rates no higher than the through rates in force between Cincinnati and Norfolk.' Later on the Southern Railway, and to a lesser extent, the Seaboard and the Atlantic Coast Line began to compete with the Chesapeake and Ohio and the Norfolk and Western for the east-bound traffic, and they simply met at Lynchburg, Richmond, Norfolk and elsewhere in Virginia, the through rates in force. To offset their low rates to Virginia cities, the three southern roads mentioned above maintained, and at times even increased. their interstate rates to North Carolina points, water competition there being of little or no moment. Freight was accordingly hauled across North Carolina northward to Virginia cities for a less amount than to North Carolina cities; and a like disproportion obtained, in many cases, in the rates on freight originating in North Carolina. As a consequence the jobbers and wholesale merchants in Virginia were enabled to undersell those in North Carolina and to build up the commerce of their state at the expense of their less favored neighbors. ${ }^{2}$

The dissatisfaction in North Carolina resulted, from time to time, in vigorous protests to the Interstate Commerce Commission. In 1899 , for instance, the Wilmington Chamber of Commerce and, a few years later, the Charlotte

Interstate Commerce Commission Reports, vol. viii. p. 422.

- Public Documents, 1909, p. 10. 
Board of Trade brought proceedings before that body. While the discriminations alleged were clearly established, the Commission yet declared itself powerless to afford the proper relief because of the dissimilarity of conditions in the two states. ${ }^{1}$

In 1908 the North Carolina commission decided to take a hand in the matter, authorized by law as it had been recently to bring proceedings before the Interstate Commerce Commission for the correction of discriminations in interstate rates. Investigations having substantiated the truth of numerous complaints, it was decided to bring a test suit as a basis upon which, if successful, other suits of a more comprehensive nature could be founded. Proceedings were accordingly instituted at Washington against the Norfolk and Western for discriminations in favor of Roanoke and Lynchburg, Va., as opposed to Durham and WinstonSalem, N. C.-all four cities being on its own line. The testimony showed, for example, that the above road was exacting a charge of twenty-nine cents per hundred pounds for the transport of grain from Cincinnati to Durham in comparison with a charge of but thirteen cents to Roanoke and other Virginia cities, with an almost negligible difference as to distance. Other discriminations equally glaring were brought to light. ${ }^{2}$

The litigation terminated in favor of the corporation commission, though the reductions made were much less than had been hoped for, and the order was affirmed, on appeal, by the United States Commerce Court. ${ }^{3}$ A precedent having now been established, three more suits were filed, late in 1912, with the Interstate Commerce Commis-

1 Report of Corporation Commission, 1908, pp. 5-6.

2 lbid., 1908, pp. 6-7.

3 Ibid., I910, p. 7 ; 1912, pp. 3-4. 
sion, complaining of rates from the north and east as well as from the west. Shortly afterwards, however, the chairman of the corporation commission, persuaded of the desirability of securing an adjustment by informal conferences between the carriers and representatives of the state rather than by litigation, suggested the propriety of such a course to some of the railroad officials. The roads endorsed the idea, and the result was an extended series of negotiations between the commission and the governor, on the one side, and railroad presidents and traffic managers, on the other. Progress was slow but sure. In the end the railroads yielded on most of the points brought up by the commission, and an agreement was entered into by which comprehensive reductions, applying to all of the United States except the territory east and northeast of Pennsylvania, were made in the rates then in force. ${ }^{1}$ All parts of North Carolina were not equally benefited, it is true, for the railroads positively refused to make reductions to certain points, like Wilmington, on the ground that the rates to those places, whether from water competition or otherwise, were already exceptionally low. The suits filed in Washington against the carriers were of course withdrawn.

This adjustment was submitted to the North Carolina legislature at a special session, was there approved, was sustained upon attack before the Interstate Commerce Commission, and went into effect on June $23.1914 .^{2}$ Considering the magnitude of the whole matter and the quickness and inexpensiveness with which it was settled, this achievement may fairly be ranked ahead of any undertaking whatsoever that up to this time has been carried out by any one of the southern commissions.

1 Report of Corporation Commission, 1912, p. 4: 19:3. pp. 5-7. 35. $38,39$.

2 Ibid., 1913, p. 38: 1014, p. 4. 
In the autumn of I9I4 the controversy was re-opened before the Interstate Commerce Commission on behalf of certain Virginia cities; but it is too early, at this writing, to prophesy the outcome. The final argument is to take place before the Commission at Washington on December I7, I9I5.

At the same special session of the legislature where the corporation commission's adjustment was agreed to, an act, patterned after a recent Minnesota statute, was passed providing for the creation of a special commission to investigate the reasonableness of the intrastate freight rates in force in North Carolina, and to prescribe such changes therein as might seem desirable. Judge Justice, father of the author of this law, was named by the governor as chairman. ${ }^{2}$

Hearings and sessions were held during the winter, spring and summer of I9I4 and the testimony of the principal carriers, of boards of trade, of industrial associations, and of individuals was taken in great detail. Then, in accordance with further provisions of the act of I9I3 authorizing its appointment, the special commission completely revised the intrastate freight rates of the eight railway systems of North Carolina of more than seventy-five miles each in length, and adopted the Southern Classification as the official classification of the state. ${ }^{2}$ The shorter lines are so numerous and their freight rates so divergent, that the legislature had deemed it best to continue control over their freight rates in the corporation commission.

The rates and classification fixed by the special commission went into effect in October, $1914 .^{3}$ A storm of protest

${ }^{1}$ Public Laws, 1913, Extra Session, ch. xx.

${ }^{2}$ Report of Corporation Commission, 1914, p. 66.

3 Ibid., 1914, p. 4. 
at once arose from the carriers, large and small. The principal roads promptly filed tariffs discontinuing many of their intrastate commodity rates (which the corporation commission, however, refused to allow to go into effect),${ }^{1}$ while the shorter lines soon discovered that the rigidity of the long and short haul clause of the act was depriving them of a large part of the state traffic formerly handled by them. The disturbances were so serious that the corporation commission deemed it inopportune to set about the prescribing of standard rate scales for these railroads, and is therefore awaiting the determination of the legislature before taking further action in this important matter. ${ }^{2}$

'Railroad Age Gazetie, Oct. 23, 1914.

' Report of Corporation Commission, 1914, p. 4 


\section{CHAPTER XV}

\section{LOUISIANA}

ThE railroad commission of Louisiana came into existence through provisions in the state constitution of 1898 . Jurisdiction was conferred over railroad, sleeping-car, express, telegraph and telephone companies, and over steamboats and other water craft. The customary duty was laid upon the commissioners (to be elected by the people, each for a term of six years) of adopting, changing, or prescribing reasonable and just rates, and of preventing unjust discrimination and extortion. ${ }^{1}$

At the time when this commission was created there were very few commissions in the United States with jurisdiction over water craft. The question of water competition, however, was probably more important in Louisiana than in any other state of the Union, from the fact that no other commonwealth is traversed by a greater mileage of navigable streams. ${ }^{2}$ There is scarcely a railroad but that is paralleled for at least a portion of its length by streams of more or less depth. Before the organization of the commission, boats plying upon these waters had " no fixed tariff of rates, charging each shipper what pleased them. and paying no attention to distance, classification or value." The inevitable consequence was wholesale cutting of rates, first by the railroads and then by the steamers, leading fre-

1 Louisiana Constitution, I 898 , arts. cclxxxiii-lxxxix.

- Report of Railroad Commission, I899, p. 29. 180 
quently to disastrous and demoralizing rate wars. To make good, as far as possible, the losses suffered by the railroads, interior points not blessed with water competition had to pay abnormally high rates. ${ }^{3}$

To put an end to this state of affairs was the first endeavor of the commissioners. First of all, the steamers were required to file their tariffs and rate books with the commission. Then these tariffs were gone over and revised, and the rule was established that from these new tariffs no changes were to be made without the consent of the board. With all watercraft under the protection of the commissioners, it was hoped that the steamboat traffic would prove as profitable as in years before. ${ }^{2}$

Even, however, with stable rates and the absence of any serious competition between the steamers themselves, the steamers were not able to compete on even terms with the railroads. Year by year, in spite of increases in rates by the commission and of appeals to merchants and business men in general, the river tonnage has dwindled. And there is no indication of any improvement in the immediate future. Such service as is still rendered appears on the whole to be prompt and reliable, but there is comparatively little demand for it. $^{3}$

In proportion, almost, as the steamboat traffic has decreased, has the gasoline-boat trade developed. Great numbers of these boats are now operating on the smaller bayous and rivers, and in regularity and frequency of service they are becoming formidable competitors of the larger boats and even of the railroads." It is not too much to expect

${ }^{2}$ Report of Railroad Commission, 1899, pp. 29-30: 1900, p. 12.

2 Ibid., 1899, p. 30 ; 1900, p. 12; 1903. p. 15.

3 Ibid., 1904, p. 19: 1907, p. 20 ; 1908, p. 31; 1910, p. 15; 1914, p. 29.

- Ibid., 1908, p. 32. 
that these gasoline boats may eventually become the greatest single factor in securing voluntary and permanent reductions in rates from the railroad companies.

The work of regulation, as far as rail lines was concerned, proceeded somewhat slowly at first. For those roads operating east of the Mississippi river, Southern Classification No. 25 was prescribed, and as for those west of that river the Western Classification already in use on many of the lines was extended to all. ${ }^{1}$ No general reduction in freight rates was attempted, and such reductions as were made applied chiefly to the carriage of staple commodities such as rice, cotton, sugar-cane and fuel oil. ${ }^{2}$ With the lapse of time, however, reductions became more and more numerous, with special reference to the charges on such hauls as were unaffected by river competition. ${ }^{\mathbf{3}}$ The report of the commission for as late a year as 1913 , for instance, states that "vast numbers of freight rates have been reduced and only in extreme cases have advances in these rates been countenanced." " Regarding passenger fares, the reports of the commission have been strangely silent.

No railroad commission in the South seems to have been involved in so much litigation as the Louisiana board. From the very year of its existence the railroads have contested almost every order of importance that it has issued." As late as 1913 the commissioners report that " the practice among corporations under the commission's control of contesting orders of the commission by filing suits to set them

${ }^{1}$ Report of Railroad Commission, 1900, pp. 14-15; 1903, pp. 25-26.

2 Ibid., 1899, p. 37 ; 1901, pp. 14-16; 1902, p. 21.

s Ibid., 1906, pp. I0-11.

4 Ibid., 1913, p. 22.

s Ibid., 1899, p. 37 ; 1902, p. 16; 1905, p. 18; 1910, pp. 17-18. 
aside, in state and federal courts, has grown alarmingly." I Under the law it is a very easy matter for a carrier to file a suit of this nature. It merely has to set forth in a petition that the order of which it is complaining is unreasonable, in its opinion, and to ask that it be set aside. Not even an affidavit in support of the allegations is necessary."

The commission has endeavored very seriously to root out this practise, or at least to make it as difficult as possible for the carriers to pursue this course. For example, by a constitutional amendment adopted in 1908, corporations under the commission's jurisdiction are subjected to a penalty of from ten dollars to fifty dollars a day, accruing from the date when the order becomes effective, if, after a resort to the courts to test an order of the commission, such order is there pronounced legal and valid. ${ }^{3}$ Again, a period of limitation-three months from the making of the order-has been fixed within which suits to set aside or modify the commission's orders must be brought. Further, one of the assistant attorney-generals of the state has been assigned since I910 to act as the special counsel of the commission. This official has greatly assisted in clearing the dockets of suits which were filed during the early years of the commission's organization and which had never reached a final determination, and he has made it possible to enforce a speedy trial of most of the cases that now arise. ${ }^{3}$ Finally, a law of the very greatest importance has been recently enacted, which has already rendered val-

1 Report of Railroad Commission, 1913, p. 23.

3 Jbid., 1909, p. 12.

3 Ibid., 1907, p. 6.

4 Ibid., 1908, p. 7.

s Ibid.. 1910, p. 8. 
uable assistance to the commission. ${ }^{1}$ Before the passage of this act the railroad corporations were generally accustomed, as in many other states, to withhold important evidence in their cases before the commission and then, in case of a contest, to present those new facts to the court. Under the new law, however, "corporations are compelled to develop their cases fully before the commission ". For if additional evidence is introduced in court the judge is "required to refer the entire record back to the commission", so that in the end the court is enabled to pass upon exactly the same facts as have been before the commission. ${ }^{2}$

The work of the commissioners, as a consequence, appears to be increasingly efficient. The handicaps of former years having been removed, the commission is moving forward more and more energetically along the way that it has mapped out.

${ }^{1}$ Acts, 1914, no. cxxxii.

${ }^{2}$ Report of Railroad Commission, 1914, pp. 27-28. 


\section{CHAPTER XVI}

\section{WEST VIRGINIA}

As early as 1881 the forces for and against a railroad commission lined up in the West Virginia legislature. "Corporations," said Governor Mathews in his annual message, "should be confined to the exercise of their legitimate powers; they should ... abstain from oppressing any class of their patrons by unjust exactions." " A bill in the senate, sponsored by Mr. Wm. M. O. Dawson (a lifelong advocate of the commission idea and a later governor of the state), and providing for the establishment of a commission, was killed in committee. A bill in the house, prescribing maximum rates and prohibiting extortion, managed to pass that body: but the senate disposed of it by refusing to order it to a third reading. ${ }^{2}$

Interest among the legislators then languished for a good many years. In 1887, for example, Governor Wilson devoted a good part of his message to what he termed the " unreasonable, unjust and ruinous discrimination against our people, in freight and passenger charges, by the trunk line railroads passing through the state", and earnestly urged the creation of a commission "with such authority as may be necessary for the application and execution of the law ".s Yet this recommendation went absolutely unregarded.

Senate Journal, 1881, p. 19.

' Ibid., 1881, pp. 191, 208-11; Housc Journal, 1881, p. 284

' lbid., 1887, pp. 28-32. 4951 
The question was reopened in 1903 by Governor White in his message of that year. Referring to the fact that competition had entirely ceased among the three great trunk lines traversing the state-viz., the Baltimore and Ohio, the Chesapeake and Ohio, and the Norfolk and Westernand that the laws then on the statute books prohibiting unreasonable charges and unjust discrimination were virtually a dead letter, he gave it as his opinion that there was no way out other than the introduction of public regulation. Even a single commissioner, he stated, with power only to investigate and report would be productive of great good, for "publicity itself is a good regulator"." This time there was a feeble response from the house, but the bill was smothered in committee. ${ }^{2}$

Two years later Governor White again called the attention of the legislature to this subject. No other matter had more persistently engaged his attention during the previous four years, he declared, through " appeals from mining, manufacturing and general commercial interests and ... newspaper publications than that of railroad discriminations and the need of legislation which would secure to all shippers equal privileges in the use of these public highways". He reaffirmed, accordingly, all that he had suggested two years before. ${ }^{3}$ And once more a bill creating the office of Commissioner of Railroads and called into being at the governor's suggestion, died in committee.

In 1907 Governor Dawson took up the cudgels in defense of the commission idea.

"There cannot be any doubt," he said, "about the necessity of the creation of a commission to supervise the operation of

'Senate Journal, 1903, pp. 92-97.

'House Journal, 1903, p. 312.

'Biennial Message, 1905, pp. 8r-84. 
railroads. . . We need a commission ... clothed with power after such investigation and hearing as is proper to be given to provide the remedy, including the fixing of maximum rates."

He favored, in fact, a corporation commission, with power to supervise and regulate all the public-service corporations of the state. ${ }^{3}$ Again the governor's advice fell on deaf ears, although the legislature redeemed itself partly in his estimation by the passage of a two-cent passenger fare law. ${ }^{2}$

"For more than thirty years," said Governor Dawson in his message of 1909, "there has been a struggle in this state for protection to the people and business interests from the unjust discriminations and other injustices practised by the railroads. So far in that contest the people have been defeated." . . . "How long," he asked, "will the legislature keep the people of the state in this sort of servility?" s

A public service commission bill was soon after reported in the house. The house committee on railroads, to which it was referred, held a public hearing at which both Governor Dawson and Governor-elect Glasscock appeared, and pleaded for the passage of the bill. At any rate the bill got safely through the house. But in the senate it was referred to the judiciary committee (rather than to the committee on railroads, which was believed to be friendly to it), and there it lingered till the close of the session. Governor Dawson favored the calling of an extra session for the consideration of a public-service commission bill. The senators thereupon held a caucus and decided there to advise the governor against an extra session. For some unknown

'House Journal, 1907, pp. 43-50.

2Ibid., 1907, pp. 66I, 686; Senale Journal, p. 151.

Biennial Message, 1909, pp. 63-64. 
reason he yielded to their advice, and so the bill received no further consideration during that year. ${ }^{1}$

At the session of the legislature in I9I I a public utilities commission bill was introduced at the request of the state board of trade, but it was killed, likewise, in committee. ${ }^{2}$

Not until I9I3 did the struggle of over three decades for commission regulation result in victory. With the Republicans in control of the legislature and pledged by their state platform to the creation of a commission, a public-service commission bill was pushed through both houses at the very close of the session. As modified by the amendments decided upon by the conference committee from house and senate, it was modeled very much after the New York law of $1907 .^{3}$

The jurisdiction of the commission extends to all the public-service corporations of West Virginia. The original board consisted of commissioners appointed by the governor, with the consent of the senate, for two, four, six and eight years respectively. Their successors were to be appointed for terms of eight years each. Not more than two members might belong to the same political party. The concurring judgment of three out of the four was to be deemed the action of the commission.

Ample powers of service and rate control are conferred, but the commission has unfortunately no jurisdiction over the financial operations of public-utility corporations. An interesting provision declares that for the first ten years after the completion of a railroad or plant used in the public service, its charges may not be reduced by the commission below such a point as will prevent annual net earnings of

'Wheeling Intelligencer, Feb. 12, 24 and 27, 1909.

Ibid., Feb. 13-14, 1911.

Ibid., Feb. 10 and 22, 1913. 
at least eight per cent. Appeals from the commission's orders go direct to the highest court of the state and wisely have precedence over most other matters. ${ }^{2}$

In 1915, by amendments to the public-service commission law, the number of commissioners was reduced to three, their salaries were lowered to $\$ 6,000$ each, and the powers and duties of the commission were slightly enlarged.

1 West Virginia Code, 1913, secs. dexxxvi-delvi.

2 Acts, 1913. ch. ix, as amended by Acts of 1915. 


\section{CHAPTER XVII}

\section{Summary of the Present Commission Laws "}

\section{Jurisdiction}

Wrth the exception of Kentucky, the jurisdiction of whose commission extends to steam railroads only, all of the southern commissions have jurisdiction over at least the following companies, viz: steam railroad, car, sleeping-car, car-service, terminal, express, telegraph and telephone companies. ${ }^{2}$ The commissions of all the states except Kentucky and Tennessee have jurisdiction, also, over street and electric railway companies; those of all states except Kentucky, Mississippi and South Carolina, over steamboat and other water craft companies; those of Louisiana, Virginia and West Virginia, over pipe line companies; those of Georgia, North Carolina, South Carolina, Virginia, and West Virginia, over gas, electric light and power companies; those of Louisiana, North Carolina, South Carolina, Virginia and West Virginia, over water and water supply companies; and, finally, those of Virginia and West Virginia, over

${ }^{1}$ The material in this chapter is based upon, first, an admirable publication of the National Civic Federation, entitled Commission Regulation of Public Utilities, and second, the answers received from the various state commissions in response to queries which were sent to the chairmen of all the southern commissions.

'In Alabama, in the case of street and electric railroad companies and also of telegraph and telephone companies, the jurisdiction of the commission is restricted to those only that are operating in more than one city or town. 
turnpike and other internal improvement companies. Jurisdiction, then, is most inclusive in Virginia and West Virginia.

\section{Organization}

Creation. The state commissions, as they exist at present, were established in the following order: 1879 , the Georgia Railroad Commission; 1880, the Kentucky Railroad Commission; 1881 , the Alabama Railroad Commission ; 1882 , the South Carolina Railroad Commission ; 1884, the Mississippi Railroad Commission; 1897, the Florida and Tennessee Railroad Commissions; 1898 , the Louisiana Railroad Commission; 1899, the North Carolina Corporation Commission; 1902, the Virginia Corporation Commission; and 1913, the West Virginia Public Service Commission.

Composition. With the exception of Georgia (which has five commissioners) each board comprises three commissioners, one of whom is selected as chairman (in Alabama termed president), usually by the commission itself.

Manner of Selection. In all but two states-Virginia and West Virginia-the commissioners are elected by the people at the general elections. From the outset the elective system has been by far the favorite method of choice. The most important changes from the appointive to the elective system have been those of Kentucky in $189 x$, Florida in 1897 , and Georgia in 1907.

Term of Office. The term in Alabama, Florida, Kentucky and Mississippi is four years; in the remaining states, six years. There has been a marked tendency in the past two decades toward the longer term. West Virginia, in her law of 1913 (amended in 1915) went so far as to provide for terms of eight years. 
Salary. The range is from $\$ 1,900$ in South Carolina; $\$ 2,000$ in Mississippi and Tennessee; $\$ 2,500$ in Florida and Georgia (the chairman receives $\$ 4,000$ ); $\$ 3,000$ in Alabama (the chairman receives $\$ 3,500$ ), Kentucky (the chairman receives $\$ 3,600)$ and Louisiana; $\$ 3,500$, in North Carolina; and $\$ 4,000$ in Virginia, to $\$ 6,000$ in West Virginia.

Disqualification for Membership. In none of the states may commissioners have an interest (be it direct or indirect) in any corporation or public utility over which the commission has jurisdiction. They are forbidden to accept gifts, gratuities or favors for themselves or friends from the companies under their jurisdiction. Five states -Alabama, Georgia, Kentucky, Tennessee and West Virginia-forbid their commissioners to hold any other political office or to engage in another business. A couple of states provide that one commissioner each is to be chosen from the farmers, lawyers and business men of the state respectively.

Privileges. Alabama, Kentucky, Mississippi, North Carolina, South Carolina, Tennessee and Virginia provide for the free transportation of the commissioners and their employees within the state while in performance of their duties.

Assistants. All the commissions are provided with a secretary or clerk, and the majority of them enjoy the services of one or more rate experts. To some of the boards-notably those of Florida, Georgia and Louisiana -a special attorney is attached, in order that whatever litigation these commissions may be involved in may be the more expeditiously disposed of. The Florida commission is assisted, also, by an inspector-a very necessary and useful official. The other southern states would do well to create similar offices. 
Removal of Members. In about half the states this is done by the governor; in the other half, by the legislature. The causes of removal, as elsewhere, are, in general, inefficiency, neglect of duty, and misconduct or malfeasance in office.

Vacancies are filled, either temporarily, or permanently, by the governor of the state,-in a couple of states, with the advice and consent of the senate.

\section{Duties}

Duties of Supervision. There are comparatively few provisions of law relating to these duties, for the reason chiefly that the legislatures have very often confused duties with powers, and have accordingly provided for many of the commissioners' functions under the head of powers instead, more properly, of that of duties. Regarding such technical matters as construction, maintenance and operation, the requirements in all the states are that the commissions must inspect from time to time the condition, equipment and facilities of each railroad with reference to the safety and convenience of the public. Over half the states require the investigation of accidents and recommendations in regard thereto. In all states it is the duty of the commission to notify the railroads of violations of the law that come to its attention. In a few of the states the commissions are positively required to inspect the books, accounts and papers of the railroads, to investigate the reasonableness of interstate rates so far as their respective states are concerned and to appeal to the Interstate Commerce Commission for relief when it is deemed advisable, to publish schedules of the rates prescribed and to probe for violations of the law regarding extortion and discrimination.

Duties as to Reports. It is the duty of each commis- 
sion to make an annual ${ }^{2}$ report to the governor, ${ }^{2}$ the details of which are specified in a few of the commission laws, and to recommend such revision of the railroad or corporation law as it may deem desirable.

\section{Powers}

Powers Relating to Construction, Maintenance and operation. These, in brief, are powers over roadways, relating to repairs to tracks, bridges, etc.; over crossings, such as the power to separate highway from railroad grades; over stations, such as the power to order the erection or maintenance of suitable depot facilities; and over trains; relating to the equipment, running, and character of service. Every commission is endowed with at least a few of these powers, and the tendency for over a decade has been in the direction of conferring more and more powers of this nature upon the various commissions.

Powers Relating to the Conditions of Business Administration. As regards proceedings, all the commissions have authority to hear complaints and try cases, to inspect books, records and memoranda, to issue subpoenas and to compel the officers, agents and employees of railroads, as well as shippers, to testify under oath.

About half the commissions may regulate the accounting practises of, and prescribe systems of accounts for the companies under their jurisdiction.

Power is conferred upon all the commissions to prescribe, in the main, the details and form of the annual reports which must be rendered by the corporations subject to them.

Under the head of business management there are

'Biennial in Mississippi.

'In Mississippi and South Carolina reports are made to the legislature. 
provisions of the most diverse nature. In Georgia and Virginia, companies must apply to the commission for authority to issue stocks, bonds or other evidences of indebtedness; and in Georgia the amount, purpose and use must be approved by it before issue can be made. In nearly all the states contracts between railroads must first be submitted for the approval of the commission. In every state except Kentucky the commission may prescribe rules and penalties covering the prompt receipt, carriage and delivery of freight; the furnishing of cars to shippers; and storage and demurrage charges.

The powers relative to rates are, of course, the most important of all powers. (a) The general tendency in the South has been toward a wide extension of the ratemaking powers. With the exception of Kentucky, it is now the duty, as well as the privilege, of every commission to make for each railroad operating in the state a schedule of reasonable and just rates, and to revise the same from time to time. This power extends to both freight and passenger rates, as well as to car charges and numerous other charges. The Kentucky commission has power to revise only, either upon complaint or upon its own motion. (b) In 1890 there were but two commissions with power to make joint rates for connecting railroads, and to apportion them between the participating carriers, namely, Georgia and Mississippi. South Carolina fell into line in 1892 and Florida, in 1897. Since then, all of the remaining states, except Kentucky, have conferred this important authority upon their commissions. (c) Every commission has the authority to make regulations for the prevention of extortion and unjust discrimination.

V. The Method of Procedure before the Commissions

In all the states, during the investigation, preparation 
and hearing of cases, the commissions are not bound by the rigorous technical rules of pleading and evidence, and "may exercise such discretion as will facilitate their efforts to understand and learn all the facts bearing upon the right and justice of the matters before them." Briefly, the method of procedure is as follows :

As soon as complaint, either oral or in writing, is made to the commission, an informal statement of the facts, together with the name or title of both plaintiff and defendant, is filed in duplicate by the secretary of the commission. The complaint is then placed on the docket. One copy is mailed to the defendant, with a notice to answer within a certain number of days, and the other becomes a part of the record in the case. The answer, when received, is also filed in duplicate, and one copy is mailed to the plaintiff, the other being placed in the record of the case. If the defendant concedes the demands of the complaint or if he offers to compromise, the matter is referred to the plaintiff, and if the latter accepts the settlement the case is at once closed. Otherwise the case is set for a hearing at a session of the commission convenient to both sides. At the trial legal formalities are, as far as possible, dispensed with. The parties may appear either in person or by attorney. Witnesses may be examined by either side and are further cross-examined by the commissioners. The arguments are then made and the case is submitted. Often decisions are rendered immediately upon the conclusion of the trial. But where questions of great importance are involved the decision is witheld until the whole matter has been carefully considered. The decision, in either event, is embodied in a written order, copies of which are mailed to the plaintiff and defendant. ${ }^{x}$

\footnotetext{
${ }^{1}$ Adapted from Report of Louisiana Railroad Commission, 1899, p. 35 .
} 


\section{CHAPTER XVIII}

\section{Survey of the Present Commission Situation IN THE SOUTH"}

\section{Selection of the Commissioners}

Political considerations still play too great a part in the choice of commissioners. Such considerations are sure to be of undue influence whenever the members of commissions are dependent for their offices upon the caprice of the voters, as they are at present in all the states of the South except Virginia and West Virginia.

The election of railroad commissioners on the State ticket has brought the railroads into politics in a most objectionable way, embittering the relations of railroads and people to the detriment of the interests for which the commission is created, and giving rise to charges of bribery and corruption of a most serious character."

Experience would seem to indicate that the fittest men are secured when the commissioners are appointed by

'This chapter is based upon the answers received in response to queries which were sent to the state commissioners of the South. The compilation of statutes published by the National Civic Federation under the heading, Commission Regulation of Public Utilities (1912), has proved of great service. For many valuable suggestions I am indebted to the excellent survey of public utility commissions in the United States, in Applied History, Vol. I. State Historical Society of Iowa, 1912.

"Dixon, "Recent Railroad Commission Legislation," in Polifical Science Qwarterly, December, 1905. 
the governor. The most capable commissioners in the early history of commission development in the South were those of the first Georgia commissions, while the efficient commissioners of the past decade have undoubtedly been those of Virginia, and in both instances the members of the commissions were selected by the state executives. At the present time, moreover, the membership of a large majority of the strongest commissions (both railroad and public service) of the other portions of the United states is composed of men who owe their positions to the discriminating choice of governors. To name but a few, the commissions of California, Connecticut, Maryland, Massachusetts, New Jersey, New York, Ohio, Pennsylvania, Washington and Wisconsin are appointive. Yet in but two southern states out of eleven are the commissioners selected by the governor, and the tendency, as revealed in the Georgia, Florida and North Carolina commissions, appears to be running in favor of the elective system.

\section{Term of Office}

The practise was well-nigh universal in the early history of the commissions of removing a commissioner just at the time when he was beginning to get a fair insight into the intricate problems connected with his office and was entering upon a period of usefulness to the state. Georgia was the only conspicuous exception to the prevailing notion that from two to four years was long enough for a commissioner to hold office. Even now the people of the South are still too much inclined to think that if a man is of requisite age and is morally responsible, he is fully qualified to hold any public office. In a few of the states, then, the people appear to be of the opinion that there is no reason why a commissioner 
should be allowed to monopolize an office for a long term of years. There is scarcely an able commission in the North or West the members of which do not enjoy terms of at least six years, whereas in the South there are four states-Alabama, Florida, Kentucky and Mississippiwhere the commissioners are limited to terms of but four years. It is encouraging to note, however, that the southern commissioners are being retained in office for continually longer periods of time. Of the present Virginia board, the chairman has served for nine years and another member for eight years; of the present Georgia board, the chairman has served for eight years, and another member for nine years; of the present Tennessee board, the chairman has served for eleven years; of the present Florida board, the chairman has served for nearly fourteen years and another member for nine years; and of the present Louisiana board, the chairman has served for eight years.

\section{Technical Fitness}

There is a deplorable lack of requirements in the south as to the technical fitness of the commissioners. Only four states, " for example, provide for the presence on their commissions of experienced railroad men. The people and their representatives in the legislatures do not seem as yet to recognize the fact that commissioners with little or no special training for their peculiar duties cannot begin to cope with the perplexing problems that

The longest terms served have been those by commissioners Tram. mell (L. M.) of Georgia, 17 years; Tunstall of Alabama, and Hill of Virginia, 15 years; Burr of Florida, 14 years; Shorter of Alabama, 13 years; McNeill of North Carolina, and Caughman of South Carolina. 12 years; and Wallace of Georgia, deFuentes of Louisiana, Rogers of North Carolina, and Bonham and Duncan of South Carolina, 11 years.

' Florida, Georgia, South Carolina and North Carolina. 
come so steadily before the various boards for solution. They do not appear to have realized that the regulation of railroads, as well as of other public utilities, demands a high degree of expert knowledge. Effective and broad-minded regulation can never be carried out by boards composed solely of farmers, lawyers, merchants, and the like, no matter how good their intentions, nor how wide their knowledge of their own callings. The regulation of railroads is an increasingly scientific matter calling for the ever-enlarging employment of scientific knowledge. It is unfair, then, to expect that three commissioners, elected by the people with small reference to their qualifications-as is the case generally throughout the South-can meet the situation in the intelligent manner in which that situation is being handled in the more progressive states of the North and West. Since railroads are by far the most important public utility under supervision it follows that one commissioner, at least, should be a man with an expert understanding of matters relating to railroad transportation. Another commissioner should be a lawyer with a good knowledge of railroad and public utility laws. The third commissioner might well be a business man of wide experience and of sound common sense.

At any rate, if the states of the South as a whole wish to have efficient and intelligent regulation they must either provide for the selection of experts upon the various commissions, or they must see to it that commissioners are retained in office long enough to become tolerably familiar with the duties of their positions. There is no other way out of the unsatisfactory conditions that now prevail in the majority of the southern commonwealths. 


\section{Appropriation for Commission Expenses}

In no other sections of the United States are the salaries paid to the commissioners as small, on the whole, as those which the southern commissioners receive. With the exception of the Vermont commission there is not a commission in the entire country so poorly paid as the South Carolina board, while outside of North Carolina, Virginia, and West Virginia there is not a state in the South that pays its commissioners more than $\$ 3000$ a year (excepting the chairman). Compare these figures with the amounts paid by states in other parts of the country. For example, the commissioners of Colorado, Indiana, Kansas, Montana, Oklahoma and Oregon receive $\$ 4000$ a year; those of Nevada, $\$ 4,250$ (the chairman gets $\$ 5000$ ); those of Maryland, Washington and Wisconsin, $\$ 5000$; those of California and Ohio, $\$ 6000$; those of New Jersey, $\$ 7500$; those of Pennsylvania, $\$ 8000$; and those of New York, $\$ 15,000$ a year. High-grade men, as a rule, simply cannot be had at the small salaries which the states in the South are now paying. If these states desire the services of men with that specialized knowledge that is at present almost indispensable, they must go after them with offers of salaries-say, from $\$ 5000$ to $\$ 6000-$ which men of ability are able to obtain in private callings.

But the comparison is even more unfavorable to the South when the total amounts of the annual appropriations for commission expenses are taken into consideration. The latest figures available for the southern states are as follows: Alabama, $\$ 18,000$; Florida, $\$ 30,000$; Georgia, \$28,700: Kentucky, \$17,300; Louisiana, \$20,500 ; Mississippi, \$II,500 (approximate) ; North Carolina, $\$ 24,340$; South Carolina, $\$ 20,000$; Tennessce, $\$ 11$, 
400 ; Virginia, \$29,100; West Virginia, \$40,000. The average, then, is around $\$ 23,000$. What a feeble showing they make compared with the amounts that states in the North and the West are contributing ! ${ }^{1}$ In I9II, for instance, the appropriation in Minnesota was $\$ 35,000$; in Texas, $\$ 37,280$; in Arkansas, $\$ 64,000$; in Massachusetts, $\$ 64,912$; in Nebraska, $\$ 66,5$ II ; in Oklahoma, $\$ 73,000$; in Wisconsin, $\$ 99,819$; and in New York (for commissioners alone), $\$ 50,000$. Since then, it is safe to assume, appropriations have mounted considerably. Certain it is that the annual expenditures in states like Connecticut, Maryland, New Jersey, Ohio and Washington, are well over the $\$ 100,000$ mark. Why should Mississippi appropriate but one-seventh, or less, of Maryland's total, and why should Georgia fall so far behind Oklahoma?

The truth is that the southern commissions (with the sole exception of the West Virginia Public Service Commission) have never been supported by their respective states in any but a beggarly fashion. Just as various inspection laws, - as, for instance, those concerned with factories,- - have not been as effective as they were intended to be because of the lack of funds for proper and thorough inspection, so the railroad commission laws have not been enforced in the effective manner in which other states, like Wisconsin and California, have enforced theirs, for want of the machinery adequately to carry them out. There is but little use in enacting restrictive legislation and in conferring extensive authority upon a commission, unless that legislation and that authority are backed up and made a reality through ample financial resources. Laws prohibiting consolidations, for instance, 
have been almost a dead letter in the South, for the commissions have simply not had the money with which to ferret out and prosecute the numberless violations of the statutes that have occurred. The average southern commission of today is fortunate if it may boast of even a rate-clerk, let alone special counsel; while the provision of a consulting engineer or of an inspector is a luxury possessed by but a couple of the boards. If regulation is to be both effective and intelligent the commissioners must be men of special training and of more than ordinary ability; and they must be supported by competent staffs of engineers, inspectors, rate-experts, statisticians, accountants and the like. The work that has been laid upon the commissions in recent years in the way of supervision of all sorts of public utilities is now so technical in its aspects that any support short of what has been described inevitably means faulty and harmful regulation.

There is an imperative need, therefore, for a large increase in the annual appropriations provided for the support of the southern commissions. If Maryland can afford $\$ 75,000$ yearly for the maintenance of its commission, then why cannot Virginia, or North Carolina, or even Mississippi and Tennessee,-with their small allowances of less than $\$ 15,000$ a year, provide in an adequate fashion for their boards? There are many, of course,-and possibly they form a majority of the people of the South, who will object that taxes are now quite high enough, without having them increased in order to put more money at the disposal of a board already, in their opinion, well enough supported. Such persons forget that the additional amount exacted from them by taxation would be returned to them several times over in the fairer and more discerning methods of 
supervision thereby rendered possible. But if the thought of increased taxation is unbearable, resort may be had to the imposition of fees of one sort or another upon the corporations regulated. Very likely this would best be worked out by the adoption of the method now in force in Wisconsin, whereby a fee of one dollar is charged by the commission for every one thousand dollars, par value, of stock or bonds approved by it. Of course all fees are collected, not by the commissioners, but by the state treasury. Considerable revenue has been obtained in this way, since the corporations have found that the approval of the commission has inspired public confidence in the securities thus approved and has so boosted their market value as more than to cover the amount of the fee. There is therefore no valid reason why the members of the southern legislatures should not promptly grant such financial support to the commissions of their respective states as will enable them to carry out the provisions of the law in the manner in which they were intended to be executed.

\section{The Valuation of Railroad Properties}

To the discretion of the commissions is left the ascertaining of the value of the railroad properties in the various states. There are, in fact, but four or five states in the country which make such valuation mandatory upon their commissions. Hampered as the southern commissioners have been by niggardly appropriations, they have been able, on the whole, to do but little in this direction. The only comprehensive valuation so far made was that accomplished by the Virginia commissioners in the first years of the corporation commission's existence. It would certainly appear desirable for the commissions to make a valuation of at least all new construction, and of 
as much of the old as possible, and to make these valuations conclusive evidence in subsequent court proceedings. There is altogether too much expense and delay involved nowadays in court appraisals.

\section{Accounts}

Upon no one of the commissions in the South is it mandatory (as in a few states like Wisconsin and Kansas) to regulate the accounting practises of, and prescribe systems of accounting for, the railroads under its jurisdiction. All of the commissions have the power, however, to prescribe systems of accounting,-in which they follow the forms prepared by the Interstate Commerce Commission (a desirable feature of uniformity), - while most of them are endowed with authority to regulate the accounting practises of the railroads. It cannot be said, though, that this authority is of any great importance, since there is no provision in any state for the auditing of accounts. The commissions simply check up the reports submitted by the railroads, and this, naturally. results in a very unsatisfactory sort of publicity. There has been in the experience of all the commissions but one noteworthy auditing of a railroad's accounts, and that was an audit, undertaken by the Florida commission, of the books and accounts of the Louisville and Nashville. And yet the southern commissions are this time in excellent company, for there are less than five states in the Union that provide explicitly for the auditing of accounts.

\section{The Regulation of Capitalization}

There are but few states in the country (among them Wisconsin, New York, New Jerscy, Ohio, California, and Maryland) that have given their commissions jurisdiction 
over the matter of capitalization. It is not surprising, therefore, to find but one State in the south whose commission has authority to regulate the capitalization of the railroads. The Georgia law follows the New York statute rather closely in providing that no securities shall be issued to run for more than twelve months, except for certain specified purposes, and upon the approval of the commission. The duty is also laid upon the commission of seeing to it that the proceeds are expended in accordance with the law.

There are a number of defects in this law, as measured by the standard exemplified in the Wisconsin statute. For one thing, there is no prohibition of stock or scrip dividends, or of shareholders' privileged subscriptions and other refined forms of "melon cutting." Again, there is no provision forbidding the issue of capital stock at less than par, paid either fully in cash or in property at a valuation fixed upon by the commission. Further, the law throws the way open to overcapitalization by its failure to prohibit the capitalization of "good will" and the payment in securities for labor or services. Lastly, there is no requirement in regard to the amortization of that part of the indebtedness which cannot properly be charged to capital account.

As to whether general regulative authority over financial matters should be conferred upon the southern commissions which now lack that authority, there is certainly room for grave doubt. Of course a unified financial control by the national government is the logical way out in the growing conflict between state and federal jurisdictions. But until the proper measure of authority is conferred upon the Interstate Commerie Commission or other federal body it may, indeed, bis advisable for the states of the South to discard the 
passive policy to which they have clung so long, and to clothe the various commissions with power such as that now enjoyed by the Wisconsin board. The experience of some of the states has demonstrated that the protection of investors may readily be combined with fair dealing to the railroads. On the other hand, if the powers of the commissions are to be increased in this way there must be provision, at the same time, for such a change in the personnel of the majority of the commissions as will guarantee just treatment to the railway carriers. If the control over capitalization is to be taken from the roads and lodged in the commissions, it must be placed in the hands of men who are both expert and disinterested, and in whom, therefore, the railroads, as well as the people, may justly repose their confidence.

\section{Rates}

The two duties of primary importance laid upon the commissions in respect to the subject of rates have been the fixing of reasonable rates and the elimination of that greatest of railroad evils-discrimination. With regard to the latter, the evidence clearly shows that the efforts of the commissioners, on the whole, have been successful. Excepting Kentucky, fluctuations in intrastate rates appear to have been reduced to a minimum. In fact, the greatest good achieved by the various boards has probably been the securing of relatively stable and uniform rates throughout each state. Comparatively few cases of discrimination (with the exception, always, of Kentucky) now come to the attention of the commissions, and they unite in declaring that this abuse seems to have been pretty well stamped out. And little wonder, in view of the authority of the majority of the boards to prescribe exact, and not alone maximum, 
rates, and in view, also, of provisions requiring the railroads not only to keep open for inspection at their offices schedules of every rate or charge made, but also to give notice to the commissions of intended changes in the existing schedules. And yet, as the chairman of the Virginia commission truly says, "Until human nature and human laws become perfect-discriminations will always exist in greater or less degree." No sensible person acquainted with the chaotic business conditions that existed in each state prior to the establishment of the commissions would deem it advisable to invite a return of those conditions through the abolition of these boards.

With reference to the prescribing of reasonable rates and fares, not so much success can be said to have attended the efforts of the southern commissions. They are empowered to fix "reasonable and just" rates and classifications (Kentucky excepted); they may order joint rates, and commodity and other special rates; and in South Carolina the commission may establish basing points. The predominant principle emphasized by the law-makers has been that of "reasonableness." But what is to be understood by "reasonable"? The courts, unfortunately, do not define the term. The commissioners, then, have had to resort to various principles which have been recognized elsewhere in the fixing and classification of rates. The two basic principles are, of course, the "value of the service" and the "cost of the service" doctrines. Numerous illustrations of both doctrines are scattered through the pages of annual reports. It has been very customary, for example, to put ordinary soap in one class, and fancy soap in a higher class. Since the expense of haulage is the same to the railroads, be the soap common or fancy, it is indisputable 
that the commissioners have thus placed different kinds of soap in different classes because fancy, is more valuable than common soap. The "cost of the service" doctrine is illustrated, on the other hand, in the rates fixed for the transportation of butter. It has been customary for the boards to put butter carried in boxes or kegs in a lower class then butter transported in a fancier way as, for instance, in crocks, since the cost of carriage is more expensive in the latter than in the former manner.

It is impossible to say to which principle the commissions, as a whole, have attached the more importance. No one doctrine appears to have been consistently and exclusively followed by any of the boards. The commissioners report, time and time again, that various circumstances have entered into their calculation in the making of "reasonable" rates. The only definite impression left in the mind of one who studies their reports is very likely to be-however unfortunately-that the commissions have deliberately sought to protect the commerce of their respective states by squeezing the railroads as hard as the courts would permit. Every commission, without exception, has selfishly endeavored to promote the welfare of the people of its own state at the expense of those of adjoining states. Intrastate rates have only too often been reduced by commissions with the sole purpose of thereby preserving state markets for state trade, in utter disregard, necessarily, of discriminations thus practised against the trade of other states.

The widespread reduction of rates and fares in the past decade, especially, has undoubtedly done serious injustice, in many cases, to the railroad carriers. There was no good reason why some of the commissions should go to the extreme of applying to the sparsely populated South, rates similar to those under which the railroads of the 
North, with their dense passenger traffic and heavy freight tonnage, were operating. A few of the commissions, to their credit, acknowledged in due time that they had gone beyond the bounds of reasonableness (like the Virginia commission), and made such restitutions to the roads as they could, in the shape of increased charges.

Many of the southern roads (such as the Louisville and Nashville, the Atlantic Coast Line, and the Norfolk and Western) have continued to operate under the reduced rates without experiencing a serious falling-off in their net earnings. These are the carriers, chiefly, whose traffic is densest and whose margin of safety, due to conservative financiering, has generally been adequate. Other companies, however, (of which good examples are the Southern Railway, the Seaboard Air Line, and the Atlanta, Birmingham and Atlantic), have found even moderate reductions by commissions and legislatures so oppressive that they have been forced to practise the greatest economies to avoid financial disaster. A few of them, indeed, have gone into the hands of receivers, - not as the result of the acts of commissions alone, but they were still more or less hurried along the path to bankruptcy by ill-timed reductions.

From the very beginning of commission regulation in the South, the trouble has been that the various commissioners have had to grope almost entirely in the dark in their endeavors to prescribe "reasonable and just" rates. Many of them have frankly confessed that even after extensive investigations they were not prepared to do more than to guess at what should be done in the way of at1aining "reasonableness" in the fixing of rates. The majority of the commissioners, handicapped as they have been by the want of appropriations for the auditing of the railroads' accounts, have not had the right sort of 
data to work with. Lacking the information that a careful audit would bring to light, they have been continually at sea as to the true financial condition of the railroads under their jurisdiction. It is little wonder, then, in spite of the honest intentions of the commissioners, that many instances of grave injustice have been the consequence of such haphazard methods of prescribing "reasonable" rates.

What is imperatively needed in the South is such an appropriation for railroad commission expenses by the various states as will permit of the working-out of definite and scientific methods similar to the cost system of the Wisconsin commission. The "cost of the service" system, until very recently believed unworkable by the great majority of railroad managers, has been proved by that board to be the fairest method in existence for the determination of the reasonableness of rates, and has been accepted by the Interstate Commerce Commission, and, in a much modified form, by several of the states (including Virginia, North Carolina and Georgia of the southern commonwealths). The Wisconsin board, in brief, has recognized two predominating factors in the making of reasonable rates, namely, the proper classification of the commodities carried, and the cost of the service per unit of transportation. In the classification of freight the value of the article transported has, quite justly, been given primary consideration. As regards the cost of the service, freight and passenger expenses have been apportioned between (a) terminal expenses and (b) the cost of movement between terminals. The elements, for example, that have been studied in the second of these divisions are (1) the loading of commodities, (2) the density of the traffic, (3) the weight of the article in proportion to bulk, (4) the distance carried, 
and (5) the risk or liability to damage. The cost system, in short, has been made to rest, as it should, upon facts derived from the operation of the railroads, and has been successfully established in Wisconsin by a very elaborate and painstaking system of calculations. So efficacious has the cost system proved itself and so palpably fair to both the railroads and the people, that not even once has the commission suffered a reversal in the courts when attacked as to the reasonableness of any of the rates which it has promulgated. A sorry contrast, indeed, between the results of scientific rate-making in Wisconsin and the consequences of mere guess-work, as a whole, in the South, where the railroads have good reason to doubt the fairness of the rates and fares under which they have been operating so long.'

\section{Court Review}

Final determination of the questions that come before the state commissions of the South must be vested in some sort of body, and it would seem but fair that the determination be made by the tribunal best qualified to render the final decision. The ideal railroad or corporation commission,-an ideal which the Wisconsin Railroad Commission approaches as closely as any commission in the United States and more closely, in fact, than any of the southern commissions, - would be the fittest agency of government to which to entrust the ultimate solution of perplexing railroad problems. Such a board would be fully as impartial and judicious as the courts are today, and far more expert than any other governmental body; its sources of information would be as complete as could

${ }^{1}$ Holmes, The Regulation of Railroads and Public Utilities in Wisconsin, pp. 110, 115, 122, 139 . 
reasonably be desired; while its freedom from hampering technicalities would do away with the tremendous expense, the interminable delays, and the provoking uncertainty of present-day litigation. Only with respect to the two questions as to the exceeding of its authority or as to its extra-legal procedure should the decisions of such a commission be reviewable by a competent court. Its findings as to facts should otherwise be absolutely final.

Unfortunately, however, the people of the United States appear to view with equanimity the long established doctrine of judicial control over the decisions of administrative bodies. The utmost that can be accomplished at the present time, therefore, is, first, to make the state commissions as impartial and expert as possible, and then to provide that the decisions of those bodies shall be, as nearly as possible, conclusive. It will be well worth while to ascertain what, if anything, has been done in the South, toward the hastening of the final determination of cases which come before the commissions.

I. In Virginia and West Virginia the power of review over the commissions' orders is very wisely confined to the highest court of each state. In this way a great deal of time and expense is saved, for in important cases the decisions of lower courts are almost sure to be appealed to the court of last resort. But in the entire country there are less than ten states that provide for this desirable limitation of the power of review. Alabama and Georgia afford some relief in the requirement that a suit to vacate an order of the commission may be prosecuted in a court, alone, of the county in which the state capital is situated.

2. In some states (like New Jersey and Washington) 
the decisions of the state commission may be reviewed by writs, only, of error or certiorari; in others (like Oklahoma, Virginia and West Virginia), by appeal alone. The great advantage of either of these methods lies in the fact that a new trial, with its attendant delays and expenses, is thereby out of the question. In the other nine states of the South, then, the courts do not get jurisdiction until either the commission brings a suit to enforce an order or to recover a penalty, or an aggrieved party starts an action to set aside an order of the commission. Given commissions with an expert and impartial membership, there is no excuse for the existence of such costly and antiquated modes of obtaining jurisdiction by courts.

3. Very desirable are provisions which set a period of limitation within which suits to set aside or modify the commission's orders must be brought. And yet conditions in the South, in this respect, are not at all satisfactory, for some states (Georgia, Kentucky, South Carolina and Tennessee) have neglected to set any period of limitation at all. In other states the period is entirely too long. Florida, for example, grants four years of grace. Mississippi and Virginia grant six months; Louisiana, three months; Alabama and West Virginia, thirty days; while North Carolina sensibly limits the period to ten days. The usual time throughout the South in which appeals from an inferior to a superior court must be made is thirty days. ${ }^{x}$

4. Six of the states give various kinds of preference to railroad and public utility cases, in the desire thus to hasten their final determination. Alabama and North Carolina give such cases precedence over all others except

${ }^{1}$ Ten days in Louisiana and North Carolina. 
criminal cases; Florida, over all except habeas-corpus proceedings ; Virginia, over all except habeas-corpus and commonwealth cases; West Virginia, over all except the correction of assessments; and Louisiana and Tennessee, over all other cases whatsoever. The remaining five states would do well to concede similar privileges.

5. Every state, with one exception, confers upon its courts (in Virginia and West Virginia, the supreme court alone) the power of passing upon the reasonableness and legality of its commission's orders. That exception, strange to say, is Mississippi, which goes half way and provides that the supreme court may set aside an order of the commission in the event, only, that the commission has exceeded its jurisdiction in the making of such order. Most of the states declare the findings of their commissions to be prima facie valid, so that the burden of proving that the order is unlawful and unreasonable is upon the party attacking the commission's order. But this is by no means enough, for the courts have no business to inquire into anything but the questions of law involved in a particular case. It would be a great step forward for any state to follow the example set by California and Vermont-and, in part, by Mississippiand to make the findings of its commission absolutely conclusive as the facts.

6. A favorite device with railroads that are attacking the rulings of a state commission is to withhold important evidence in the development of their cases before the commission for the purpose of introducing it in court upon appeal, relying upon the new evidence to secure a reversal of the commission's decision. A number of the states' have greatly lessened this practice by the enact-

' Florida, Louisiana, Mississippi, South Carolina and Tennessee. 
ment of legislation compelling the railroads fully to develop their cases before the commission, under penalty, otherwise, of having the entire record referred back by the court, in case of appeal, to the commission for further hearing. An even more effective way of shutting off unnecessary litigation would be to require-as is already required by some of the northern and western states, like California, Oklahoma, Vermont and Washington, and also, recently, by West Virginia-that the court, upon appeal, should be confined solely to the evidence certified to it by the commission.

7. Finally, several miscellaneous provisions may be noted which have for their end the discouraging of wearisome litigation. Louisiana has a rather drastic statute according to which corporations under the jurisdiction of the commission are subjected to a penalty of from $\$ 10$ to $\$ 50$ a day, accruing from the date of an order, in any case where such order, upon appeal, is pronounced legal and valid by the court of review. In North Carolina, Virginia, and West Virginia, no suspension of the commission's order may be had until the petitioning railroad has first filed a bond with the commission, sufficient in amount and security to insure the prompt refunding of all charges which such company may collect, pending the determination of the appeal, in excess of those authorized by the final decision of the court of last resort. North Carolina and Virginia add the excellent requirement that the appealing company must keep such accounts as will show the names and addresses of persons to whom overcharges will be refundable in case the company's charges are not sustained by the court.

In a majority of the southern states, then, a simple appeal by the railroads to the courts operates to stay an order of the commission. And further, it is a ridicu- 
lously easy matter for a railroad to file a suit for the setting aside of an order. It is only necessary for the carrier to set forth in a petition that the order of which it is complaining is unreasonable, and ask that it be set aside. The road does not even have to file an affidavit in support of whatever allegations it may make. Such a condition of affairs should be regarded as intolerable by every self-respecting commonwealth in the South, and efforts should be made at once to remedy a situation that is exactly to the liking of the railroads. For the carriers, well knowing that to postpone an order of a commission for a length of time is nearly equivalent to. foiling it altogether, will never cease their resort to litigation for the sole purpose of delay, until all the states have made the pursuance of such a course as unpleasant and difficult as is now the case in North Carolina and Virginia. 


\section{CHAPTER XIX}

\section{Conclusion}

Somewhat over a decade ago, a gentleman of prominence in Georgia expressed himself as follows regarding the commission of that state :

The commissioners draw their salary and their breath. They are, as a rule, the servile tool of the railroad corporations, and have been of no service whatever to the people. They have allowed the grossest extortion to be practised against the peach growers, the melon growers, lumber dealers and others, without lifting a hand in their defence. ... The railroad commision amounts to nothing more than a pretence, a sham, an imposition on the taxpayers, and an insidious prop to the present system of corporative robbery. ${ }^{1}$

These words of censure were uttered at a time when the most serious abuses of the railroad systems were still far from unchecked, and when it was a fair question, indeed, whether the majority of the southern commissions had not done more harm than good. Unjust discriminations had been by no means eliminated, the inflation of capitalization was a prevalent practise, unlawful combinations and consolidations were still flourishing, railroad lobbies were pursuing their nefarious work of bribery and corruption, shippers were far from standing upon an equality, and, in brief, the equality and justice that both federal and state laws were striving to secure had fallen lamentably short of realization.

'Quoted in Parsons, The Railways, the Trusts, and the People, p. 234. 
Such a picture as that drawn by the Georgia gentleman would be greatly exaggerated at present, however, for the evidences of advance in the South, as in the United States in general, are too conclusive to admit of any refutation. The past ten or fifteen years have witnessed an almost general eradication of the crude theories of railroad management under which so many railroad officials so long labored. The railroad men of the country, as a whole, - as probably the great majority of them have been for decades past-are now sincerely desirous of keeping in consideration the goal of common prosperity, and of conforming to the legitimate demands of public interest. The large and well-managed corporations of the South, as a rule, show a most commendable readiness to co-operate with the commissions in their work, so that by comparison with former years there may be said to be but remarkably little friction between the railroads and the various boards. The commissioners have long since discovered that by "bringing the complainants and the railway managers face to face in the presence of, and under the direction of, the commission " judicial hearings can be avoided in most instances, and that ordinarily "such relief as is just and proper can be secured without the delays and expense of litigation." : The comparatively few cases of failure to co-operate that do arise, come generally from small companies operated by officials ignorant of the law.

It is a matter for regret, however, that in the performance of their functions the commissioners of the various states still seem disposed to guard the interests of the industries of their respective commonwealths more jealously than a sense of justice would demand. The

'Report of Virginia Corporation Commission, p. 12. 
majority of the commissioners appear not to have heeded the admonitions of the Interstate Commerce Commission and the United States Supreme Court in the Schreveport case: if one may judge from a perusal of recent reports, the uppermost thought in their minds seems to be even yet so to lower intrastate rates in comparison with corresponding interstate rates and the intrastate rates of other states as to favor their own jobbers and producers at the expense of those of adjoining states. The consequence is a discouraging lack of consistency in the policies of the different states.

The continual growth of interstate commerce, of course, is steadily diminishing the importance of the state commissions so far as railroads are concerned. It may safely be asserted that at least three fourths of southern trade is moving in interstate and foreign commerce, so that the jurisdiction of the commissions has now become so limited as to make their work and influence relatively insignificant. And with the ever rising proportion of interstate commerce to total commerce it seems certain that the role which the commissions are playing with reference to railroad regulation is to become of less and less importance.

As between regulation by the state commissions of the South and by the Interstate Commerce Commission, it is indisputable that comparison is greatly in favor of the latter. Regulation by the federal board, in spite of the complaints and criticism heaped upon it, has been, on the whole, both expert and intelligent. Regulation by the southern commissions has been neither. Since the principle of regulation has apparently come to stay, it is entirely pertinent to ask what remedy, if any, may be invoked. If the southern states shall continue their "penny-wise, pound-foolish" policy of compelling their 
commissioners to administer the law on appropriations so beggarly small that intelligent and expert regulation is entirely out of the question, and if the commissioners themselves do not promptly adopt a broad-minded policy in connection, especially, with those large systems of railroad, like the Southern Railway, the Illinois Central and others, which are now subject to the conflicting policies of nearly a dozen states, it will be but fair to demand that state regulation be brought into complete harmony with federal regulation. The next step in the history of the regulation of the railroads may very possibly be the federal incorporation of all railroads transacting an interstate business, and the consequent subjecting of all state supervision to review by the Interstate Commerce Commission. 


\section{APPENDIX \\ RaIlRoad COMmissioners}

VIRGINIA

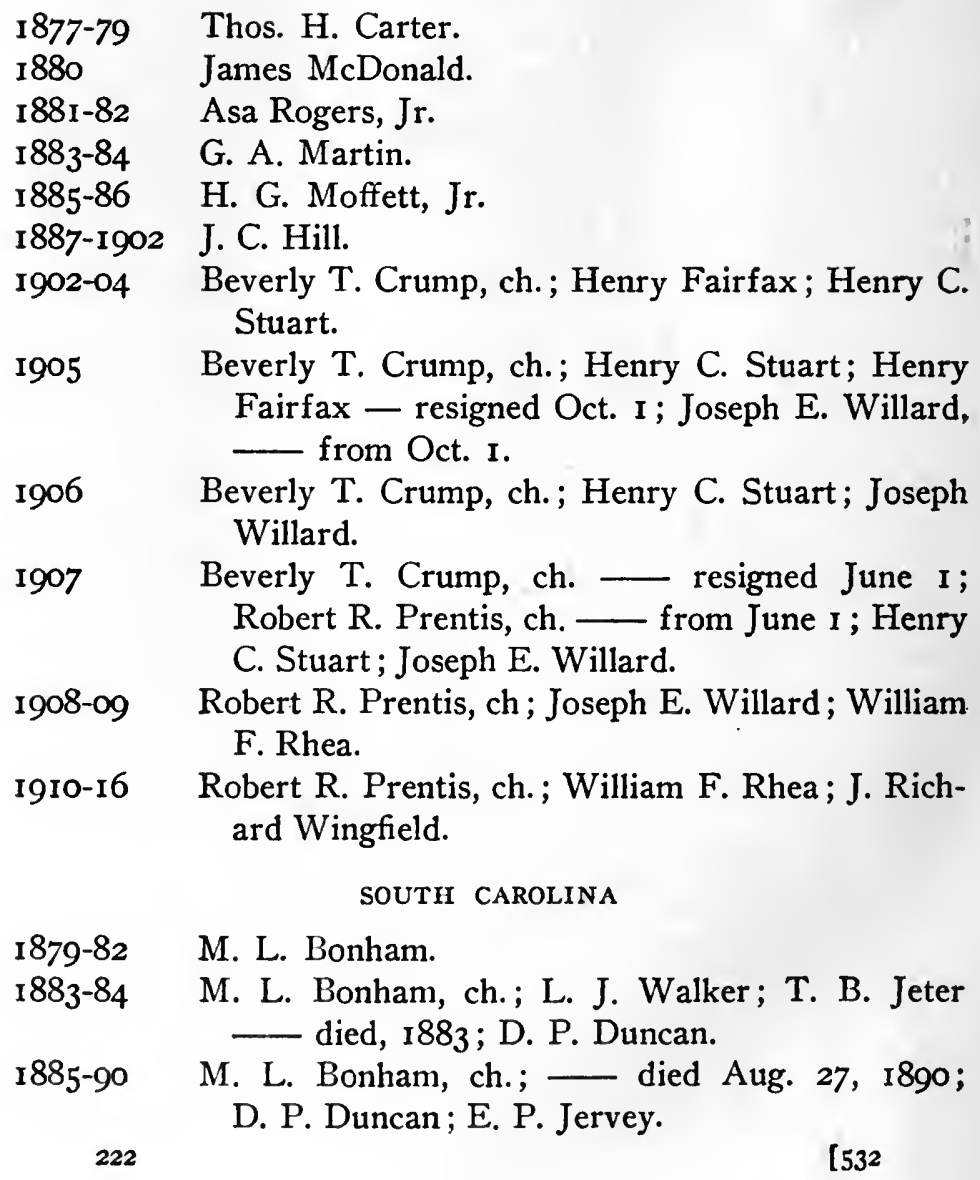

1908-09 Robert R. Prentis, ch; Joseph E. Willard; William F. Rhea.

1910-16 Robert R. Prentis, ch.; William F. Rhea; J. Richard Wingfield.

\section{SOUTH CAROLINA}

$1879-82$ M. L. Bonham.

1883-84 M. L. Bonham, ch.; L. J. Walker; T. B. Jeter died, 1883 ; D. P. Duncan.

1885-90 M. L. Bonham, ch.; - died Aug. 27, 1890; D. P. Duncan; E. P. Jervey. 
1891-92 D. P. Duncan, ch.; E. P. Jervey ; H. R. Thomas.

$1893-94$

D. P. Duncan, ch.; H. R. Thomas; Jefferson A. Sligh.

$1895-98$ W. D. Evans, ch.; H. R. Thomas; J. C. Wilborn.

1899-1900 W. D. Evans, ch.; J. C. Wilborn; C. W. Garris.

1901-02 J. C. Wilborn, ch.; C. W. Garris; J. H. Wharton.

1903-04 C. W. Garris, ch.; J. H. Wharton; B. L. Caughman.

1905-06 J. H. Wharton, ch.; B. L. Caughman; J. H. Earle.

1907-10 B. L. Caughman, ch.; J. H. Earle; J. M. Sullivan died Nov. 2, I910; John G. Richards, Jr. _ from Nov. 26, 1910; J. H. Earle was chairman during 1909-10.

1911-15 B. L. Caughman, ch.; John G. Richards, Jr.; G. $\mathrm{McD}$. Hampton.

1916 G. McD. Hampton, ch.; John G. Richards; Frank W. Shealy.

\section{GEORGIA}

1879-82 James M. Smith, ch.; Campbell Wallace; Samuel Barnett.

1882-86 James M. Smith, ch.; Campbell Wallace; Leander M. Trammell.

1886-90 Campbell Wallace, ch.; Leander M. Trammell; Alex S. Erwin.

1890 Leander M. Trammell, ch.; Alex S. Erwin; James W. Robertson.

1890-91 Leander M. Trammell, ch.; Alex S. Erwin; Virgil Powers.

1891-93 Leander M. Trammell, ch.; Virgil Powers; Allen Fort.

1893-95 Leander M. Trammell, ch.; Allen Fort; G. Gunby Jordan.

1895-97 Leander M. Trammell, ch.; Allen Fort; Thos. C. Crenshaw.

1897-99 Leander M. Trammell, ch.; Thos. C. Crenshaw; Spencer R. Atkinson. 
I899-190I Thos. C. Crenshaw, ch.; Spencer R. Atkinson; J. Pope Brown.

I90I-03 Spencer R. Atkinson, ch.; J. Pope Brown; G. Gunby Jordan.

1903-04 J. Pope Brown, ch.; J. Warner Hill; Jos. M. Brown.

1904-06 J. Warner Hill, ch.; Jos. M. Brown; O. B. Stevens. 1907 S. G. McLendon, ch.; H. Warner Hill; O. B. Stevens; George Hillyer; Fuller E. Callaway.

1908 S. G. McLendon, ch.; H. Warner Hill; O. B. Stevens; George Hillyer; Chas. M. Candler.

I909-10 H. Warner Hill, ch.; O. B. Stevens; George Hillyer; Chas. M. Candler; Joseph F. Gray.

1911-16 Chas. M. Candler, ch.; George Hillyer; Joseph F. Gray; Paul B. Trammell; James A. Perry.

\section{KENTUCKY}

1880-82 J. Fletcher Johnston, ch.; C. H. Rochester; C. E. Kinkaid.

I882-84 D. Howard Smith, ch.; Willis B. Machen; Wm. Beckner.

1884-88 J. P. Thompson, ch.; John D. Young; A. R. Boone _ died Jan. 27, 1886; I. A. Spaulding —from Jan. 27, 1886.

I888-92 I. A. Spaulding, ch.; W. B. Fleming; John P. Hager -resigned?; George H. Adams appointed to fill unexpired term.

I892-95 C. C. McChord, ch. — resigned May 24, 1892; James M. Saunders — from May 24, I892; Urey Woodson; Charles B. Poyntz.

1895-99 John C. Wood, ch.; H. S. Irwin; J. F. Dempsey.

I899-I903 C. C. McChord, ch.; John C. Wood; J. P. Dempsey.

1903-1907 C. C. McChord, ch.; — resigned, Dec. 8, 1903; W. P. Walton from Dec. 8, 1903; McD. Ferguson; A. T. Siler. 
$1907-09$

A. T. Siler, ch.; Med. Ferguson - died June 17. 1909; John P. Haswell, Jr. _ from June 17, 1909, to Dec. 1, 1909; Lawrence B. Finn from Dec. I, 1909; L. P. Tarlton.

1909-16 Lawrence B. Finn, ch.; W. F. Klair; H. G. Garrett.

\section{ALABAMA}

188 r-84 W. S. Bragg, pres.; Jas. Crook; Chas. P. Ball.

1884-92 H. R. Shorter, pres.; L. W. Lawler; W. C. Tunstall.

1892-95 H. R. Shorter, pres.; W. C. Tunstall; ?? Holtzclaw _ died July 18, 1893 ; Willis G. Clark from July 18,1893 .

1895-97 H. R. Shorter, pres.; Harvey E. Jones; Ross C. Smith.

1897-99 James Crook, pres.; Harvey E. Jones; Ross C. Smith.

1899-1901 James Crook, pres.; A. E. Caffee; Osceola Kyle. 1901-03 John V. Smith, pres.; A. E. Caffee; W. C. Tunstall.

1903-05 John V. Smith, pres.; W. T. Sanders; W. C. Tunstall.

1905-07 Missing.

1907-14 Charles Henderson, pres.; IV. D. Nesbitt; Jno. G. Harris.

1914-16 Sam P. Kennedy, pres.; B. H. Cooper; S. P. Gaillard.

\section{TENNESSEE}

1883-84 Missing.

$1897-98$ E. L. Bulloch, ch.; N. H. White; F. M. Thompson. 1899-1904 N. W. Baptist, ch.; J. N. McKenzie; Thos. L. Williams; J. N. McKenzie was chairman during $1903-04$.

1905-06 B. A. Enloe. ch.; J. N. McKenzie - died Aug. 3, 1906: N. H. White-from Aug. 2, 1906; Thos. L. Williams. 
1907-15 B. A. Enloe, ch.; Frank Avent; Harvey H. Hannah. I915-16 B. A. Enloe, ch.; Harvey H. Hannah; George N. Welch.

\section{MISSISSIPPI}

1884-86 Missing.

1886-87 J. F. Sessions, ch.; J. C. Kyle; Wm. McWillie.

I887-89 J. F. Sessions, ch.; J. C. Kyle; Walter McLaurin.

I889-95 J. F. Sessions, ch; ; J. C. Kyle; J. H. Askew. In I89I the title of "chairman" was changed to that of "president."

I895-99 J. J. Evans, pres.; J. D. McInnis ; M. M. Evans. I899-I903 J. D. McInnis, pres. ; A. Q. May; J. C. Kincannon. 1903-07. S. P. McNair, pres.; J. C. Kincannon; R. L. Bradley.

1907-09 F. M. Lee, pres.; John A. Webb; W. R. Scott.

I909-I I John A. Webb, pres.; W. R. Scott; F. M. Sheppard.

I9II-I6 F. M. Sheppard, pres.; Geo. R. Edwards; W. B. Wilson.

\section{FLORIDA}

I887-9I G. G. McWhorter, pres. ; Enoch J. Vann; William Himes.

I897-98 R. H. M. Davidson, ch.; H. E. Day; J. M. Bryan. I 899-I900 H. E. Day, ch.; J. M. Bryan; J. L. Morgan.

190I-02 H. E. Day, ch. — resigned Oct. I, I902; R. Hudson Burr - from Oct. I, I902; J. M. Bryan; J. L. Morgan (chairman from Oct. I, I902).

I903-06 Jefferson B. Browne, ch.; J. L. Morgan; R. Hud son Burr.

1907-08 R. Hudson Burr, ch.; J. L. Morgan; N. A. Blitch. I909-I6 R. Hudson Burr, ch.; N. A. Blitch ; R. C. Dunn. 
NORTH CAROLINA

1891-94 James W. Wilson, ch.; T. W. Mason; E. C. Beddingfield.

1895-97 James W. Wilson, ch.; E. C. Beddingfield; C. O. Wilson.

1897-99 L. C. Caldwell, ch.; Jno. H. Pearson; D. H. Abbott. 1899 Franklin McNeill, ch.; E. C. Beddingfield; Sam L. Rogers - ousted by N. C. Supreme Court Nov. 22 ; D. H. Abbott - from Nov. 22.

1900-02 Franklin McNeill, ch.; Sam L. Rogers; D. H. Abbott.

1903-08 Franklin McNeill, ch.; Sam L. Rogers; E. C. Beddingfield.

1909 Franklin McNeill, ch.; Sam L. Rogers; B. F. Aycock.

1910 Franklin McNeill, ch.; Sam L. Rogers; Henry C. Brown.

1911 Franklin McNeill, ch.; W. T. Lee; Edward L. Travis.

1912-16 Edward L. Travis, ch.; W. T. Lee; George P. Pell.

\section{LOUISIANA}

1899-1906 C. L. de Fuentes, ch.; W. L. Foster; R. N. Sims —resigned April, I901; Overton Cade — from April 1901.

1906-08 C. L. de Fuentes, ch.; Overton Cade; J. J. Meredith.

1908-10 C. L. de Fuentes, ch.; J. J. Meredith; Shelby Taylor; Mr. Meredith was chairman during 1910.

1910-12 J. J. Meredith, ch.; Shelby Taylor; Henry B. Schreiber.

1912 Shelby Taylor, ch.; Henry B. Schreiber; B. A. Bridges.

1914-16 Shelby Taylor, ch.; B. A. Bridges; J. T. Michel. 
228

WEST VIRGINIA

19I3-I5 Virgil L. Highland, ch. _ resigned July ro, I91 3 ; J. S. Lakin-from July Io, I913 ; resigned July I7, 1913; Lee Ott,-from July I7, I913, chairman. Wade C. Kilmer; Charles H. Bronson; Howard N. Ogden.

I9I5-16 Elliott Northcott, ch.; Wm. M. O. Dawson; E. F. Morgan. 


\section{Noteworthy New Books}

\section{Priest: Germany since 1740}

By Grokce Mantson Prirst, Profanor of Germanic Languages and Literature in Priaceton University. $12 \mathrm{mo}, x \mathrm{x}+199$ pages, 81.25.

A brilliant historical account of the genesis of modern Germany. The chronicle includes one of the most interesting periods of Cierman history, from the time of the accessions of Maria Theresa and Frederick the Great down to William II and the teginning of the preseut was.

The hook in fully equipped with majs, a chronological table, genea. logies of leading ruling houser, bibliography, and index.

\section{Gettell: Problems in Political Evolution}

By Rarmonv Gettruh, Professor of Social and l'oltical Science, Am. herst College. 8vo, 400 pages, 83.00 .

An attempe to trace the formation and evolution of modern government. Among the many probiema consilered are:-the leading factors in political development; the origin of the state; relations of the state to the family, the church, industrial organizations and military organizations; the functions and prapose of the state: and the present tendencies in political evolution.

\section{Thallon: Readings in Greek History}

By IDa Carbron Tulalon, Assistant Professot of History in Vessat College. Sro, $x \times i x+6{ }_{3} 8$ pages, 2.00 .

This book comprises extracts translated from the Greek of the original sources, ranging from the time of Homet through the Battle of Chacronea. Students of history unacquainted with Greek can read in this volume not merely passages from the historians but translations of historical inseriptions, selections from the orators, and those passages from the dramatiss and poets which throw light on the history of the period to which they lelong.

\section{Hayes: British Social Politics}

By CARlrton Hayes, Assistant l'rofesor of Hisery la Columbia Uni. versity. $12 \mathrm{mo}, 5$ So pages, 31.75.

This volume deals with the secent work of social reform and working. class legislation in Great Britain. During the past seven years many important workingman's acts have been passed: workmen's compensaion, trade dispute, labor exchange, old.age pension, etc., accomplishing collectively a veritable revolution, though a comparatively peaceful one. Fiach of these is treated in a separate chapter aud in each case the act itself is given. An invalualle book not merely for historian, ant economist, but also for social worken and in. telligent, earnest citizens.

\section{GINN AND COMPANY BOSTON NEW YORK CHICACO LONDON}




\section{Studies in History, Economics and Public Law}

edited by the

\section{Faculty of Political Science of Columbia University}

VOLUME I, 1891-92. 2nd Ed., 1897. 396 pp. Price, cloth, \$3.50.

1. The Divorce Problem. A Study in Statisties.

by WALTer F. Willcox, Ph.D. Price, 75 cents.

2. The IIIstory of Tailf Adminiatration in the United States, from Colonial Times to the McKiniey Administrutive Bill.

By John Dean Goss, Ph.D. Price, \$1.00.

3. History of Munleipal Land Ownership on Manhat tan Island.

By Ggorge Ashion Black, Ph.D. Price, \$x.,0.

4. Finandal History of Massachnsetts.

By Charles H. J. Douglas, Ph.D. Price, \$2.00.

\section{VOLUME II, 1892-93. (See note on page 4.)}

1. The Economles of the Rnssian Village. By Isac A. Hourwich, Ph.D. (Out of print.) 2. Bankruptoy. A Study In Comparative Legislation.

By SAMUEL W. DUNSCOMB, Jr., Ph.D. (Not sold separately.)

3. Special Assessments: A Study in Municipal Finance.

By Victor RosmwatzR, Ph.D. Second Edition, 1898. Price, 81.00.

VOLUME III, 1893. 465 pp. (Sold only in Sets.)

1. *History of Elections in American Colonies.

By Cortland F. Bishop, Ph.D. Price \$2.00, cloth.

2. The Commerclal Pollcy of Encland toward the American Colonies.

By GBORGE L. BEER, A.M. (Not sold separately.)

VOLUME IV, 1893-94. $438 \mathrm{pp.} \mathrm{(Sold} \mathrm{only} \mathrm{in} \mathrm{Sets.)}$

1. Financial History of Virginia.

By William Z. RIPLEY, Ph.D. Price, 8 r.00.

2. "The Inheritance Tax.

By Max Wast, Ph.D. Second Edition, 2908. Price, 82.00 .

3. History of Taxation in Vermont. By Fredreick A. Wood, Ph.D. (Not sold separately.)

\section{VOLUME V, 1895-98. 498 pp. Price, cloth, \$3.50.}

1. Double Taxation in the United States.

2. The Separation of Governmental Powerg. By Francis Walker, Ph.D. Price, $\$ 1,00$, By William Bondy, LL. B., Ph.D. Price, \$r.,

3. Municipad Government in Mrichigan and Ohio.

By Drzos F. Wilcox, Ph.D. Price, \$r.0s.

VOLUME VI, 1896. 601 pp. Price, cloth, \$4.50; Paper covers, \$4.00. History of Proprietary Government in Pennsylvania. By William Rokert Surphard, Ph.D.

VOLUME VII, 1896. 512 pp. Price, cloth, \$3.50.

1. History of the Transition from Provincial to Commonwealth Government in Massachusetts. By Harry A. Cushing, Ph. U. Price, 82.00 .

2. * Speculation on the Stock and Prodnce Exchanges of the United States.

By HeNry Crosmy EMrry, Ph.D. Price, \$1.50.

VOLUME VIII, 1896-98. 551 pp. Price, cloth, $\$ 4.00$.

1. The strugglo between President .Johnson and Congress over Recon. struction.

By Charlis Linest Ciradsex, Ph. W. Price, \$r.00.

8. Recent Centralizing Tendencleg in State Edncational Administration. By William Clareice Webster, Ph.D. Price, 75 cents.

3. 'Tho Aboltion of Privateoring and the Declaration of Paris.

By Francis R. Stark, LL.13., Ph.D. Price, \$r.oo.

4. Public Administration in Massachusetts. The Relation of Central to Local Activity.

VOLUME IX, 1897-98. 617 pp. Price, cloth, \$4.00.

1. English Iocal Government of To-day. A Study of the Relntions of Central and Local Govornment.

2. German Wage Theorles. A IIIstory of thelr Development.

3. Tho Centralization of Administration in Now York State.

by James W. Crook, Ph.D. Price, \$1,00.

By JOHN ARCHIBALD Fairlix, Ph.D. Price, Ir.na 
VOLOMB X, 1898-99. 600 pp. Price, cloth, $\$ 3.50$.

3. Symputhetio Striken and Eymgathotjo Lovkoutw.

- Ithode Inlund and the Yormation of the Union.

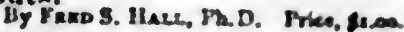

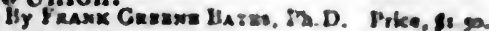

8. Centrallzed Adminlistration of Llanor Iawn in the American Common. woaltiw.

VOLOWE XI, 1899. 496 pp. Price, cloth, \$4.00; paper covers, \$3.50.

The Growth of Citlos.

By A mea funkis Wrekw, ith. D.

VOLUME XII, 1899-1900. 586 pp. Price, cloth, \$4.00.

1. Illstors and Funotlons of Contral Iabor Unlons.

By Wrusak Maxwere Bunke, M.D. Jike. gian

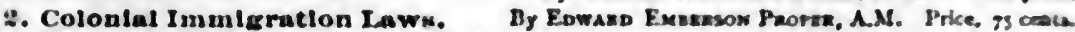

3. IIIstory of Mlltury Pension Legislation In tho United Binten.

By Wituam Hexk Gusiom, Th.D. Price, sica

4. IIntory of tho Theory of Boverolenty wince Ionwean.

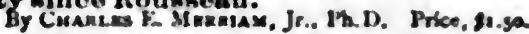

VOLUMEB XIII, 1901. 570 pagen. Price, cloth, \$4.00.

1. Tho Iogni Property Reletlous of Marriod Parties.

By issoon Loes, M.D. Prke, Is.sa

2. Polltical Natirimm In Now York State.

By Lours Dow Scasco, Mh. D. Price, fase.

8. Tho Iteconstruction of Goorria.

By Eowix C. Woover, M.D. Price, ficon

VOLUME XIV, 1901-1902. 676 pagen. Price, cloth, \$4.00.

1. Loyalim In Now York during the Amerionn Rovolution.

By Alexamber Clanexce Filuck, Ph. D. Price, L.,oa

8. The Foonomto Theory of It sk und Insurance.

3. Tho Fustorn Question: A study in Diplomacy.

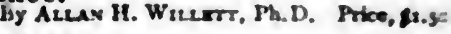

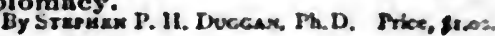

VOLU20: XV, 1902. 427 pp. Price, cloth, \$3.60; paper coters, \$3.00.

Crime in Its Relations to social Proeroses.

By Amruve Cleveramo HaLe, Ph. D.

VOLOUIE XVI, 1802-1903. 647 pp. Price, cloth, \$1.00.

1. The Past and Prosent of Commeroe in Japan,

By Yerano Kincosta, Ma.D. Prke, fl.ga

2. The Employment of Women in the Clothine Trnde.

8. The Centrilzation of Admintetracton in Ohlo. Dy Simura, P. Oarn, Ph.D. Price, H.ge

VOIJuE XVII, 1803. 635 pp. Price, cloth, \$4.00.

1. Contrallzing Tondenoles in the Adminiseration of Indiana.

Uy Willias A. Rawles, Pa.D. Price, R.:a

8. Prinolples of Juntioe in Taxntion. By Stamen F. Watom, Ph. D. Price, pea

VOLUWE XVIII, 1903. 753 pp. Price, cloth, \$4.50.

1. Tho Administration of Iown.

R. Tursot and tho $81 x$ Falcts.

By Hamolo Nautix Ruwax, Ph, D. Prioe, figa By Ronent P. Summexd, M. D. Price, fr.ga

8. Innover and Prumsla $1706-1803$. Dy Gur Sravtow Fons, Ph.D. Prke, pocas

VOLOWE XIX, 1903-1905. 688 pp. Price, cloth, \$4.00.

1. Josinh Tucker. Fconomtst.

By Walte linxest Cumx, Th.D. Price, ti ga

8. Itstory nnd Critleism of tho Inbor Theory of Vinlue In Fnellah Polltical Iconoruy.

8. Irade Unjons and the Inw In Now York.

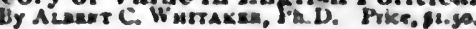

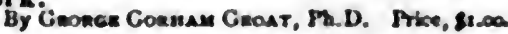

VOLUWE XX, 1904. 514 pp. Price, cloth, \$3.50.

1. The Omoe of the Justioo or the l'ence in Xegland.

By Cinales Atertix Dmand, Th.n. Prke. P1.ga

2. A IIIstory of Millary Government In Newiy Aequired Terrltory of the Inited staces.

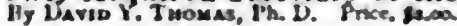

VOLOME XXI, 1004. 746 pp. Price, cloth, \$4.50.

1. Treatlos, thotr Maklng and Inforoement.

2. The Boclology of a Now Tork City Block.

By Samzer R. Cranaaze, Ph.D. Price, tr.ga

8. Pre-Malthualan Doctrincs or I'opulation.

By Twown Jean Josm, Mh. D. Price, it sea

liy Cunames F. Stamosumo, Ma.D. Prke, fo.ge 
VOLUHE XXII, 1905. 520 pp. Price, cloth, \$3.50; paper covers, $\$ 3.00$. The IIfstorical Development of the Poor Law of Connectiout.

HY EDFARD W. CAPEN, Ph.D.

VOLUME XXIII, 1905. 594 pp. Price, cloth, \$4.00.

1. The Economies of Land Tenure in Georgla.

By Enoch Marvin Banks, Ph.D. Price, \$1.00.

2. Mistake In Contract. A Study in Comparative Jurisprudence.

By Edwin C. McKeag, Ph.D. Price, $\$ 1.00$.

3. Combination in the Mining Industry. By Henry R. Mussey, Ph. D. Price, fr. .0 .

4. The English Craft Gullds and the Government.

By Strola Kramer, Ph.D. Price, $\$$ x.o.

VOLUME XXIV, 1905. 521 pp. Price, cloth, \$4.00.

1. The Place of Magle in the Intellectual History of Kurope.

By LVNN ThokNDike, Ph.D. Price, \$1.0.

2. The Ecclestastical Edicts of the Theodosian Code.

By Williais K. Bord, Ph.D. Price, 8x.00.

3. The International Position of Japan as a Great Power. By SEIjl G. HishiDA, Ph.D. Price, \$2.00.

VOLUMR XXV, 1906-07. 600 pp. (Sold only in Sets.)

1. * Munioipal Control of Publio Utllitles. By O. L. Pond, Ph.D. (Not sold separately.)

2. The Budget in the American Commonwealths.

3. The Finances of Cleveland.

By Eugrnz E. Aggra, Ph.D. Price, \$1.50.

VOLOME XXVI, 1907. 559 pp. Price, cloth, $\$ 4.00$.

1. Trade and Currency in Early Oregon. By James H. Gilnert, Ph.D. Price, \$7.00.

2. Lrither's Table Talk.

3. The Tolacco Industry in the United States.

By Meyer Jacoestein, Ph.D. Price, \$r.50.

4. Social Democracy and Population. By Alvan A. Tennry, Ph.D. Price, 75 cents.

VOLUME XXVII, 1907. 578 pp. Price, cloth, \$4,00.

1. The Economic Pollcy of Robert Walpole. By Norris A. Brisco, Ph.D. Price, 81.50.

2. The United States Steel Corporation. By Abraham Brqgiund, Ph.D. Price, \$r.5o.

3. The Taxation of Corporations in Massachusetts.

By Harry G. Frizdman, Ph.D. Price, \$1.50.

VOLUME XXVIII, 1907. 564 pp. Price, cloth, $\$ 4.00$.

1. Dewitt Clinton and the Orikin of the Spolls System in New York.

By Howard Lez McBain, Ph. D. Price, \$r.50.

2. The Development of the Legislatare of Colonial Virginia.

By Elmer I. Mir.lzR, Ph.D. Price, \$r.50.

VOLUME XXIX, 1908. 703 pp. Price, cloth, $\$ 4.50$.

2. New Hampshire as a Royal Province.

By Anne Bush Maclarar, Ph.D. Price, \$1.50. By Wir.tiam H. Fry, Ph.D. Price, \$3.00.

VOIUME XXX, 1908. 712 pp. Price, cloth, \$4.50; paper covers, $\$ 4.00$.

The Province of New Jersey, 1664-1738.

By Edwin P. Takser, Ph.D.

VOLUIIE XXXI, 1908. 575 pp. Price, cloth, \$4.00.

1. Private Freight Cars and American Rallroads.

2. Onio belore 1850.

By L. D. H. WrLD, Ph.D. Price, \$1.50.

By Romert E. Ciladdock, Ph.D. Price, \$1.50

3. Consanguinoous Marriages in tho American Popalation.

4. Adolphe Quetelet as 8tatisticlan.

By Gaokg B. Louis ARner, Ph.D. Price, 75 cents. By Frank H. Hanking, Ph.D. Price, \$1.25.

VOLUME XXXII, 1908. 705 pp. Price, cloth, \$4.50; paper covers, \$4.00. The Enforocmont of the Statutes of Laborers. By Brrtha Haven Putnam, Ph.D.

VOLUME XXXIII, 1908-1809. 635 pp. Price, cloth, $\$ 4.50$.

1. Factory I.eglslation in Maine.

2. Psychological Interpretations of society.

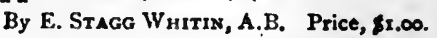

By Micharl M. Davis, JR., Ph.D. Price, \$2.00.

3. An Introduction to tho Sources relating to the Germanic Invasions.

by Carlton Hunteky Inyms, Ph.D. Price, \$r.5a. 
VOTUnas 20.0.TV, 1909. 628 pp. Price, clotb, 54.50.

1. [80] Transportation and Induetrial Derelopment in the Middle West.

9. (00] Bootal Keform ant the Ketormation.

8. [01] keeponalulily for Crime.

By Jacon Salwrk Schapino, Ph.D. Price. ss.eg.

VOLUME XOXV, 1909. 368 pp. Price, cloth, \$4.50.

1. [08] The Confliot orer the Judiolal Iowgre In the United states to 1670.

9. [08] A stady of the ropulation of Mantiattanville.

HY Howand bnowi Wooltrom, Ph.D. Price, fl.es.

o. [De] - Divoroe: $\Delta$ Beudy In sodal Canation.

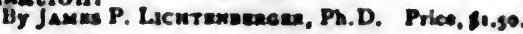

VOLUNE XXXVI, 1910. 642 pp. Price, cloth, \$4.00.

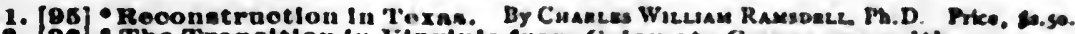
9. $\mid$ Dé $\mid$ - The Traneltion in Vireinia from Colony to Commonwealth.

By Cinalso Kansonll LuGlar, Ph. U. Price, 8r.go.

VOLOMIE XXXVII, 1910. 606 pp. Prico, cloth, \$1.50.

1. [87] etandards of Reasonablouess in Local Frelche I incrininations.

By Jowr Maunice CLaxx. Pa. U. Price, gs.os.

8. (88) Iecal Development In Colonial Magnachunetts.

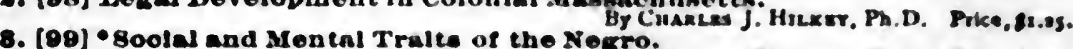

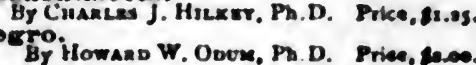

VOLUME XXXVIII. 1910. 463 pp. Price, cloth, \$3.50.

1. (100) The Pobllo Domatn and Domoorngy.

8. [101] Orcaniemio Theorles of the stete.

Rouser Tudon Hall, Ph D. Prica, saco.

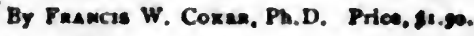

VOLUME XXXaX, 1910-1911. 651 pp. Prico, cloth, \$4.50.

1. [109] The Makine of the Halkan statge.

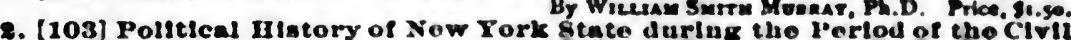
ivar.

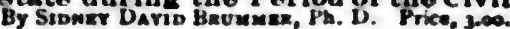

Vorones Xd, 1911. 633 pp. Prico, cloth, \$4.50.

1. [104] A Burvey of Conutitutlonal Jevelopment In China.

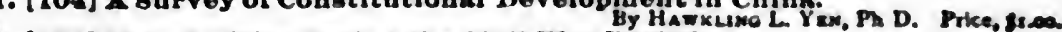

9. [105] Ohfo Polltion durine the Cirll War Perlod.

8. [106] The Territorial Hable of (dovernment under the State Con. Prce. ft.pg. By Alvand Zamrixcex Rewo, Ph.U. Price, Bs.75.

VOLUMde XII, 1911. 511 pp. Price, cloth, 33.50; paper covers, 83.00 . [107] Now Jersey ma n kloyul Provlnce.

By Edan Jacon Yanas, Pb. D.

VOLUME XIII, 1911. 400 pp. Price, cloth, 33.00; paper covers, 82.50.

[108] Attitude of American Conrtw in Labor Cames.

By Geonez Gomman Geout, Mh.D.

VOLUnes XIII, 1911. 633 pp. Price, cloth, \$4.50.

1. [109] •Industrlal Carses of Cougewelon of Popnlation In Now York City.

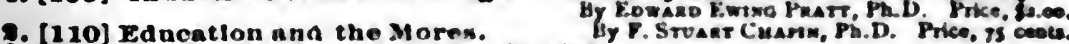
8. (111) The Britsuh Consule In the Contederncy.

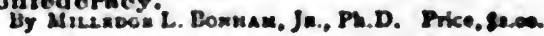

VOLUnass XITV and XIV, 1911. 745 pp.

Pyce for the two volumes, cloth, $\$ 6.00$; paper covers, \$5.00.

[118 and 118) Tho Economile l'rinclples of Confuclun and hin school.

By Cinz Huatuano, M.D.

VOLUME XIVI, 1911-1912. 623 pp. Price, clotb, \$4.50. -

1. (114) The Ricardian Soclallets.

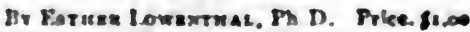

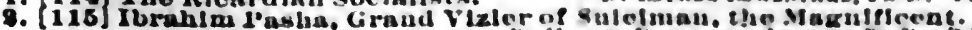

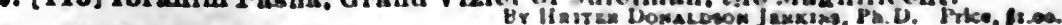

8. [1 16] -gyndicallsm In France.

4. [118] A Irooster villace.

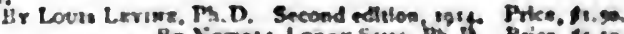

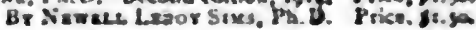


VOLUME XLVII, 1912. 544 pp. Price, cloth, $\$ 4.00$.

1. [118] The Polltics of Michigan, 1865-1878,

2. $\left[\begin{array}{ll}1 & 19\end{array}\right]$ *The United States Beet Sugar Industry and the Tariff. By Roy G. Braxey, Ph.D. Price, \$2.00.

VOLUME XLVIII, 1912. 493 pp. Price, cloth, $\$ 4.00$.

1. [120] Isidor of Sevillo.

2. [121] Progress and Uniformltyin Chlld-Labor Legislation.

By Ernkst Brehaut, Ph. D. Price, 82.00 . By William Fieldinc OGburn, Ph.D. Price, gr.75.

VOLUME XIIX, 1912. 592 pp. Price, cloth, $\$ 4.50$.

1. [122] British Radicalism 1791-1797.

2. [123] A Compretive study of the Law of Corporations. 3. [124] *The Negro at Work in New York City.

By Grorge E. Haynes, Ph.D. Price,\$1.25.

VOLOME L, 1911. 481 pp. Price, cloth, $\$ 4.00$.

1. [125] *The Splrit of Chlnese Philanthropy. Bv Yax Yur Tsu, Ph.D. Price, \$r.oo. 2. [126] "The Alien in China. BYVI. Kyuin Wrlington Koo, Ph.D. Price,\$2.50. VOLUME LI, 1912. 4to. Atlas. Price: cloth, $\$ 1.50$; paper covers, $\$ 1.00$. 1. [127] The Sale of Liquor in the South.

By Leonard S. Blakey, Ph.D.

VOLUME III, 1912. $489 \mathrm{pp}$. Price, cloth, $\$ 4.00$.

1. [128] *Provincial and Local Taxation in Canada.

2. [129] *The Distribution of Income. By Solomon Vingare, Ph.D. Price, 8r.5o.

3. $[130]$ *'The Finances of Vermont.

By Frank Hatch Streightoff, Ph.D. Price, 11.50. By Frederick A. WoOd, Ph.D. Price, \$1.00.

VOLUME LIII, 1913. 789 pp. Price, cloth, $\$ 4.50$; paper, $\$ 4.00$.

[181] The Civil Warand Reconstraction in Florida. By W. W. DAvis, Ph.D.

VOLUME LIV, 1913. 604 pp. Price, cloth, $\$ 4.50$.

1. [132] * Privileges and Immunities of Citizens of the United States.

.

2. [133] The Supreme Conrt and Unconstltutional Legislation.

3. [184] *Indian Slavery In Colonlal Timesy BLAine FREBMoors, Ph.D. Price, 81.00. United States.

By Almon Whegek Lauber, Ph. D. Price, $\$ 3.00$.

VOLUME LV, 1913. 665 pp. Price, cloth, $\$ 4.50$.

1. [135] *A Political History of the State of New York.

1. [135] A Politeal Fistory of the State of New York.

2. [186] "The Early Persecutions of the Christians.

By lemon H. Canmeld, Ph.D. Price, \$1.50.

VOLUME LVI, 1913, 406 pp. Price, cloth, $\$ 3.50$.

1. [137] Specnlation on the Now York Stock Exchange, 1904-1907.

By A L.GerNon ASHBURER USBORNe. Price, \$1.50.

2. [138] The Pollcy of the United States towards Industrial Monopoly. By OSWALO WhitMan KNaUth, Ph. L. Price, $\$ 2.00$.

VOLUME LVII, 1914. 670 pp. Price, cloth, $\$ 4.50$.

1. [130] "The Civil Service of Great Britain.

¿. [140] The Flnancial History of New York State.

By Robert Moszs, Ph.D. Price, \$2.00. By Don C. Sowrrs. Price, 82.50 .

VOLUME LVIII, 1914. 684 pp. Price, cloth, \$4,50; paper, $\$ 4.00$.

[14 1] Reconstruction in North Carolina.

VOLUME LIX, 1914. 625 pp. Price, cloth, \$4.50.

1. [142] The Development of Modern Turkey by means of its Pross.

1142]

2. [143] The Syston of Taxation in China, 1614-1911.

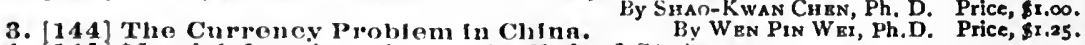

4. 145. Jewish innigrition to the United states.

By Samurl Josrah, Ph.D. Price, \$r.50. 




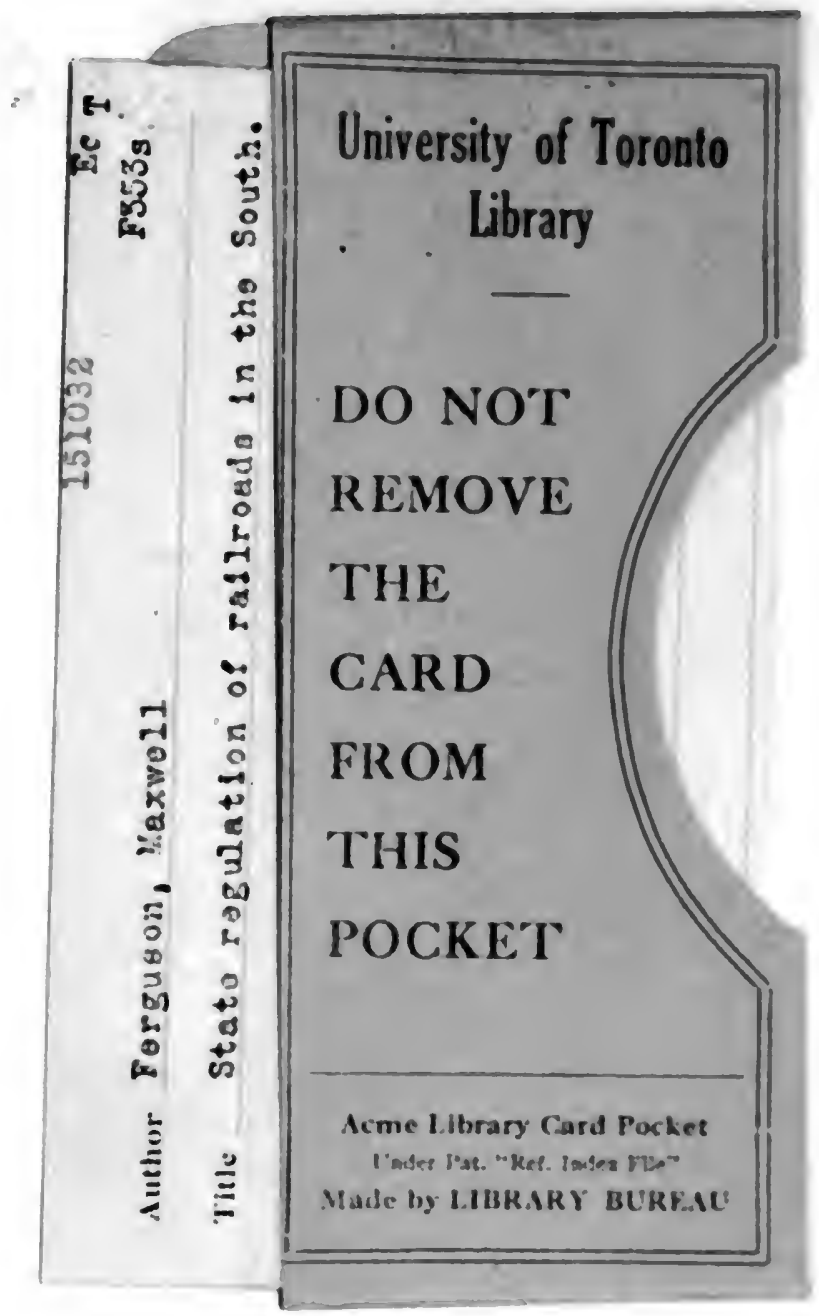


